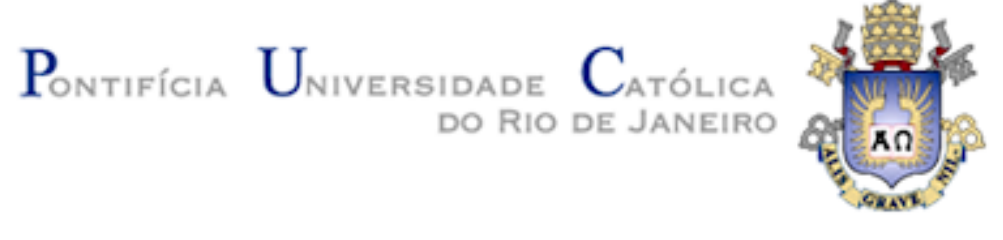

Alexandre dos Santos Silva

\title{
Rompendo em fé - As representações evangélicas nas narrativas de artistas contemporâneos brasileiros
}

Dissertação de Mestrado

Dissertação apresentada como requisito parcial para obtenção do grau de Mestre pelo Programa de PósGraduação em Literatura, Cultura e Contemporaneidade, do Departamento de Letras da PUC-Rio.

Orientador: Prof. Fred Coelho 


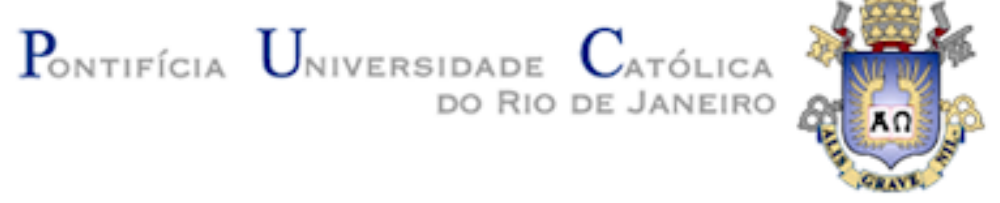

Alexandre dos Santos Silva

\section{Rompendo em fé - As representações evangélicas nas narrativas de artistas contemporâneos brasileiros}

Dissertação apresentada como requisito parcial para obtenção do grau de Mestre pelo Programa de PósGraduação em Literatura, Cultura e Contemporaneidade da PUC-Rio. Aprovada pela Comissão Examinadora abaixo.

Prof. Frederico Oliveira Coelho

Orientador

Departamento de Letras - PUC-Rio

Profa. Aline Leal Fernandes Barbosa

Departamento de Letras - PUC-Rio

Profa. Eliska Altmann de Carvalho

UFRJ

Rio de Janeiro, 28 de abril de 2021. 
Todos os direitos reservados. A reprodução, total ou parcial, do trabalho é proibida sem autorização do autor, do orientador e da universidade

\section{Alexandre dos Santos Silva}

Graduou-se em Marketing na UVA (Universidade Veiga de Almeida) em 2008. Desenvolve pesquisas e projetos no âmbito das artes visuais, investigando as manifestações culturais brasileiras emergentes e periféricas. Atua como curador, pesquisador, produtor e gestor cultural.

Ficha Catalográfica

Silva, Alexandre dos Santos

Rompendo em fé : as representações evangélicas nas narrativas de artistas contemporâneos brasileiros / Alexandre dos Santos Silva ; orientador: Fred Coelho. $-2021$.

155 f. : il. color. ; $30 \mathrm{~cm}$

Dissertação (mestrado)-Pontifícia Universidade Católica do Rio de Janeiro, Departamento de Letras, 2021.

Inclui bibliografia

1. Letras - Teses. 2. Neopentecostal. 3. Arte contemporânea. 4. Representação. 5. Pentecostalismo. 6. Modernidade. I. Coelho, Frederico Oliveira. II. Pontifícia Universidade Católica do Rio de Janeiro. Departamento de Letras. III. Título.

CDD: 800 


\section{Agradecimentos}

O presente trabalho foi realizado com apoio da Coordenação de Aperfeiçoamento de Pessoal de Nível Superior - Brasil (CAPES) - Código de Financiamento 001

Agradeço ao meu orientador Professor Fred Coelho pelo estímulo, dedicação e parceria que, em tempos tão adversos, foram ainda mais fundamentais para a realização deste trabalho.

Ao CNPq e à PUC-Rio, pelos auxílios concedidos, sem os quais este trabalho não poderia ter sido realizado.

Ao meu amor Juca, que esteve presente em cada etapa dessa difícil jornada acadêmica e pandêmica, me fortalecendo com seu companheirismo fidelíssimo, sua atenção cuidadosa e suas contribuições preciosas a esta pesquisa.

Aos meus enteados Chico e Cecília, pela companhia vital nessa quarentena.

À minha mãe, que acompanha, torce e celebra minhas conquistas desde sempre.

Às minhas amigas Binha e Amarela, por estarem sempre por perto.

Ao meu bonde das bonecas, amigas e amigos, parcerias de vida, que vibram comigo na frequência do amor fraternal.

Às professoras Dinah Oliveira, Helena Martins, Marília Rothier e Raíssa de Góes, pelas escutas, leituras e contribuições ao meu trabalho. E às professoras Aline Leal e Eliska Altmann, que participaram da Comissão examinadora.

À Lívia Reis pelas referências fundamentais para esta investigação.

Aos meus colegas de turma de mestrado da PUC-Rio. Que sorte poder contar com o apoio e companhia de um grupo tão competente, diverso e afetuoso.

Às/os/es artistas que compõem essa pesquisa.

A todos e todas que de alguma forma me estimularam nessa trajetória em busca do conhecimento. Em tempos mórbidos (e negacionistas), a pesquisa, a ciência e a educação se impõem também como afirmação de vida. 


\section{Resumo}

Silva, Alexandre dos Santos; Coelho, Frederico. Rompendo em fé - As representações evangélicas nas narrativas de artistas contemporâneos brasileiros. Rio de Janeiro, 2021. Dissertação de Mestrado - Departamento de Letras, Pontifícia Universidade Católica do Rio de Janeiro.

Desde a década de 1970, o Brasil testemunha o crescimento exponencial das igrejas denominadas neopentecostais, resultando em um consistente e acelerado aumento da sua população evangélica. Estima-se que em aproximadamente uma década os evangélicos serão o maior grupo religioso do país, desbancando a hegemonia católica que vinha sendo mantida por mais de cinco séculos. Esse fenômeno de transição religiosa no Brasil tem tido cada vez mais visibilidade na agenda pública nacional, influência na política e impacto em aspectos socioeconômicos e culturais do país. Contudo, mesmo com todo esse destaque, ainda são raras as elaborações sobre o crescimento pentecostal brasileiro que proponham leituras fora dos âmbitos da sociologia ou da antropologia.

Esta pesquisa busca investigar como narrativas emergentes associadas aos códigos pentecostais aparecem em trabalhos de artistas contemporâneos brasileiros, abordando os diferentes contextos sócio-culturais em que são produzidas - e por onde circulam - as representações artísticas sobre o tema, traçando pontos de contato entre a história do evangelicalismo no Brasil e suas escassas (embora crescentes) inserções no contexto das artes visuais. Para isso, será destacadaa obra performática de Ventura Profana, em interlocução com outros artistas contemporâneos, como Bárbara Wagner, Benjamin de Burca, Coletivo A Noiva, Guerreiro do Divino Amor, Leandro Vieira, Maxwell Alexandre e Virgínia de Medeiros, se atentando especialmente para os contextos curatoriais e institucionais nos quais os trabalhos são apresentados.

Ao abordar os contatos entre símbolos evangélicos e a arte contemporânea brasileira, elabora-se também possíveis relações - de aproximação ou contraste entre a fé e os projetos de modernidade brasileira propostos por esses grupos e movimentos, abarcando discussões sobre o conceito moderno de secularização e o suposto reencantamento do mundo na pós-modernidade. Sendo a arte contemporânea esse segmento irrestrito e permeável, esta dissertação propõediálogos com produções artísticas que extrapolam os limites das artes visuais, trazendo para o campo de discussão referências de diversas áreas do conhecimento e linhas de pensamento. Busco, assim, conduzir um pensamento 
crítico sobre os tópicos referentes a essa pesquisa que evite uma leitura reducionista do candente e complexo tema da presença evangélica no Brasil.

Palavras-chave: neopentecostal; arte contemporânea; representação; pentecostalismo; modernidade 


\section{Abstract}

Silva, Alexandre dos Santos; Coelho, Frederico (Advisor). Breaking in faith Evangelical representations in the narratives of contemporary Brazilian artists. Rio de Janeiro, 2021. Dissertação de Mestrado - Departamento de Letras, Pontifícia Universidade Católica do Rio de Janeiro.

Since the 1970s, Brazil has faced the exponential growth of churches called neo-Pentecostals, resulting in a consistent and accelerated increase in the brazilian evangelical population. It is estimated that in approximately a decade evangelicals will be the largest religious group in Brazil, overriding the Catholic hegemony that had been maintained for more than five centuries. This phenomenon of religious transition in Brazil has been increasingly visible in the public discussion, influence on politics and impact on socioeconomic and cultural aspects of the country. However, even with all this prominence, elaborations on Brazilian Pentecostal growth that propose readings outside the scope of sociology or anthropology are still rare.

This research seeks to investigate how emergent narratives associated with Pentecostal codes appear in the works of contemporary Brazilian artists, addressing the different socio-cultural contexts in which artistic representations on the subject are produced - and where they circulate, tracing points of contact between history of evangelicalism in Brazil and its few (albeit increasing) insertions in the context of the visual arts. For this objective, the artistic work of Ventura Profanawill be highlighted, in dialogue with other contemporary artists, such as Bárbara Wagner and Benjamin de Burca, Coletivo A Noiva, Guerreiro do Divino Amor, Leandro Vieira, Maxwell Alexandre and Virgínia de Medeiros, paying particular attention to the curatorial and institutional contexts in which the works are presented.

When addressing the contacts points between (neo)Pentecostal evangelicalism and contemporary art in Brazil, possible relations - of approximation or contrast - between the Brazilian modernity projects proposed by these groups and movements, encompassing discussions about the modern concept of secularization and the supposed re-enchantment of the world in postmodernity.Considering contemporary art as this unrestricted and permeable segment, the research proposes dialogues with artistic productions that go beyond the limits of visual arts, bringing to the discussion field references from different areas of knowledge. In this way, I seek to conduct a critical thought on the topics related to this research that avoids a reductionist reading of the burning and complex theme of the evangelical presence in Brazil. 
Keywords: neopentecostal; contemporary art; representation; pentecostalism; modernity 


\section{Sumário}

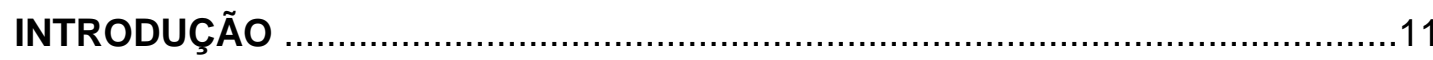

CAPÍTULO 1: Do protestantismo ao neopentecostalismo: a contra-hegemonia e o novo projeto hegemônico.......................................................................... 14

1.1. Brasil Evangélico ................................................................. 14

1.2. O Surgimento pentecostal ..................................................15.

1.3. Uma breve história do pentecostalismo no Brasil .........................18

CAPÍTULO 2: Modernidades e modernismo: arte e religião como expressões de

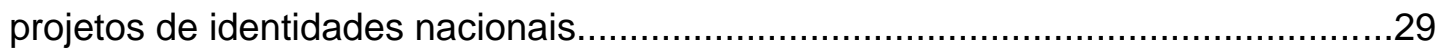

2.1. Protestantismo e modernidade ..................................................29

2.2. Modernidades na arte e religião no Brasil: o pentecostalismo e o modernismo brasileiro ...................................................................... 35

CAPÍTULO 3: O Cristo evangélico na arte contemporânea brasileira ....................44

3.1. Exposição Renovação Carismática ................................................44

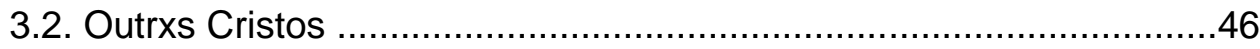

3.3. Um problema de representação: conflitos da comunidade evangélica

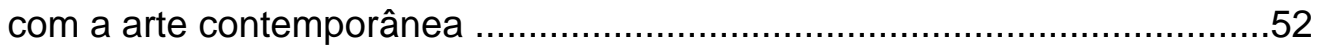

3.4. Ventura Profana: abundante vida.................................................61

3.5. O Reino é das Bichas ......................................................................68

3.6. Superficções Pentecostais .........................................................79

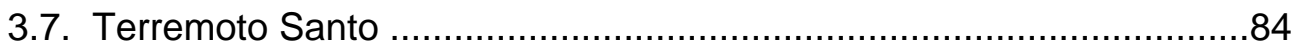

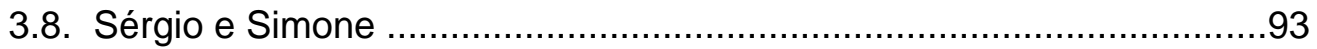

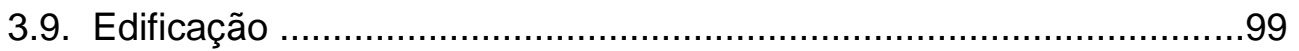

3.10. O Batismo de Maxwell Alexandre .............................................110

3.11. A Igreja do Reino da Arte .....................................................119

3.12. Traquejos Pentecostais para Matar o Senhor ...............................126

3.13. Plantações de Traveco ...........................................................129

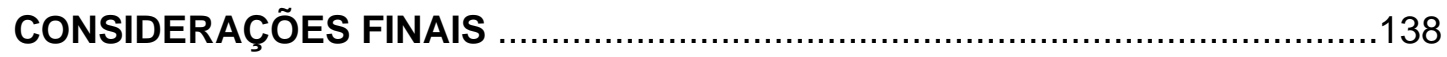


REFERENCIAS BIBLIOGRÁFICAS..................................................... 141

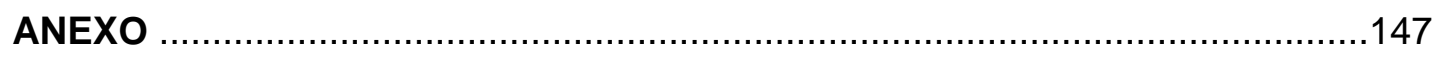




\section{Introdução}

No final da primeira década dos anos 2000 , voltando de mais um dia de aulas de um curso na Escola de Artes Visuais, no Parque Lage, localizado na Zona Sul do Rio de Janeiro, desci do ônibus na praça central do bairro em que morava, em Belford Roxo, na Baixada Fluminense. Nesse dia, durante minha habitual caminhada para casa, comecei a prestar atenção na quantidade de igrejas evangélicas que encontrava pelo caminho. Contabilizei nove congregações, num trajeto de aproximadamente um quilômetro. Perceber que a quantidade de templos que me deparei pelo caminho era quatro vezes maior do que o número de padarias da mesma rua me fez refletir, inopinadamente, sobre o acelerado crescimento da população evangélica no país, especialmente nas regiões periféricas e subúrbios. Além disso, me dei conta de que, ao fazer a viagem cotidiana entre dois polos - em muitos aspectos dessemelhantes - da região metropolitana do Rio, eu estava também diante de uma flagrante disparidade sócio-cultural entre esses territórios: enquanto a paisagem do bairro periférico onde eu morava estava tomada pela iconografia pentecostal, na tradicional escola de artes visuais da Zona Sul da cidade predominava uma lacuna de contato entre a produção artística contemporânea e os símbolos evangélicos. Ocorreu-me, pela primeira vez, pensar que essa falta não seria meramente ocasional.

Qualquer pessoa que tenha vivido no Brasil durante a transição dos anos 1990 para o início do século XXI, especialmente moradores de regiões populares ${ }^{1}$, pôde testemunhar a explosão demográfica cristã-protestante, seja através da proliferação das igrejas chamadas neopentecostais, seja pela crescente presença das manifestações evangélicas em veículos de comunicação em massa, ou até mesmo no expressivo aumento da participação de lideranças pentecostais na política institucional brasileira. Era o momento de eclosão de um projeto de ocupação religiosa em curso há décadas. Segundo o sociólogo brasileiro Ricardo Mariano (2004), a expansão pentecostal no Brasil não é recente nem episódica. Ocorre de modo constante já há meio século, o que permitiu que o pentecostalismo

\footnotetext{
${ }^{1}$ Segundo o Censo 2010, realizado no Brasil, a comparação da distribuição das pessoas de 10 anos ou mais de idade por rendimento mensal domiciliar per capita revelou que os evangélicos pentecostais compõem o grupo religioso com a maior proporção de pessoas na classe de rendimento de até 1 salário mínimo $(63,7 \%)$.
} 
se tornasse o segundo maior grupo religioso do país. Esse crescimento não ficou circunscrito às camadas mais populares da sociedade, embora a adesão às igrejas evangélicas seja mais expressiva dentro da chamada classe C. O pentecostalismo evangélico é o segmento religioso que mais cresce no Brasil, dentre todas as classes sociais.

O Brasil está vivenciando, portanto, a ascensão consistente de uma perspectiva religiosa pentecostalista, que vem se destacando na agenda pública nacional, com desdobramentos nas pautas políticas e impacto em aspectos socioeconômicos e culturais do país. Mesmo com todo esse destaque na sociedade brasileira, ainda são raras as elaborações sobre o crescimento pentecostal brasileiro que proponham leituras fora dos âmbitos da sociologia ou da antropologia. No contexto das artes visuais é possível mapear algumas produções emergentes que refletem de forma heterogênea, tanto nas linguagens quanto nas narrativas, sobre os símbolos evangélicos e sua influência no Brasil contemporâneo. É a partir desse mapeamento preliminar que este estudo se desenvolve.

Frequentei igrejas evangélicas até a adolescência e tenho uma família materna formada majoritariamente por cristãos protestantes, adeptos do segmento neopentecostal. O desenvolvimento desta pesquisa considera, portanto, a perspectiva intrínseca de quem esteve durante parte crucial da vida imerso nesse contexto social, cultural e religioso. Do contraste entre essas minhas vivências - na renomada Escola de Artes Visuais do Parque Lage e no seio de uma família evangélica da periferia fluminense - surgiram as perguntas centrais que direcionam este projeto: onde localizamos as narrativas evangélicas na produção artística contemporânea brasileira? Como são elaboradas essas narrativas? Quem são os sujeitos que abordam essa temática? A que dispositivos recorrem para construir suas representações?

Para tratar sobre representações de emblemas evangélicos na arte contemporânea brasileira, esta pesquisa propõe uma investigação histórica e crítica sobre as interseções dos códigos pentecostais e neopentecostais com as artes visuais no país. Para isso, será destacado o trabalho artístico performático da artista baiana (radicada no Rio de Janeiro) Ventura Profana, em interlocução com outros artistas, como Bárbara Wagner, Benjamin de Burca, Coletivo A Noiva, Guerreiro do Divino Amor, Maxwell Alexandre e Virgínia de Medeiros, atentando-se especialmente para os contextos curatoriais e institucionais nos quais os trabalhos 
são apresentados. Ao abordar os contatos entre os evangelicalismos pentecostais e a arte contemporânea no Brasil, elaboram-se neste estudo possíveis relações (de contrastes e aproximações) dos projetos de modernidade (ou modernização) brasileira propostos/engendrados por esses segmentos. 


\section{CAPÍTULO 1: DO PROTESTANTISMO AO NEOPENTECOSTALISMO: A CONTRA-HEGEMONIA E O NOVO PROJETO HEGEMÔNICO.}

\subsection{Brasil evangélico}

Desde a década de 1970, o Brasil tem testemunhado um significativo crescimento da parcela da população que professa a fé evangélica. Para se ter uma ideia do aumento exponencial dessa adesão, o Censo de $2010^{2}$, realizado pelo IBGE (Instituto Brasileiro de Geografia e Estatísticas), aponta que 42,3 milhões de brasileiros se declararam evangélicos, representando $22,2 \%$ da população brasileira. Em 2000, o mesmo estudo estatístico apresentava o grupo evangélico como $15,4 \%$ dos brasileiros. Esse aumento -mais do que o dobro em relação às duas pesquisas- evidenciava a conquista de 16 milhões de fiéis evangélicos apenas na primeira década do século XXI no Brasil. Em 2019, o Datafolha publicou uma pesquisa $^{3}$ na qual a porcentagem de adeptos às igrejas evangélicas aparece como $31 \%$ da população brasileira. Alguns estudos ${ }^{4}$ apontam que em aproximadamente dez anos a parcela evangélica da população brasileira ultrapassará a de fiéis católicos.

O Brasil ainda é considerado o maior país católico do mundo e possui mais de 100 milhões de habitantes que se auto declaram católicos apostólicos romanos (praticantes ou não praticantes). A Igreja Católica está presente no país desde o início do projeto colonial português, há mais de cinco séculos. A primeira missa foi realizada no dia 26 de abril de 1500, quatro dias após o primeiro desembarque da frota de Pedro Álvares Cabral (um católico fervoroso). A Igreja participou ativa e estrategicamente do projeto de colonização e cresceu se fortalecendo junto às populações rurais, com baixa mobilidade social e com pouco dinamismo, através da catequização. Em termos percentuais, os católicos representavam mais de $90 \%$ da população em meados do século XX. Este quadro, porém, vem mudando rapidamente nas últimas décadas, configurando o que alguns pesquisadores têm chamado de transição religiosa brasileira. Indubitavelmente, a premente e inédita

\footnotetext{
${ }^{2}$ http://www.ibge.gov.br/home/estatistica/populacao/censo2010/populacao/religiao_Censo2010.pdf.

${ }^{3}$ https://www1.folha.uol.com.br/opiniao/2020/01/onda-evangelica.shtml

${ }^{4}$ http://www.revistas.usp.br/ts/article/view/112180
} 
mudança hegemônica entre os dois grandes grupos religiosos do Brasil está em curso, e os impactos dessa transição influenciam diversos setores da sociedade.

O crescimento da parcela evangélica da população brasileira incide, consequentemente, no aumento da participação de líderes pentecostais na política partidária. Não é exatamente novidade a institucionalização política de evangélicos no Brasil. Porém, as eleições de 2018 deflagraram um panorama bem delineado sobre a força de grupos conservadores que se associam às religiões pentecostais com objetivos eleitorais. Enquanto em 1982 o número de parlamentares declaradamente evangélicos era de 12, em 2018 esse número cresceu para 89 deputados, segundo o Departamento Intersindical de Assessoria Parlamentar $(\mathrm{DIAP})^{5}$. O atual presidente da república, Jair Messias Bolsonaro, mesmo sendo declaradamente católico, foi eleito em 2018 com expressivo apoio dos setores mais fundamentalistas e conservadores das igrejas evangélicas brasileiras. Um apoio contundente que lhe confere status de, mais do que uma liderança política, um desígnio divino ao seu governo. "Brasil acima de tudo. Deus acima de todos", diz o slogan do Governo Federal sob seu comando.

Embora o foco deste estudo seja a relação dos símbolos evangélicos com as artes visuais no Brasil, considero imprescindível que sejamos contextualizados introdutoriamente com algumas abordagens históricas sobre o protestantismo e, especialmente, acerca do surgimento do movimento pentecostal e seus desdobramentos. Para isso, abarcaremos leituras no âmbito da sociologia da religião que teorizam o crescimento evangélico no país. Adiante, pretende-se correlacionar os marcos importantes da ascensão pentecostal no Brasil com eventos da história recente da arte brasileira, destacando os - incipientes - pontos de contato entre os dois movimentos.

\subsection{O surgimento pentecostal}

O movimento pentecostal é considerado por muitos estudiosos o fenômeno mais expressivo da história moderna do cristianismo. E talvez seja um dos mais marcantes de toda a história da igreja cristã. Em relativamente poucas décadas, as igrejas evangélicas pentecostais reuniram uma imensa quantidade de pessoas em

\footnotetext{
${ }^{5}$ https://www.diap.org.br/index.php/noticias/agencia-diap/89610-a-forca-da-bancada-evangelica-naseleicoes-municipais
} 
praticamente todos os continentes, totalizando hoje, segundo cálculos estimativos, mais de meio bilhão de adeptos em todo mundo. Mais do que um dado quantitativo, o pentecostalismo acarretou mudanças profundas na cultura cristã de maneira geral, rompendo com uma série de padrões que caracterizavam as igrejas protestantes (que, por sua vez, já se apresentavam como rompimento aos paradigmas católicos tradicionais) há alguns séculos e propondo reinterpretações muitas vezes bastante radicais da teologia, das liturgias e da própria experiência religiosa.

O protestantismo, marco histórico inicial de todas as igrejas evangélicas, resultado da Reforma Protestante originada na Inglaterra, no século XVI, é um movimento cristão que, ao contrário do catolicismo, reporta a autoridade divina principalmente à Bíblia, se opondo à infalibilidade do papa (e, portanto, sua doutrina religiosa é evangélica, em vez de apostólica, como o catolicismo). Nessa perspectiva, ser evangélico não constitui um sujeito religioso no sentido ritualístico ou burocrático, mas sim em um encontro pessoal com Jesus, o Espírito Santo e Deus, o Pai. Essa perspectiva é imprescindível para entendermos a crescente adesão evangélica também como manifestação de um desejo de expressão religiosa que considere a individualidade dos sujeitos.

Resumidamente, o pentecostalismo distingue-se do protestantismo histórico, do qual é herdeiro direto, por pregar a crença na contemporaneidade dos dons do Espírito Santo. Entre os dons espirituais pentecostais destacam-se a glossalia, que é a capacidade do fiel se expressar através de línguas que o próprio não é fluente, (popularmente chamada de "língua dos anjos"); discernimento de espíritos; e por defender a retomada de credos e práticas oriundas do cristianismo primitivo, como a cura de enfermos, a expulsão de demônios, a concessão divina de bênçãos e a realização de milagres.

O termo "pentecostes" vem do grego pentēkostế, que significa "quinquagésimo". A origem dessa festa é baseada em uma antiga tradição hebraica, chamada Shavuoth, que significa "Semanas". Era uma celebração de agradecimento a Deus pela colheita realizada pelos judeus cinquenta dias após a Páscoa. A data também homenageia a memória do dia em que Moisés recebeu as Tábuas com as Leis Sagradas, conhecidas por Torah. Essa festa reunia em Jerusalém multidões de hebreus vindos de vários países. Para os cristãos, a comemoração do Pentecostes é marcada pela narrativa no livro dos "Atos dos 
Apóstolos", capítulo 2, momento em que os apóstolos de Cristo recebem o Espírito Santo:

1. Quando chegou o dia de Pentecostes, todos os seguidores de Jesus estavam reunidos no mesmo lugar. 2. De repente, veio do céu um barulho que parecia o de um vento soprando muito forte e esse barulho encheu toda a casa onde estavam sentados. 3. Então todos viram umas coisas parecidas com chamas, que se espalharam como línguas de fogo; e cada pessoa foi tocada por uma dessas línguas. 4. Todos ficaram cheios do Espírito Santo e começaram a falar em outras línguas, de acordo com o poder que o Espírito dava a cada pessoa.

A história da lgreja é marcada por alguns momentos dos chamados "avivamentos", que são, na prática, a revitalização e o aprofundamento da experiência religiosa na vida de indivíduos e grupos, geralmente de modo catártico, através de episódios de manifestações espirituais, de conversões em massa e "ocorrências milagrosas" coletivas. O Antigo e o Novo Testamentos mencionam vários eventos dessa natureza, e isso tem se repetido inúmeras vezes na história do cristianismo. O protestantismo tem sido um campo fértil para tais episódios, inicialmente na Europa e depois nos Estados Unidos. O mais marcante avivamento da história recente da igreja protestante marcou o surgimento do movimento pentecostal.

Tradicionalmente, reconhece-se o começo do pentecostalismo com o fato ocorrido em 1906, em Los Angeles (EUA), na Rua Azusa, liderado por William Joseph Seymour, um pregador afro-americano. O Avivamento da Rua Azusa, como ficou historicamente conhecido, teve início com uma reunião em 14 de Abril de 1906, em um prédio que fora da Igreja Metodista Episcopal Africana, e continuou até meados de 1915. O episódio foi caracterizado por experiências de glossolalia, cultos de adoração e o caráter interracial do movimento. Os participantes foram criticados pela mídia secular e teólogos cristãos conservadores por considerarem o comportamento escandaloso e pouco ortodoxo, especialmente para a época. Hoje, o avivamento é considerado pelos historiadores como principal catalisador para a propagação do pentecostalismo no século XX. 


\subsection{Uma breve história do pentecostalismo no Brasil}

O que comumente chamamos de "evangelicalismo" é um rótulo genérico para designar o resultado de um processo histórico abrangente, no qual emergiram diferentes grupos herdados do cisma religioso do século XVI: luteranos, metodistas, calvinistas, batistas, menonitas, presbiterianos e pentecostais, entre as denominações mais conhecidas. Veremos no decorrer deste estudo que a profusão de termos elaborados para tratar do segmento evangélico no Brasil promovem, em certo sentido, uma dificuldade de associações imediatas do objeto de pesquisa com seus predicados. Considerando que grande parte dessas expressões são importadas de outros contextos sócio-culturais que não o brasileiro, a catalogação das nomenclaturas serve a um enquadramento muitas vezes impertinente a um fenômeno tão dinâmico, diverso e em progresso, É importante ressaltar, portanto, que tais confusões derivam - e deflagram - justamente da necessidade de ampliação do repertório de estudos e abordagens atualizadas sobre o tema.

Faremos então exercícios de tentar elucidar algumas diferenças e destacar nuances sobre conceitos que abarcam o universo das manifestações evangélicas emergentes no país sem o compromisso de cristalização dessas definições. Busco, dessa forma, compor um panorama que considere a complexidade do tema. Segundo Cavalcanti:

A palavra "evangélicos" aparece em três sentidos: no sentido amplo, europeu, é apenas sinônimo de protestante; no sentido amplíssimo, latino-americano, é sinônimo de todo cristão não-católico romano (o IBGE inclui, até, mórmons e testemunhas de Jeová); outro, restrito, específico, no sentido inglês, representa uma vertente da Igreja com ênfase no relacionamento pessoal com Cristo, em reação a uma religião estatal e sacramentalista. Embora o termo "evangélico" seja encontrado na Patrística e na Reforma, ele adquire um conceito mais claro e se torna um movimento na Inglaterra, na segunda metade do século XVIII e primeira metade do século XIX, culminando com a organização da primeira Aliança Evangélica em 1847. Resgatando uma herança que vem de Wycliffe, no século XIV, chegando até os Avivamentos, passando pela confessionalidade reformada, o puritanismo e o pietismo, deságua no movimento missionário do século $\mathrm{XIX}$, do qual foi a sua proposta principal. A escatologia do movimento missionário ou era posmilenista ou amilenista, com clara opção por uma 
participação social e uma influência histórica. (CAVALCANTI, 2013, p. 7-8)

O IBGE classifica o grupo de evangélicos no Brasil sob duas nomenclaturas principais: 1) Evangélicos de missão e 2) Evangélicos pentecostais. Destes dois grupos, o aumento de fiéis tem sido mais significativo entre os evangélicos pentecostais, de acordo com as pesquisas realizadas em 2000 e 2010. Os resultados do Censo Demográfico 2010 mostram que a proporção de católicos seguiu a tendência de redução. Em paralelo, consolidou-se o crescimento da população evangélica, que passou de 15,4\% em 2000 para 22,2\% em 2010. Dos que se declararam evangélicos, $60,0 \%$ eram de origem pentecostal, 18,5\%, evangélicos de missão e 21,8 \%, evangélicos não determinados.

As primeiras manifestações pentecostais no Brasil datam do início do século XX. O primeiro missionário pentecostal chegou ao país em 1910, quando o italiano Luigi Francescon fundou a Congregação Cristã no Brasil, na cidade de São Paulo. Apenas um ano depois, em 1911, os missionários suecos Gunnar Vigren e Daniel Berg fundaram a Assembleia de Deus, em Belém, Pará. Embora europeus, os três missionários converteram-se ao pentecostalismo nos Estados Unidos, de onde partiram para evangelizar o Brasil. O movimento pentecostal no Brasil está, portanto, intimamente ligado ao pentecostalismo norte-americano.

Essas duas igrejas precursoras dominaram o campo pentecostal brasileiro nos primeiros 40 anos após suas fundações. A Congregação Cristã concentrou sua atuação na circunscrição das comunidades de imigrantes italianos. Ao se isolar do contato com outras igrejas pentecostais, manteve-se assim mais apegada a certos traços sectários e tradicionalistas. Já a Assembleia de Deus mostrou, sobretudo nas décadas mais recentes, maior disposição para adaptar-se a mudanças em processo no pentecostalismo e na sociedade brasileira, configurando-se como uma das denominações evangélicas mais populares do país.

De início, na condição de grupos religiosos minoritários em terreno "hostil", ambas as igrejas caracterizaram-se pelo anticatolicismo, por radical sectarismo e ascetismo de rejeição do mundo. No plano teológico, enfatizaram o dom de línguas, seguindo a ênfase doutrinária primitiva dessa religião. (MARIANO, 2004, p.123) 
De acordo com alguns sociólogos, como Paul Freston (1995) e o já mencionado Ricardo Mariano (2004), a história do pentecostalismo no Brasil pode ser dividida em três momentos históricos, conhecidos como "as três ondas pentecostais". A implementação das igrejas Assembleia de Deus e Congregação Cristã no Brasil marca a primeira onda, também chamada de pentecostalismo clássico. Essa classificação temporal e episódica das três ondas é feita com base em marcos históricos (ou periodização) de surgimentos denominacionais e em distinções teológicas e comportamentais.

A segunda onda ocorreu entre o final da década de 1950 e início dos anos 1960, quando houve uma significativa fragmentação do campo pentecostal e surgiram, entre muitos outros, três grandes grupos ainda ligados ao pentecostalismo clássico: Igreja do Evangelho Quadrangular (1951), Igreja Evangélica Pentecostal O Brasil para Cristo (1955) e Igreja Pentecostal Deus é Amor (1962); todas voltadas de modo especial para a cura divina. Nesse momento, o pentecostalismo no Brasil já era considerado o terceiro maior do mundo.

Essa segunda onda está contextualizada historicamente com o aumento do processo de urbanização do país e o crescimento acelerado das grandes cidades. Freston argumenta que o estopim dessa nova fase foi a chegada da Igreja do Evangelho Quadrangular com os seus métodos arrojados, forjados no berço dos modernos meios de comunicação de massa na Califórnia. Esse período revela uma tendência relevante - a crescente nacionalização do segmento pentecostal brasileiro. Embora a Igreja Quadrangular ainda tenha sua origem estadunidense, as outras duas surgidas na mesma época tiveram raízes integralmente brasileiras. Paul Freston (1993) defende que essas mudanças ocorreram por uma "questão de estilo cultural" (Freston, 1993:82): para ele, os novos grupos podiam se adaptar melhor à sociedade urbana, pois não carregavam nas costas quarenta anos de tradição, como a Assembleia de Deus. Dessa forma, como indica Mariano, eram mais livres para usar técnicas modernas e criar uma nova relação com a sociedade.

Os missionários da Quadrangular conferiram ênfase teológica à cura divina, seguindo o bem-sucedido movimento de cura propagado nos Estados Unidos durante a Segunda Guerra Mundial. Como estratégia proselitista, além da ênfase na cura, essa vertente pentecostal notabilizou-se pelo intenso uso do rádio e pela pregação 
itinerante com o emprego de tendas de lona. (MARIANO, 2004)

A estratégia Quadrangular no investimento missionário através dos meios de comunicação em massa e pontos de evangelização itinerantes, pavimentou 0 caminho para que a terceira onda do pentecostalismo no Brasil fosse marcada fortemente pelas estratégias de massificação dos aparatos de evangelização.

Neste ponto é importante articular que algumas condições e contextos que favoreceram o surgimento de novas denominações pentecostais: a influência cultural norte-americana, o crescimento dos centros urbanos no Brasil, o avanço industrial e a dos veículos de comunicação em massa. Essas transformações também foram suportes para um projeto de modernidade desenvolvido no segmento artístico através, especialmente, do modernismo brasileiro. Logo adiante trataremos melhor desse tópico.

A terceira onda histórica do pentecostalismo brasileiro começou no final dos anos 1970 e ganhou força a partir da década seguinte, com o surgimento das igrejas denominadas neopentecostais, caracterizadas pela ênfase na Teologia da Prosperidade. O neopentecostalismo no Brasil tem sido marcado pela heterogeneidade do segmento e de suas manifestações. Embora tenha a Igreja Universal do Reino de Deus (1977) como expoente mais notável, o movimento neopentecostal tem outros grupos influentes como a Igreja Internacional da Graça de Deus (1980), Igreja Renascer em Cristo (1986), Comunidade Sara Nossa Terra (1992), Igreja Paz e Vida (1982), Comunidades Evangélicas, e muitas outras. O IBGE $^{6}$ calcula que são abertas anualmente 14 mil igrejas evangélicas no país.

O fenômeno neopentecostal, principal motor do crescimento evangélico no Brasil, tem como expressão religiosa básica o trinômio cura-exorcismoprosperidade, praticados em diferentes proporções de acordo com as denominações. Diante dos aspectos de desigualdade social, pluralidade e alienação que tanto caracterizam as sociedades modernas, principalmente no contexto das grandes cidades, as igrejas neopentecostais oferecem espaços de solidariedade e acolhimento, gerando um forte senso de dignidade e pertencimento comunitário entre os seus participantes. Na prática, as congregações constituem uma base de assistência não apenas espiritual, mas também social aos seus fiéis. Em um

\footnotetext{
${ }^{6}$ https://revistapesquisa.fapesp.br/wp-content/uploads/2019/11/012-019_Evangelicos_286.pdf
} 
contexto político neoliberal, marcado pelo enfraquecimento do papel do Estado na resolução de questões de ordem sócio-econômica, o empreendedorismo autônomo das igrejas neopentecostais se consolida como aparatos culturais e espaços de sociabilidade onde, muitas vezes, o aspecto religioso fica em segundo plano.

Por outro lado, paradoxalmente, algumas dessas igrejas revelam uma forte tendência para práticas sincréticas e mágicas, tais como a utilização crescente de objetos e rituais como mediação do sagrado, a adoção do vocabulário e práticas da religiosidade popular brasileira, deixando o uso da Bíblia principalmente como um instrumento para a solução de problemas. Essas características evidenciam o percurso de distanciamento que o movimento pentecostal - especialmente considerando as igrejas neopentecostais - tem feito em relação ao pentecostalismo clássico e suas bases teológicas e litúrgicas. Segundo Ricardo Mariano:

\begin{abstract}
Sem perder necessariamente sua distintividade religiosa, as igrejas neopentecostais revelam-se, entre as pentecostais, as mais inclinadas a acomodarem-se à sociedade abrangente e a seus valores, interesses e práticas. Daí seus cultos basearem-se na oferta especializada de serviços mágico-religiosos, de cunho terapêutico e taumatúrgico, centrados em promessas de concessão divina de prosperidade material, cura física e emocional e de resolução de problemas familiares, afetivos, amorosos e de sociabilidade. (MARIANO, 2014)
\end{abstract}

A Teologia da Prosperidade, base teológica do segmento neopentecostal, se ancora na ideia de que a medida da fé do fiel pode ser aferida através de seu sucesso financeiro e saúde plena: física, emocional e espiritual. Para isso, o crente precisa, necessariamente, se comprometer a apoiar financeiramente a congregação através de suas ofertas e do dízimo. A Teologia da Prosperidade diz respeito, portanto, à maneira de compreender a ação de Deus em resposta às ações humanas. É um discurso religioso que rejeita a teodiceia cristã tradicional, fundando uma lógica moderna de relação humana com o sagrado, concatenando aspectos místicos e sectários, na qual fé e prosperidade não podem mais estar dissociadas.

Ao articular prosperidade financeira com bem estar emocional e espiritual, a lógica protestante favorece a propagação do "espírito capitalista", como desenvolveu o sociólogo alemão Max Weber, em seu célebre estudo A ética 
protestante e o espírito do capitalismo (1905-1905). Uma das ideias contidas na obra de Weber que produzem mais ressonâncias ainda nos tempos atuais é o paradigma da "secularização", que trataremos nos próximos capítulos. Segundo a antropóloga Paula Montero (2009):

Como se sabe, esse paradigma supõe que, no processo histórico de construção da modernidade, o Estado se tornaria cada vez menos acessível aos processos de moralização e a religião, desprovida de suas funções integradoras do passado, se deslocaria para o mundo privado, assentando sua plausibilidade não mais no poder político, mas nas consciências individuais. (MONTERO, 2009, p. 8)

Considerando a expressiva adesão dos brasileiros ao segmento religioso neopentecostal nas últimas décadas, associada ao declínio constante dos adeptos do catolicismo, é inevitável pensarmos que o discurso da "opção preferencial pelos pobres" da Igreja Católica tem perdido o lugar para a lógica da prosperidade financeira sem culpa, pregada pelas igrejas evangélicas. Nesse sentido, a Teologia da Prosperidade tem favorecido às aspirações de mobilidade sócio-econômica, cujas consequências dessa adesão em massa têm sido objeto de estudos sobre as recentes reconfigurações das camadas sociais no Brasil. O demógrafo José Eustáquio Diniz Alves (2012) recorre à célebre frase atribuída ${ }^{7}$ ao carnavalesco Joãosinho Trinta ("Pobre gosta de luxo!") para destacar a diferença da relação dos evangélicos neopentecostais e dos católicos com a prosperidade individual financeira através do acúmulo de capital. Eustáquio (2012) complementa: "a lógica econômica tem prevalecido sobre a dinâmica puramente religiosa. A teologia da prosperidade tem atendido melhor às expectativas de consumo e os interesses ambiciosos das diferentes camadas sociais".

\footnotetext{
${ }^{7}$ Há controvérsias sobre a autoria da frase "quem gosta de miséria é intelectual; pobre gosta de luxo". Em uma entrevista ao jornalista Luiz Fernando Vianna, para o Jornal Folha de São Paulo, em 2006, Joãosinho respondeu: "Há uns dois anos, o Elio Gaspari [colunista da Folha a quem já se atribuiu a frase] escreveu: 'e, como dizia, Joãosinho Trinta, quem gosta de miséria é intelectual; pobre gosta de luxo'. O próprio Gaspari escreveu isso. Quando essa frase surgiu, estávamos em plena ditadura. A esquerda era contra, eu também era contra a ditadura, e eles [da esquerda] diziam que eu não retratava a realidade brasileira. Nunca acreditei na pobreza do Brasil. Sempre confiei no grande potencial do Brasil. E eu fiz o enredo 'Ratos e urubus, larguem minha fantasia' [em 1989] para responder a esse grupo que me acusava. Tudo o que eu pensava e fazia me levava à verdade dessa frase. Eu disse essa frase em ação e pensamento. Agora, se disse exatamente como saiu, não sei. E ela está atualíssima. Quando me referi ao luxo, não falava sobre as riquezas superficiais, mas do luxo da criatividade, da emoção".
} 
Nas sociedades modernas, marcadas pela constituição do sujeito através do consumo, a própria espiritualidade ganha um viés mercadológico. Se é verdade que a reativação pós-moderna do religioso exprime certo desencanto com 0 materialismo da vida cotidiana, o certo é que o fenômeno é cada vez menos exterior à lógica mercantil. A espiritualidade se tornou mercado, produto a ser comercializado, setor a ser gerido e promovido (LIPOVETSKY, 2007, p. 132).

É impossível, portanto, falarmos do crescimento pentecostal no Brasil sem considerarmos os temas de mobilidade sócio-econômica, inclusão social e acesso a bens, serviços e direitos. Segundo a antropóloga Paula Montero:

No caso dos neopentecostais, através das formulações da "teologia da prosperidade", a noção de acesso aos bens articulou-se, paradoxalmente, não à lógica do mercado, mas à do dom e contra-dom, tão bem estudada pela antropologia. Com efeito, nas práticas discursivas neopentecostais, todo indivíduo deve exercer seu "direito à prosperidade", formulação esta que enuncia de modo bastante particular a ideia de "inclusão social" e de "ordem legal" posto que não passa, como no caso do discurso católico, pela noção de fraternidade ou de comunidade. (MONTERO, 2009, p.10)

Seria também inconsistente tratarmos do tema do neopentecostalismo no Brasil sem considerarmos sua localização convenientemente intermediária entre os aspectos da tradição e os anseios de modernidade. No ponto de vista da natureza da manifestação religiosa e do repertório de símbolos elaborados por esse novo segmento, se sublinha a incorporação anacrônica de diversos elementos da cultura popular brasileira. Esse contato não se dá, porém, sem tensão. Em relação ao contato da liturgia (neo)pentecostal com aspectos do catolicismo tradicional - e até mesmo de religiões de matriz africana -, essa operação pode se dar de forma dialética e/ou dialógica, manifestada através de atos discriminatórios e/ou sincretismos. O antropólogo Vagner Gonçalves da Silva aborda o aspecto híbrido das manifestações neopentecostais:

A novidade que vem transformando este cenário (...) é o desenvolvimento do neopentecostalismo que ao se distanciar do pentecostalismo clássico e ao se aproximar da umbanda e de outras religiões afro-brasileiras, ainda que 
seja para negá-las, passou a traduzir para seu próprio sistema o ethos da manipulação mágica e pessoal, mas agora sob nova direção, colocando o "direito" no lugar do "favor". A base sociológica comum entre pentecostais e umbandistas, que propiciava a "dupla resposta à aflição" opostas e distintas - conforme apontada por Fry e Howe, muito provavelmente tenha possibilitado o surgimento desta "terceira resposta à aflição", que se apropria a seu modo das duas anteriores. Ou seja, o neopentecostalismo, ao "abrandar" o ascetismo, suavizando o estereótipo do "crente" do protestantismo histórico, passou a valorizar os prazeres terrenos e a estimular o consumo de bens materiais como sinais da salvação. (SILVA, 2007, p. 206)

Chegamos, nesse ponto da pesquisa, à conexão com o tópico abordado nos primeiros parágrafos deste texto, no qual destaco a presença pentecostal no Brasil como sintoma de uma demanda moderna para novas experiências com o sagrado. No contexto brasileiro, esse fenômeno vai se desenvolver a partir da permeabilidade, através de hibridismos, paradoxos, pluralismos e contradições, próprios da modernidade.

$\mathrm{Na}$ minha caminhada pelo bairro da Baixada Fluminense onde morava, na periferia da região metropolitana do Rio de Janeiro, a paisagem cheia de igrejas neopentecostais refletia uma realidade parecida com outras cidades Brasil afora. Essa realidade tão - literalmente - familiar, me instiga a pensar em um Brasil evangélico que cresceu pelas bordas das cidades, e hoje já ocupa um lugar de centralidade em vários aspectos da vida social brasileira.

O Brasil pentecostal se ergue desenhando uma nova hegemonia religiosa no país. Seus novos paradigmas se desenvolvem, porém, num contexto de pluralismo e heterogeneidade, em um cenário onde outrora predominava a coesão eclesiástica católica sob um programa colonizador. Hoje, vivemos em um país cada vez mais imbricado em seus misticismos. Os novos convertidos ao (neo)pentecostalismo trazem para dentro das suas congregações traços marcantes das expressões religiosas tradicionais do Brasil. O Brasil evangélico é negro. É, também, feminino ${ }^{8}$. Ao mesmo tempo, as religiões de matriz africana passam por um sistemático processo de embranquecimento. Não considero irrelevante o fato de que, além dessas supostas contradições, no país que adere em massa aos aspectos mágicos

\footnotetext{
${ }^{8}$ https://www1.folha.uol.com.br/poder/2020/01/cara-tipica-do-evangelico-brasileiro-e-feminina-e-negraaponta-datafolha.shtml
} 
das manifestações neopentecostais, também cresça o número de pessoas que se dizem sem religião ${ }^{9}$.

Estas contradições que configuram o desenvolvimento do pentecostalismo no Brasil me lembram a figura de minha vó materna, Dona Mocinha, que até a sua morte, aos 86 anos, congregou em uma pequena igreja tradicional evangélica, $O$ Brasil para Cristo, localizada quase em frente à casa onde morava, em Belford Roxo. Migrante de uma região rural do estado do Rio, o município de Miguel Pereira, minha vó, viúva antes dos 40 anos, trocou seu território natal para uma cidade em expansão urbana, em busca de mais oportunidades. Com ela vieram todos os seus onze filhos. Essa migração não foi marcada apenas pela troca de residência, mas também pela adesão a uma nova religião, que atendia melhor às expectativas da nova realidade.

Vovó Mocinha era uma crente convertida e nada ortodoxa. Embora assídua nos cultos dominicais, não deixava de fazer sua "fézinha" no jogo do bicho toda vez que sonhava com algum animal da cartela. Tinha um repertório de palavrões que certamente escandalizaria seu pastor pentecostal (por isso tratava de usá-los somente com seus familiares). Nunca abandonou de vez as várias superstições interioranas. Cresci, portanto, tendo contato de perto com essa forma sincrética de se relacionar com o pentecostalismo. Ou melhor, me habituei ao contato com os símbolos pentecostais a partir dos sincretismos. Embora minha avó nunca tenha manifestado uma característica evangelizadora rigorosa, quase todas as minhas tias, incluindo minha mãe, começaram a frequentar igrejas evangélicas ainda na década de 1990.

Nesse aspecto, também considero muito emblemática a transição religiosa da minha família, consonante com o movimento que a maior parte dos brasileiros fez nesse mesmo período. Tendo batizado todos os filhos nos preceitos católicos, minha vó testemunhou a conversão de nove dos onze filhos à igreja evangélica. Inclusive a de uma tia adepta da Umbanda. Hoje tenho na família quatro pastores, uma delas é minha tia iniciada em terreiros umbandistas. Apenas uma outra tia e um tio seguem resistentes à conversão evangélica e ainda professam sua fé católica, mesmo que incorporando certos hibridismos pentecostais.

Nesse contexto de influência familiar, era quase inevitável que eu frequentasse igrejas evangélicas na minha infância e parte da adolescência.

\footnotetext{
${ }^{9}$ https://www.estadao.com.br/noticias/geral,cresce-numero-de-pessoas-sem-religiao-e-espiritas,893417
} 
Congreguei-me (se é que é possível dizer que uma criança se congrega), sendo levado por tias e minha mãe, em diferentes denominações de igrejas pentecostais e neopentecostais. Tenho memórias remotas sobre as famigeradas "sessões de descarrego" na Igreja Universal e uma vaga lembrança de ver Benedita da Silva pedir votos a fiéis da Assembleia de Deus em Jardim Ulisses, em Nova Iguaçu. Fui a alguns dos grandes ajuntamentos de evangélicos, tão marcantes na primeira década dos anos 2000, como os shows gospel organizado pela Rádio Melodia FM na Quinta da Boa Vista, ou na Apoteose do Rio de Janeiro.

Uma certa ideia de predestinação me encaminhou ao batismo em uma Igreja do Evangelho Quadrangular, aos quinze anos. Essa é a igreja que a maior parte dos evangélicos da minha família ainda frequenta, na qual uma tia e um primo assumiram postos de pastores. Foi nessa igreja que permaneci por mais tempo associado como membro, dentre todas que frequentei. Participei de quadros oficiais da congregação, como o grupo jovem e o ministério de teatro. Bastou menos de um ano após meu batismo para que eu entendesse que aquela escolha não tinha sido tão voluntária assim. Meus interesses intelectuais, artísticos e culturais de um adolescente curioso e argumentador - e, sobretudo, um desejo não maturado de viver minha homossexualidade de forma plena - não cabiam mais no contexto restritivo e pragmático da narrativa evangélica na qual eu estava inserido.

Fiz parte da primeira geração da minha família que conseguiu entrar na universidade. Meu ingresso se deu através das políticas afirmativas de inclusão, implementadas pelo governo de Luís Inácio Lula da Silva, pelo Programa Universidade para Todos (ProUni). Havia naquele momento um sentimento de mobilidade e possibilidades. Quase todos meus colegas de classe do Ensino Médio, alunos de uma escola pública de referência em Nova Iguaçu, na Baixada Fluminense, conseguiram vagas ou bolsas em universidades públicas e privadas. Essa pesquisa também considera a consonância destes movimentos. Embora o surgimento das igrejas neopentecostais seja datado na década de 1970, foi a partir dos anos 2000 que a noção de mobilidade social no Brasil atravessou não apenas aspectos religiosos ou econômicos, mas se apresentou como realidade para muitos moradores de espaços periféricos, como eu. Estamos falando de uma significativa transformação no país, complexa e cheia de camadas, que também incide sobre aspectos culturais e manifestações artísticas que emergiram no Brasil no século XXI. 
Parte dos artistas e obras que aparecem nesta pesquisa está contextualizada na parcela da população que aderiu aos projetos de mobilidade social do país na primeira década dos anos 2000 , seja através da universidade, seja através das igrejas evangélicas, ou mesmo a partir de suas pesquisas artísticas. Longe de ser um panorama completo que pretenda concluir uma visão geral da arte contemporânea brasileira a respeito dos símbolos evangélicos, busco destacar nessa investigação a intencionalidades das narrativas de artistas visuais através de seus próprios discursos sobre os trabalhos. Nesse sentido, pretende-se localizar o leitor sobre o percurso de cada pesquisa artística abordada, ressaltando quais são os contatos estabelecidos entre os tópicos pentecostais e a produção das obras. 


\section{CAPÍTULO 2: MODERNIDADES E MODERNISMO: ARTE E RELIGIÃO COMO EXPRESSÕES DE PROJETOS DE IDENTIDADES NACIONAIS}

\subsection{Protestantismo e modernidade}

Em uma perspectiva meramente cronológica e historiográfica, convencionouse chamar de Idade Moderna o período que começa com a tomada de Constantinopla (1453) ou, em outras perspectivas, com a suposta "descoberta" do Novo Mundo (1492), e se estende até a Revolução Francesa (1789), quando se inicia a Idade Contemporânea. Porém, sabemos que o conceito de modernidade não está circunscrito aos marcos históricos que instauraram a Era Moderna. Ademais, as marcações de tempo e as nomenclaturas acerca do que é a modernidade têm sido colocadas sistematicamente em questão por diversas áreas de conhecimento e linhas de pensamento. Do ponto de vista da filosofia, a modernidade teria sido iniciada na Idade Média Tardia, ou mais precisamente no Renascimento, com os pensamentos filosóficos e políticos de René Descartes e Thomas Hobbes, na segunda metade do século XVII. É muito frequente, entre os historiadores da filosofia, considerar o começo da modernidade a partir do século XVII, com Descartes, e o seu término no final do século XVIII, com Immanuel Kant. É esta a leitura que predominou, sobretudo, a partir de Hegel. Convém, no entanto, lembrar que muitos pensadores - tais como Alain Badiou, Christian Jambet e Guy Lardreau - consideram a modernidade como um processo que ainda não se fechou definitivamente.

Há, portanto, distinções importantes a serem consideradas, dada a constância da confusão sobre o domínio de conceitos ligados à modernidade. Embora a modernidade, como delineação de uma Era tenha início no período renascentista, o adjetivo "moderno" - do latim tardio: modernus - remonta sua origem ao século VI. Porém, foi apenas a partir do começo do século XX que se desenvolveram e se intensificaram os debates em torno do conceito de modernidade e, consequentemente, daqueles dois movimentos que the estão intimamente vinculados: a Reforma Protestante e o fenômeno da secularização.

A modernidade, em termos gerais, é marcada como a superação do pensamento e das organizações sociais tradicionais que caracterizam o período medieval. A ruptura com o pensamento escolástico, método crítico associado aos preceitos da Igreja Católica, e o estabelecimento da racionalidade como forma 
autônoma de desenvolvimento do conhecimento, desvinculado de princípios teológicos, foram alguns dos primeiros passos em direção à construção do pensamento moderno. Abriu-se então caminho para a elaboração de uma epistemologia predominantemente secular, desdobrada na universalização dos direitos sociais e das liberdades individuais, que resultou, por exemplo, na Declaração dos Direitos do Homem e do Cidadão. No bojo desse movimento, veio também a consolidação de um sistema republicano laico, pautado pela representatividade popular, hoje chamado de democracia representativa.

A secularização, ou seja, esse processo através do qual a religião perde a sua influência sobre as variadas esferas da vida social, separando os âmbitos culturais que estão ligados à crença das demais esferas da vida social - como a política, os aspectos monetários e os processos legais no âmbito do Direito - é um dos pilares do pensamento moderno. Muitos cientistas sociais consideram a secularização como o marco inicial dos estudos da sociologia da religião. Max Weber, sociólogo alemão já citado neste estudo, é um pensador fundamental na articulação do conceito de secularização com a modernidade. Para Weber, a secularização está ligada à ideia de "desencantamento do mundo", um legado da racionalidade moderna centrada na autonomia do sujeito que rompe com os finalismos religiosos. Para o sociólogo francês Alain Touraine:

A ideia de modernidade substitui Deus no centro da sociedade pela ciência, deixando as crenças religiosas para a vida privada [...] Em todos os casos, porém, ela fez da racionalização o único princípio de organização da vida pessoal e coletiva, associando-a ao tema da secularização, isto é, do desvinculamento de toda a definição dos 'fins últimos'. (TOURAINE, 1997, p. 18).

A modernidade consiste, portanto, nesta virada histórica, caracterizada por um movimento crescente de racionalização e desencantamento, como comenta Weber:

A intelectualização e a racionalização crescentes não equivalem, portanto, a um conhecimento geral crescente acerca das condições em que vivemos. Significam, antes, que sabemos ou acreditamos que, a qualquer instante, poderíamos, bastando que o quiséssemos, provar que não existe, em princípio, nenhum poder misterioso e imprevisível que interfira com o curso de nossa vida; em uma palavra, 
que podemos dominar tudo, por meio da previsão. Equivale isso a despojar de magia o mundo. Para nós não mais se trata, como para o selvagem que acredita na existência daqueles poderes, de apelar a meios mágicos para dominar os espíritos ou exorcizá-los, mas de recorrer à técnica e à previsão. Tal é a significação essencial da intelectualização. (WEBER, 2005. p. 30-31)

Independentemente das particularidades dos pensamentos de sociólogos que se dedicaram a elaborar sobre o processo de secularização (além de Weber, Marx e Durkheim aparecem como notáveis pensadores fundacionais do tema), é possível dizer que nenhum deles deixou de apontar para certa incompatibilidade entre religiões tradicionais e sociedades modernas.

Em abril de 1906, Max Weber havia sido convidado para proferir uma conferência em Stuttgart, por ocasião do 9ํㅡㄹ Congresso dos Historiadores Alemães. O objetivo do encontro era discutir a importância do protestantismo na origem e no desenvolvimento do mundo moderno. Contudo, por questões de saúde, Weber não pôde participar do evento. O sociólogo então recorreu ao amigo teólogo Ernst Troeltsch (1865-1923), também professor da Universidade de Heidelberg, para que o substituísse na conferência. Três meses depois da realização do congresso, a conferência de Troeltsch foi publicada pela HistorischeZeitschrift, sob o título $O$ significado do protestantismo para a origem do mundo moderno.

Já na introdução do livro, Troeltsch destaca a importância da substituição do termo "mundo moderno", universalizante em sua essência, por "civilização moderna", mais apropriada para tratar dos tópicos da modernidade em uma perspectiva recortada temporal e territorialmente, considerando que este conceito deveria ser usado para os fenômenos ligados especialmente à Europa e aos Estados Unidos. É neste contexto, pois, que ele considera o protestantismo como um dos ancestrais da chamada civilização moderna, apresentado sob quatro características principais, resumidamente:

i) Uma oposição à ideia de civilização submetida aos paradigmas da Igreja Católica, a partir da elaboração de ideais que promovam a capacidade autônoma no pensamento crítico dos indivíduos. 
ii) Valorização do pensamento científico independente da revelação e da tutela eclesial. No lugar de um saber orientado pelo sagrado, começou a predominar uma literatura baseada em métodos cada vez mais rigorosos e autossuficientes.

iii) Um crescente interesse pelo mundo extra-místico e pela vida presente, responsabilizando os "homens" pelos seus próprios atos e escolhas, em oposição ao declínio do pensamento da predestinação divina.

iv) Em consonância com esta última característica, verificam-se um otimismo autoconfiante e uma crença no progresso, a partir da autonomia do pensamento crítico e o desenvolvimento científico. As tradicionais concepções cosmogônicas, que eram dominadas pelas doutrinas do pecado original, do juízo final, da redenção do homem e da consumação do mundo, viram seus fundamentos abalados ou postos em questão.

Embora Troeltsch reforce em suas elaborações que o protestantismo é o solo sobre qual brotou e se desenvolveu o mundo moderno, ele não deixa de reconhecer que os fatores responsáveis por esta eclosão mergulham suas raízes mais profundamente, para além da própria Reforma Protestante, indo além do Renascimento, e mesmo da Idade Média. Foi, contudo, a partir deste pano de fundo moderno - conclui Troeltsch - que se desdobrou e se intensificou o racionalismo individualista da modernidade.

O individualismo moderno não está, em primeiro lugar, baseado no Renascimento, mas antes na ideia essencialmente cristã do destino do homem para adquirir uma personalidade completa através da ascensão para Deus como fonte de vida, tanto da pessoa quanto do mundo (...) Este, no entanto, não deriva do criticismo e da emancipação intelectual, mas mergulha suas mais profundas raízes numa metafísica e numa ética que foram fundamentalmente implantadas no espírito de toda a nossa civilização moderna pelo cristianismo. (TROELTSCH, 1986, p. 30 e 31)

Mesmo que a modernidade tenha sido delineada, em última instância, em oposição a um modelo de sociedade ordenado a partir da religião - a qual foi fortemente associada ao tradicionalismo, obscurantismo e autoritarismo - esse lugar 
simbólico é instável e contingente, e as relações entre modernidade e religião podem assumir configurações bastante diversas, de acordo com os desdobramentos que ocorrem no contexto social e cultural. Essa instabilidade do conceito de modernidade (e também de aspectos ligados a ela, como a secularização) nos direciona para o entendimento deste tema a partir de perspectivas menos pragmáticas. Assim, abrimos espaços para questionamentos às programáticas teorias da secularização -- e à própria ideia de "desencantamento do mundo" proposta por Weber.

Para o antropólogo brasileiro Emerson Giumbelli, a separação dicotômica Religião/Estado, trazida por uma perspectiva secularizadora e resultante da formação da ideia de Estado laico, não obstante, trouxe em seu núcleo a seguinte questão: "não deixa de ser paradoxal que a mesma modernidade que exigiu a separação entre Estado e igrejas, governo civil e religião, também instituiu a liberdade religiosa" (GIUMBELI, 2004, p. 48). Neste caso, a laicidade pretendida pelas sociedades modernas tem, em si, a questão ainda não resolvida sobre o espaço do religioso na sociedade. O paradoxo reside, portanto, no fato de que a modernidade combina a perda da influência dos grandes sistemas religiosos e a recomposição, sob uma forma nova, das representações e manifestações desses sistemas.

As recentes revisões históricas da modernidade trazem, em seu núcleo de discussões, a impertinência de uma leitura homogênea sobre tal conceito, especialmente quando consideramos as diferentes e permeáveis faces que a modernidade foi desenvolvendo em contextos sócio-culturais específicos. É nesse mesmo sentido que as teorias da secularização também perdem sentido, pois a ideia de um enfraquecimento da religião no bojo da racionalidade moderna não se efetivou. Ao contrário disso, assistimos a um crescente movimento de adesão às manifestações religiosas, dessa vez em um contexto de pluralismo religioso.

Há, portanto, na contemporaneidade, impasses no âmbito sociológico acerca das elaborações dos conceitos de secularização e dessecularização, visto que esses são processos em progresso, inacabados e dialéticos. Inúmeros sociólogos defendem que a religião vem perdendo a sua influência nas mais diferentes esferas sociais e no espaço público. Contrariamente, porém, outros tantos defendem que na sociedade contemporânea há uma tendência dessecularizante com o crescimento 
do religioso. Este último aspecto tem recebido o nome de "reencantamento do mundo", por alguns sociólogos da religião.

A crítica desencadeada pelas análises pós-secularistas ressalta que os próprios discursos hegemônicos sobre modernidade, em perspectiva ocidentalizada, estão muito mais atravessados por valores, categorias e lógicas enunciadas a partir do religioso do que poderiam admitir as perspectivas (des)secularistas. Diversas análises dos fenômenos sócio-políticos contemporâneos vêm evidenciando o quanto noções como "universalidade", "liberdade", "confiança”, "emancipação" e até mesmo a "secularização" estão profundamente enraizadas nas tradições teológicas do cristianismo e/ou das grandes religiões monoteístas - ou "abraâmicas", como comenta o filósofo franco-magrebino Jacques Derrida.

Sem a experiência performativa deste ato de fé elementar, não haveria nem "vínculo social", nem endereçamento ao outro, nem performatividade em geral: nem convenção, nem instituição, nem Constituição, nem Estado soberano, nem lei, nem, sobretudo, aqui, esta performatividade estrutural da performance produtiva, que liga desde o início o saber da comunidade científica ao fazer, e a ciência à técnica. (...) Este ato de fé elementar sustenta também a racionalidade essencialmente econômica e capitalística do tele-tecnocientífico. (DERRIDA, 2000, p. 37)

É nesse contexto de "reencantamento do mundo", contrapondo (ou se desdobrando) às perspectivas weberianas, que as religiões pentecostais - e também o islamismo - ganham força e crescem exponencialmente em todo o mundo, especialmente em regiões periféricas. O protestantismo, ao se manifestar contemporaneamente nos segmentos neopentecostais, apresenta sua face mais dinâmica e permeável para adaptar-se ao mundo liberal moderno. Para o sociólogo da religião Lísias Nogueira Negrão:

As análises de Weber foram válidas para um período encerrado da história do Ocidente: o apogeu da racionalidade num mundo desencantado, em que o sagrado se exilou. Mais recentemente vivemos o período do chamado 'retorno do sagrado' ou 'revanche de Deus', em que este mundo, de alguma forma, se reencanta. Mesmo se considerarmos a realidade do Terceiro Mundo em geral e do Brasil em particular, em que o sagrado persistiu, é inegável que a religião aí se revitalizou, paralelamente ao 
reencantamento primeiro-mundista. (NEGRÃO, 1994, p. 134)

Diante dessa contextualização histórica, articulando aspectos da modernidade com a promoção de valores que favoreceram o desenvolvimento das religiões pentecostais e neopentecostais, é importante ressaltar que tais segmentos religiosos não se manifestam apenas como sintoma das rupturas que as noções modernas desencadearam nas sociedades tradicionais, mas, sobretudo, se estruturaram no imbricamento anacrônico das perspectivas da tradição com as projeções do mundo moderno.

As periferias das grandes cidades brasileiras, originadas pelo fenômeno da migração rural-urbana que marcou o século $X X$, têm sido, desde então, territórios inventivos de práticas culturais de resistência e articulação entre a novidade e a conservação. O pentecostalismo aparece, portanto, como a mais pertinente alternativa à demanda religiosa dos migrantes sobre uma nova expressão mística que não abandonasse por completo traços da religiosidade tradicional.

\subsection{Modernidades na arte e religião no Brasil: o pentecostalismo e o} modernismo brasileiro

Como vimos nos capítulos anteriores, o crescimento do protestantismo no Brasil - sobretudo através da expansão pentecostal - se situa no contexto de desenvolvimento das cidades a partir do século XX, e se dá através de substanciais transformações sociais, culturais e econômicas que esse processo acarretou. Podemos dizer que as grandes cidades brasileiras foram erguidas sobre a estrutural influência religiosa na nossa cultura (especialmente das tradições católicas herdadas do processo de colonização), mesmo tendo sido constituídas no âmbito moderno de valorização da racionalização imobiliária do espaço, que dá às estruturas arquitetônicas - e à própria paisagem urbana - uma fisionomia dessacralizada (ELIADE, 1992). O sagrado, em suas concepções estéticas e conceituais, foi adaptando-se às fissuras do desenvolvimento urbano, reterritorializando-se com o conjunto heterogêneo da cultura moderna, até compor, 
hibridamente, representações e práticas a partir de resíduos da tradição e emergências das culturas de massa.

Embora os estudos sobre a modernidade apontem sempre para instabilidade dos termos, o que tem ocorrido na formação das maiores cidades brasileiras, segundo alguns sociólogos, é um certo anacronismo de aspectos ligados à modernização no Brasil, com a convivência de manifestações que podem ser consideradas pré-modernas, modernas e até pós-modernas. Nesse contexto sóciocultural emergente da primeira metade do século XX, se localiza tanto a expansão do pentecostalismo no país quanto o surgimento do programa estético e cultural do modernismo brasileiro. Ambos os eventos se constituem no âmbito do encontro friccionado entre a cultura de massa moderna com os tradicionais esquemas culturais de raízes rurais.

Não sendo o movimento modernista objeto central desta investigação, busca-se, nessa parte introdutória e contextual sobre o tema das representações evangélicas na arte contemporânea brasileira, elaborar paralelos históricos e confluências que tenham favorecido o desenvolvimento das manifestações modernas no âmbito religioso e artístico no país. Para isso, situo ambos os projetos - de expansão pentecostal e modernismo brasileiro - como sintomas circunstanciais de um desejo de modernização. Sobre o fenômeno social moderno brasileiro, o sociólogo José de Souza Martins comenta:

(...) na sociedade brasileira, a modernização se dá no marco da tradição, o progresso ocorre no marco da ordem. Portanto, as transformações sociais e políticas são lentas, não se baseiam em acentuadas e súbitas rupturas, sociais, culturais, econômicas e institucionais. O novo surge sempre como um desdobramento do velho. (MARTINS, 1999, p. 30)

A expansão das igrejas evangélicas por todas as regiões do Brasil durante o século XX está circunscrita, portanto, nessa conjuntura do início de transição da predominância da população rural para urbana. A relação do pentecostalismo com a modernização das metrópoles brasileiras se desenvolve no contexto (e através dele) paradoxal da modernidade: as cidades modernas, superracionalizadas, não extinguem os resíduos de uma sociedade estruturalmente religiosa. Diante dessas 
especificidades dos paradigmas modernos no contexto do crescimento pentecostal brasileiro, o sociólogo João Décio Passos atenta:

A passagem do rural ao urbano expõe estas especificidades de modo emblemático quando acirra o descompasso entre um longo período rural e uma rápida metropolização. O pentecostalismo emerge no interior deste processo, como metáfora da contradição entre passado e presente e, portanto, com cara sempre mais brasileira. A consciência de nossas contradições históricas e peculiaridades culturais nos coloca numa postura de crítica dos paradigmas do desencantamento-e-reencantamento e de seu uso na explicação do crescimento quantitativo e qualitativo dos grupos pentecostais e mesmo de outros grupos religiosos. (PASSOS,2000)

Sobre a convivência de aspectos religiosos e seculares no projeto de modernização do Brasil, é oportuno ressaltar presença significativa de símbolos cristãos na concepção "moderna" da capital brasileira. A Catedral Metropolitana Nossa Senhora Aparecida, conhecida como Catedral de Brasília (que comemorou 50 anos em 2020), é um marco da arquitetura moderna e foi o primeiro monumento criado no audacioso projeto de Oscar Niemeyer. No interior da Catedral, na parede do coro, veem-se instalados 15 painéis de Di Cavalcanti, representando a Via Sacra e, em uma coluna triangular, 7 quadros de Athos Bulcão, retratando a vida da Virgem Maria. Tanto Bulcão quanto Cavalcanti se notabilizaram como expressivos nomes da arte moderna no Brasil, junto a artistas e intelectuais de diferentes linguagens, com destaque nas artes plásticas para Anita Malfatti, Candido Portinari, Tarsila do Amaral, Vicente do Rego Monteiro, Inácio da Costa Ferreira, John Graz, Oswaldo Goeldi, Victor Brecheret e Wilhelm Haarberg.

Nos primeiros momentos do modernismo no Brasil, iniciado por volta de 1917, o que se pretendia era criar uma renovação nas artes nacionais. A estratégia representou um esforço coletivo e organizado de superação de aspectos academicistas em diversas expressões artísticas, chamadas pelos nossos modernistas de "passadismo". A preocupação principal do modernismo era, portanto, realizar uma renovação estética a partir de um olhar simultaneamente retrospectivo e prospectivo para a cultura nacional e as práticas artísticas. O marco 
simbólico deste projeto foi a Semana de Arte Moderna, realizada na cidade de São Paulo em fevereiro de 1922 e considerada um divisor de águas na história cultural e artística brasileira. O evento - organizado no mesmo ano do Centenário da Independência do Brasil- declara o rompimento com o tradicionalismo cultural, associado às correntes literárias e artísticas anteriores: o parnasianismo, o simbolismo e, como já mencionado, a arte acadêmica, propondo um programa de investigação estética popular, a atualização da idiossincrasia artística e cultural brasileira, e a instauração de uma consciência crítica e criativa nacional original. Contudo, esse programa cultural e estético de caráter nacional proposto pelo modernismo brasileiro foi elaborado, paradoxalmente, a partir de "estrangeirismos".

A historiadora e crítica de arte Aracy Amaral, sobrinha da pintora modernista Tarsila, ressalta que "No Brasil, internacionalismo e nacionalismo foram simultaneamente as características básicas do movimento modernista ocorrido nas letras e artes a partir de meados da segunda década do século passado" (AMARAL, 2012, p. 11). Eis mais um possível paralelo entre o projeto modernista e o fenômeno pentecostal no Brasil. Porém, nesse caso, sublinho o movimento inverso em relação à influência estrangeira nessas manifestações. Enquanto no modernismo brasileiro as referências de culturas ádvenas são processadas e incorporadas para a criação de um programa genuinamente brasileiro, o pentecostalismo, nascido do protestantismo estadunidense, ganha ao chegar no Brasil características territoriais, sem jamais se emancipar por completo de sua ligação originária com a cultura norte-americana.

Em 1928, ainda na esfera do programa modernista, foi lançado o Manifesto Antropófago, elaborado pelo escritor paulista Oswald de Andrade. O texto proposto por Oswald (e publicado na primeira edição da Revista de Antropofagia) concatenava, em uma linguagem simbólica, as ideias de modernidade assimiladas pelo escritor após suas recentes passagens pela Europa. A proposta da antropofagia cultural de Oswald de Andrade promovia, em termos gerais, a ideia de incorporar criticamente a cultura estrangeira enquanto alimento transformado a partir de uma prática criadora local. Essa metáfora indigenista propunha que a influência cultural de outros países deveria ser devorada, deglutida e regurgitada em potencial criativo original brasileiro. Assim, a arte brasileira contaria com esses elementos, ressurgindo não como um mero reflexo cultural externo, mas como uma identidade brasileira multicultural e particular. 
Em sua abordagem descolonial, o Manifesto Antropófago de Oswald de Andrade propõe uma leitura contra-hegemônica (termo muitas vezes mencionado nas abordagens mais contemporâneas dessa pesquisa) sobre as heranças culturais do Brasil. Um gesto performático de ruptura com toda a passividade que imperava na relação do país com sua própria história. A iconoclastia antropofágica traduz, em certo sentido, um sentimento candente do início do século XX no Brasil, de possibilidade de futuro fora da perspectiva submissa de território colonizado. Esse pensamento se manifestava na forma de questionamentos sobre um certo establishment cultural brasileiro. O repertório católico colonial era frontalmente provocado pela perspectiva oswaldiana, evidenciando a perda de centralidade do catolicismo como elo de identificação nacional. "Só a ANTROPOFAGIA nos une. Socialmente. Economicamente. Filosoficamente." diz os versos iniciais do manifesto de 1928. A antropofagia aparece então como "absorção do inimigo sacro" (ANDRADE, 1976). Não se trata de rejeitar todos esses símbolos, mas absorvê-los e transformá-los.

Embora bastante desgastado pelo seu status canônico, o tema da antropofagia continua sendo um importante conceito-chave nas investigações sobre uma suposta identidade nacional brasileira. Para esta pesquisa, interessa menos discutir o cânone do conceito ou mesmo a pertinência da busca de um programa nacionalista a partir das artes. Concentro-me em abordar a perspectiva antropofágica como devoração do Outro no entendimento da experiência humana enquanto busca e incorporação constante do não-eu, da diferença, ou seja, do exercício da alteridade como construção de subjetividades, sejam individuais ou coletivas. É claro que, pelo recorte temático desse estudo, faço essa operação com vistas a compreender também aspectos do fenômeno pentecostal brasileiro. Nesse sentido, a operação antropofágica me serve como um parâmetro de diferença entre as relações de interioridade e exterioridade propostas pelos diversos programas estéticos que circularam no âmbito do modernismo brasileiro e o desenvolvimento pentecostal no país.

É frequente - e crescente - desde, pelo menos, o advento neopentecostal manifestações culturais e artísticas no seio das comunidades evangélicas produzidas a partir de encontros sincréticos e híbridos com símbolos da cultura popular brasileira. Festas juninas sem odes aos santos católicos, blocos de carnaval com restrições à sexualidade, capoeira gospel com hinos cristãos ao invés de 
cânticos afro-brasileiros, festas de música eletrônica com condenação ao uso de entorpecentes são alguns desses exemplos. Isso sem falar nas incorporações de superstições herdadas de religiões e misticismos tradicionais: amuletos, objetos sagrados, flores, água benzida (orada ou ungida, na terminologia pentecostal). São inúmeras as formas de apropriação de elementos seculares ou até mesmo de outras religiões dentro da cultura evangélica.

Essa assimilação de símbolos e manifestações externas pelo pentecostalismo brasileiro pode ser considerada um tipo de antropofagia cultural, à medida que apropriamos o conceito modernista ao contexto evangélico como uma deglutição de códigos que são estrangeiros às tradições protestantes, resultando em manifestações originais constituídas por hibridismos e sincretismos. Sabemos que essa operação de absorção de elementos de outras culturas em perspectiva da constituição de uma nova manifestação cultural ou religiosa não é exclusiva das igrejas pentecostais. A própria Umbanda, considerada uma religião essencialmente brasileira, surge contemporaneamente ao pentecostalismo, em 1908, a partir da amálgama de várias expressões das religiões africanas, indígenas e cristãs, porém se constituindo como um novo segmento religioso.

Há, contudo, neste movimento de apropriação estabelecido pelas igrejas pentecostais - e, sobretudo, neopentecostais - uma forte marca de dessecularização ou conversão dos elementos incorporados. É sobre esse aspecto que proponho um contraponto para os entendimentos do conceito antropofágico associado ao modernismo brasileiro e ao movimento pentecostal. O poeta concretista Haroldo de Campos, herdeiro direto do programa estético e cultura modernista, destaca o aspecto insubmisso da elaboração oswaldiana

A "Antropofagia" oswaldiana [...] não envolve uma submissão (uma catequese), mas uma "transculturação"; melhor ainda, uma "transvaloração"; uma visão crítica da história como função negativa (no sentido de Nietzsche), capaz tanto de apropriação como de expropriação, desierarquização, desconstrução. (CAMPOS, 1992, p. 234-235)

A este processo de deglutição pentecostal chamarei "antropofagia da conversão", pelo qual religiosos evangélicos expropriam elementos seculares ou vindos de outras religiões e ressaltam aspectos estranhos às origens dessas 
manifestações, fundando um novo tipo de colonização cultural. Movimento, portanto, mais próximo à catequização, como menciona Campos, do que da "transvaloração" antropofágica.

Um fato emblemático que permite o emprego do conceito de "antropofagia da conversão" vem acontecendo desde a segunda década dos anos 2000, na cidade de Salvador, Bahia, com os bolinhos de acarajé ${ }^{10}$ e seu tombamento como patrimônio nacional através do Instituto do Patrimônio Histórico e Artístico Nacional (IPHAN). O saber reconhecido pelo Ministério da Cultura, em 2004, como patrimônio cultural imaterial refere-se ao ofício das "baianas do acarajé", cujo início da produção do prato tem como base de receita um bolo de feijão fradinho frito no azeite de dendê. A técnica de feitura do acarajé representa um modo de fazer enraizado no cotidiano dos seus produtores, seja para uso religioso, alimento sagrado oferecido às divindades nos rituais do candomblé, seja para uso profano, comercializado nas ruas pelas baianas.

A crescente conversão de baianas do acarajé às igrejas neopentecostais implicou em um movimento, por parte de um grupo de recém-convertidas, de dissociação do famoso bolinho com seu sentido cultural e religioso originário, eliminando os rituais que antecediam sua venda, retirando os símbolos que enfeitavam o tabuleiro e as próprias baianas, mudando o nome africano do prato tradicional para "bolinho de Jesus". Para conter esse processo de "conversão cultural" foi necessária a intervenção de uma lei municipal, que garantia a obrigatoriedade dos trajes típicos para a sua comercialização em espaços públicos.

O caso dos bolinhos de acarajé baianos denota aspectos divergentes das antropofagias propostas pelo movimento modernista brasileiro em relação à praticada pelo neopentecostalismo. Enquanto no programa do modernismo oswaldiano a apropriação de estrangeirismos e assimilação de outras culturas servem de suportes para uma criação artística-estética dialética/dialógica, parte significativa dos religiosos evangélicos fazem essa expropriação anulando os sentidos conflitantes inerentes de tais elementos, com firme oposição aos valores culturais de práticas culturais que diferem da epistemologia cristã. Ou seja, o sentido último dessa operação cultural não é assimilação e sim a conversão de valores.

É importante ressaltar que, ao especular um paralelo entre aspectos do modernismo e do pentecostalismo brasileiro, faço isso menos comprometido com

\footnotetext{
${ }^{10}$ http://www.palmares.gov.br/?p=16377
} 
uma abordagem historiográfica e mais como um exercício de relacionar ideias centrais dos dois programas, a fim de identificar uma possível gênesis do lapso das representações sobre os símbolos evangélicos na arte brasileira, especialmente no âmbito moderno. Nesse sentido, o conceito da antropofagia que aparece como suporte de parâmetro de contrastes entre os dois objetos, considerando que os diferentes sentidos da relação com o Outro - na perspectiva de conformação ou fortalecimento de uma identidade - distância substancialmente as agendas pentecostalistas e modernistas.

Embora o modernismo, considerando o grupo a frente dos eventos ligados à Semana de 22, tenha proposto um programa intelectual e estético "deselitizante", a popularização de suas manifestações, elaboradas e promovidas no contexto da elite latifundiária paulistana, ficou mais circunscrita às representações dos elementos da cultura popular do que propriamente à reconfiguração do quadro artístico e intelectual no Brasil. Ao contrário disso, o projeto bem sucedido do modernismo brasileiro se dá, justamente, pelo estabelecimento de um novo cânone estético e artístico nas artes brasileiras.

Os limites do projeto modernista, bem como a pertinência de suas terminologias, o questionamento sobre seus marcos temporais, sua amplitude sóciogeográfica, e relação com o circuito institucionalizado, é tema recorrente nas revisitações acerca do movimento. Tais tensionamentos, contudo, deflagram a vitalidade persistente e centralidade desse tema para a arte e a cultura do país. Menos interessado em elucidar esses impasses, recorro a abordagem de Pierre Bourdieu sobre a postura da arte moderna justamente como uma luta permanente entre os membros do campo artístico pelo direito de impor sua própria definição do que é arte e de quem é artista (Bourdieu, [1992] 1996, p. 255-281).

Portanto, pensando em uma perspectiva de proposições de projetos nacionais, o modernismo brasileiro diferencia-se estruturalmente do pentecostalismo por se tratar de uma agenda essencialmente burguesa, engendrada como disputa de poder sobre símbolos que estão historicamente distantes do domínio das camadas mais populares do país. Enquanto isso, o movimento pentecostal, por ter se desenvolvido subterraneamente a todos os focos de interesse de representação das tradições brasileiras, conseguiu aprofundar suas raízes de contato com os setores mais periféricos da sociedade brasileira, estabelecendo uma nova relação 
entre tradição e progresso, sempre tendo as demandas desses sujeitos subalternizados como foco de absorção.

Essa capacidade comunicativa, articuladora e mobilizadora das igrejas evangélicas tem promovido a íntima relação do pentecostalismo com a ampla camada mais pobre da população brasileira. Em outro sentido, o circuito institucionalizado das artes no país, que tem suas origens na perspectiva modernista e sua consolidação formal com a construção dos equipamentos de arte moderna na década de 40, tem se desenvolvido com marcações muito firmes de posições de poder. Esses posicionamentos permanecem firmes, mesmo com 0 advento da arte contemporânea e todo o esforço experimental por uma arte menos canônica (e canonizada). Apenas nas primeiras décadas dos anos 2000 os códigos e símbolos evangélicos começaram a aparecer como consistente repertório de pesquisa de artistas contemporâneos. Veremos, adiante, que isso também tem a ver com uma mudança do quadro de artistas que começaram a circular no circuito institucional das artes.

Considerando a arte contemporânea um segmento artístico de domínios cada vez menos catalogáveis e mais abrangentes, essa pesquisa lançará mão de um repertório de referências artísticas que não estão circunscritas ao universo das artes visuais, propondo diálogos com o carnaval, com a cena musical brasileira e também outras manifestações que podem estar fora do ambiente artístico institucionalizado. 


\section{CAPÍTULO 3: O CRISTO EVANGÉLICO NA ARTE CONTEMPORÂNEA}

\subsection{Exposição Renovação Carismática}

Em fevereiro de 2019, foi inaugurada no espaço cultural Caixa Preta, localizado em Botafogo, na Zona Sul do Rio de Janeiro, a exposição coletiva Renovação Carismática, sob curadoria de Rafael Bqueer e Vinícius Monte e colaboração curatorial de Gustavo Barreto. Considero que meu contato com este projeto teve um papel fundamental como provocação inicial para a elaboração desta pesquisa de dissertação. Conforme sugere o próprio título da mostra, não se tratava de um recorte específico sobre representações evangélicas na arte contemporânea, mas buscava "articular trabalhos de artistas que investigam o Brasil contemporâneo em sua dimensão religiosa e suas insurgências no campo político e interferências no campo da arte" ${ }^{\prime 11}$. Sendo assim, a exposição destacou a emergência evangélica na cultura (e na sociedade, de maneira geral) brasileira.

A mostra se estabeleceu, embora com pouco destaque pela crítica de arte e discreta divulgação midiática, como marco precursor de uma abordagem curatorial sobre símbolos evangélicos nas artes visuais. É representativo que o projeto tenha sido realizado por um espaço cultural independente, focado na produção de jovens artistas emergentes. Embora crescentes nas produções artísticas, especialmente de artistas de origem periférica, os tópicos sobre a cultura evangélica continuam sendo negligenciados-- a despeito de seu protagonismo em vários setores da sociedade brasileira --no âmbito dos temas curatoriais. Sobre esse negligente contato entre as artes visuais e os temas evangélicos, os curadores se manifestam:

Nos perguntam sobre o posicionamento da arte frente o crescimento significativo de igrejas nas periferias $e$ subúrbios do país. Exclusão ou problematização?

A renovação carismática dos movimentos pentecostalistas é celebrada enquanto presença alegórica. A cruzada feita para garantir a ordem em torno de uma ideia binária de organização do mundo, levanta questionamento sobre os limites entre o que é sagrado e profano.

\footnotetext{
${ }^{11}$ Trecho do texto curatorial compartilhado no evento de inauguração da exposição no perfil oficial do Caixa Preta no Facebook: https://www.facebook.com/events/366402060851689/.
} 
Participaram do projeto os artistas: André Vargas, Coletivo A Noiva, Bárbara Wagner e Benjamin de Burca, Como Uma Deusa, Guerreiro do Divino Amor, Joãosinho Trinta, Katia Politzer, Maria Amélia Raeder, Marianne Giuliano, Panmela Castro, Renato Atuati e Virginia de Medeiros. Como descrito anteriormente, nem todos os trabalhos traziam como tema central as manifestações pentecostais (embora os símbolos da iconografia evangélica tenham se destacado no conjunto de trabalhos), o que resultou em uma exposição pouco precisa sobre o foco da perspectiva curatorial nas emergências religiosas no Brasil. Imprecisão que, na verdade, se manifesta deliberadamente, já que a escolha do título da mostra denota imediatamente um certo "sincretismo conceitual". Renovação carismática é, afinal, um movimento surgido na Igreja Católica estadunidense, em meados da década de 1960, com a intenção de incorporar ao Catolicismo alguns elementos oriundos do Pentecostalismo Protestante. Mas Max Weber chama a atenção para um uso mais amplo do termo:

(...) carismática em virtude da devoção afetiva à pessoa do senhor e a seus dotes sobrenaturais (carisma) e, particularmente: a faculdades mágicas revelações ou heroísmo, poder intelectual ou de oratória. O sempre novo, o extracotidiano, o inaudito e o arrebatamento emotivo que provocam constituem a fonte da devoção. Seus tipos mais puros são a dominação do profeta, do herói guerreiro e do grande demagogo. A associação dominante é de caráter comunitário, na comunidade ou séquito. São características dela (...) a revelação ou a criação momentânea, a ação e o exemplo, as decisões particulares, ou seja, em qualquer caso (...) o irracional. (WEBER, 2001; p.134-5)

Essa falta de distinção curatorial sobre os símbolos pentecostais em relação às demais narrativas religiosas (considerando que falar sobre emergência religiosa no Brasil contemporâneo, em termos representativos, é quase um pleonasmo de crescimento evangélico), acabou por estimular um exercício pertinente na abordagem sobre esse fenômeno: não é possível isolar o crescimento do pentecostalismo brasileiro de sua relação com outras manifestações religiosas tradicionais do país. A estratégica intenção da diluição desses limites aparece também no texto dos curadores: "Os artistas revelam as contradições dos limites 
polarizantes impostos a sujeitos, objetos que carregam em si mesmos ambiguidades de fronteiras não tão nítidas".

No grupo de artistas que participaram da exposição Renovação Carismática, destaco ao longo dessa dissertação os projetos de: coletivo A noiva, Bárbara Wagner e Benjamin de Burca, Guerreiro do Divino Amor e Virgínia de Medeiros. Mais adiante, obras desses artistas serão articuladas ao trabalho de Ventura Profana - esta sim, uma ausência bastante sentida no conjunto de narrativas artísticas que integraram a exposição no Caixa Preta --, ambicionando projetar um recorte heterogêneo das abordagens dos códigos pentecostais na arte contemporânea brasileira. Hoje, pouco tempo depois (apenas dois anos) da realização da mostra em Botafogo, seria, no mínimo, desatento falar da relação do pentecostalismo no Brasil com as artes visuais sem ao menos citar a obra de Ventura, tamanha projeção que o trabalho da artista baiana tomou no cenário das artes no Brasil.

A escolha dos artistas que compõem essa investigação se deu, principalmente, pelo entendimento que os usos da simbologia e discursos evangélicos em suas obras não são meramente proselitistas ou secundário, e sim fruto de um interesse central nas amplas implicações que o fenômeno do crescimento pentecostal vem provocando no Brasil.

\subsection{Outrxs Cristos}

Por ora, concentro-me em elaborar uma narrativa articulada sobre um trabalho, que --pelo menos para mim -- foi bastante surpreendente (e muito adequado) no contexto da exposição Renovação Carismática. Uma das obras expostas na improvável galeria(adaptada em uma casa de vila vertical) era um registro fotográfico do emblemático desfile da G.R.E.S. Beija-flor de Nilópolis em 1989. O polêmico enredo "Ratos e urubus, larguem a minha fantasia", criado pelo carnavalesco Joãosinho Trinta, marcou história no carnaval carioca como um dos desfiles mais subversivos de todos os tempos.

Após ser proibido de desfilar na avenida a pedido da arquidiocese do Rio de Janeiro, o carro abre-alas "O Cristo mendigo" cruzou a passarela do samba com a imagem da famosa estátua do Cristo Redentor, que inicialmente estaria vestindo 
trajes de mendigo, invólucro em um saco preto. Na frente da imagem, um cartaz pendurado destacava o episódio de censura: "Mesmo proibido, olhai por nós". Na parte de trás da silhueta coberta, uma convocação: "Atenção mendigos, desocupados, pivetes, meretrizes, loucos, profetas, esfomeados e povo da rua... Tirem dos Lixos deste imenso País, restos de luxo e façam a sua fantasia e venham participar deste grandioso Bal Masqué! (Baile de Máscaras)"

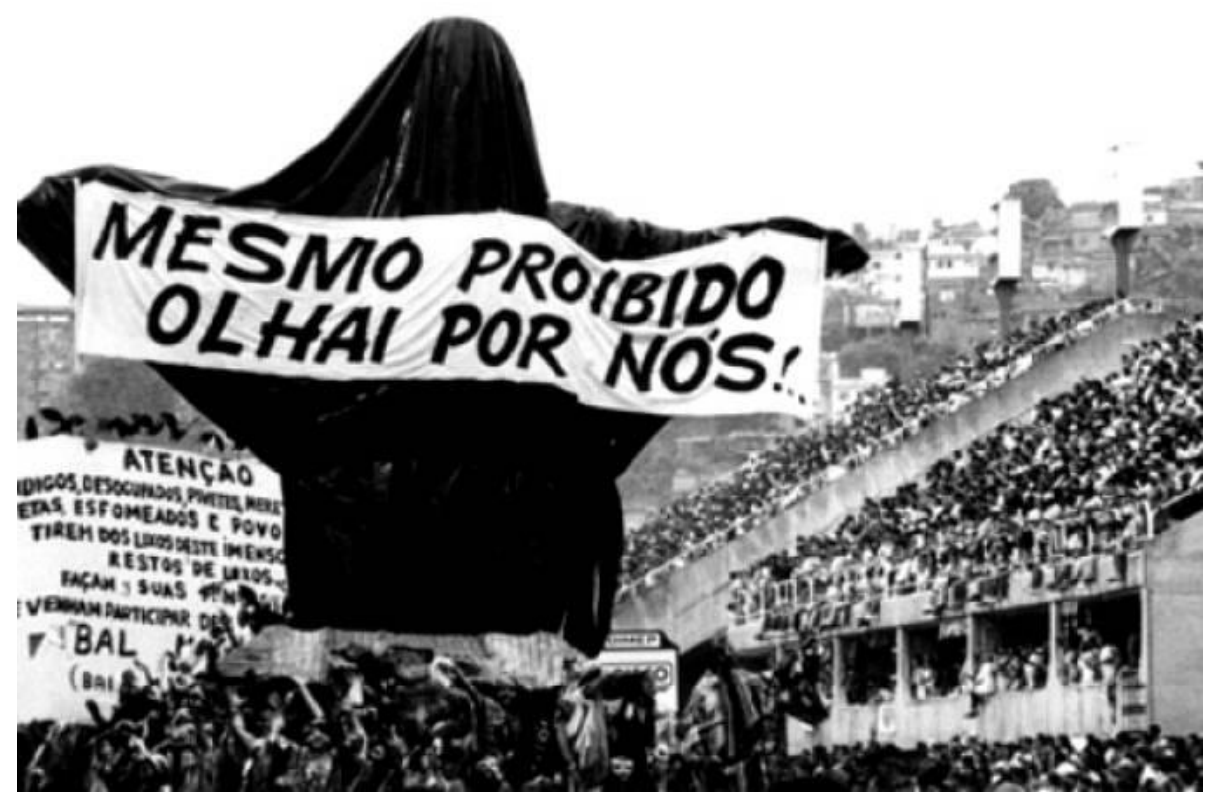

Figura 1 - Alegoria "Cristo mendigo", de Joãosinho Trinta, 1989. Foto: Luiz Caversan/Folhapress/VEJA

Ao decidir mostrar na avenida a escultura estrategicamente encoberta por um plástico preto (e envolta por urubus), o carnavalesco amplia os significados da própria imagem insigne do Cristo. Um gesto ao mesmo tempo artístico, político e poético. A imagem generosa do Cristo Redentor se torna então o estandarte mórbido de um país que insiste em despotencializar a vitalidade de corpos marginalizados, muitas vezes condenando-os à morte. O enredo "Ratos e urubus, larguem a minha fantasia", criado há mais de três décadas, permanece, funestamente, pertinente aos dias de hoje, especialmente neste ano de 2021, marcado pelo cancelamento de uma série de eventos oficiais de carnaval por conta dos trágicos números de mortes causadas pela pandemia do novo coronavírus. 
Em março de 2021, o Brasil ostenta a trágica posição de segundo país com maior número de mortes pela Covid-19 no mundo ${ }^{12}$. A disseminação da pandemia do coronavírus pelas favelas, periferias e interiores do país deflagra, de forma potente, a brutal (e estrutural) desigualdade social e econômica, representando uma barreira às recomendações de higiene básica, distanciamento físico e isolamento social, especialmente para os que vivem em contextos de precariedade. O Conselho Nacional de Saúde (CNS) alerta sobre a necessidade de especial proteção a grupos em situação de vulnerabilidade ou em risco como as pessoas em situação de rua, com sofrimento ou transtorno mental, com deficiência, vivendo com HIV/Aids, LGBTQIA+, população indígena, negra e ribeirinha e trabalhadores do mercado informal, como catadores de lixo, artesãos, camelôs e profissionais do sexo.

O baile de máscaras conclamado pelo carnavalesco Joãosinho Trinta é, na verdade, a folia insurgente de grupos marginalizados pelo processo de colonização, e estigmatizados em um contexto de normatização e subalternização (MIGNOLO, 2003) programática, que se estende aos dias de hoje. Compõem esses grupos, justamente, corpos perseguidos por um dos braços coloniais estruturantes: a Igreja Católica. Para compor a narrativa catequizadora colonial, o Cristo dos relatos históricos, aquele que se associava aos acossados e discursava sobre empatia, tolerância e amor, dá lugar a uma figura excludente e virulenta, formatada para a manutenção do projeto hegemônico de poder eurocêntrico. Sob o nome deste Cristo colonial ainda se pratica sistematicamente a intolerância aos subalternizados, perpetuando a violência física e simbólica a esses grupos. Agora, porém, com atualizados contornos pentecostalistas.

A disputa de narrativas sobre a figura de Jesus Cristo, no contexto das escolas de samba cariocas, foi marcada por um novo episódio emblemático, trinta e um anos depois de Joãosinho Trinta desfilar seu Cristo Mendigo na Sapucaí. Em 2020, a G.R.E.S. Estação Primeira de Mangueira, uma das mais tradicionais agremiações do Rio de Janeiro, apresentou o enredo "A verdade vos fará livre", elaborado pelo premiado e jovem carnavalesco Leandro Vieira. A Mangueira havia sido campeã no ano anterior, sob o comando do mesmo Leandro, com um desfile que apresentava um alto teor político. O enredo "Histórias para ninar gente grande" propunha leituras contra-hegemônicas da "história oficial" do Brasil, e trazia uma série de referências a marcos históricos da luta por direitos das chamadas "minorias

\footnotetext{
${ }^{12}$ https://susanalitico.saude.gov.br/extensions/covid-19_html/covid-19_html.html
} 
identitárias" no Brasil, elencando nomes fundamentais do ativismo negro no país, como o da vereadora Marielle Franco, brutalmente assassinada em $2018^{13}$.

Leandro Vieira é artista plástico carioca, formado pela Escola de Belas Artes da UFRJ, atuando no carnaval do Rio de Janeiro desde 2015. À frente dos projetos artísticos da Estação Primeira de Mangueira, conquistou dois campeonatos: em 2016, com "Maria Bethânia - A menina dos olhos de Oyá"; e em 2019, com o já citado "Histórias pra ninar gente grande". O trabalho do carnavalesco tem ultrapassado os limites dos desfiles elaborados por ele. Em 2017, sua produção debruçada sobre a religiosidade popular, base do enredo da Mangueira naquele ano, foi documentada pelo IPHAN na publicação "Arte e Patrimônio no carnaval da Mangueira" e levada ao Paço Imperial do Rio de Janeiro em exposição individual batizada de "Bastidores da Criação - Arte aplicada ao Carnaval". Em 2018, criou a instalação interativa "Carnaval: grito de quê?", desenvolvida em parceria com o artista Ernesto Neto, para a exposição "O Rio de samba: resistência e reinvenção", que ocupou o Museu de Arte do Rio (MAR). Todo esse destaque rendeu a Leandro a indicação ao Prêmio PIPA em 2020. Indicação inédita para um carnavalesco, em um dos prêmios mais importantes das artes visuais do Brasil.

Leandro propunha, em 2020, um tipo de desdobramento de sua pesquisa anterior, desta vez dando um enfoque subversivo ao "Cristo do Vaticano", como o próprio carnavalesco afirmou na época. Novamente, a Mangueira questionava a "História oficial", se contrapondo, audaciosamente, à narrativa hegemônica sobre a figura histórica mais influente de todos os tempos. A motivação de uma releitura histórica sobre Jesus Cristo pela Mangueira estava elaborada como resposta à crescente onda de intolerância religiosa no país ${ }^{14}$, fomentada pela ascensão da

\footnotetext{
${ }^{13}$ Marielle Francisco da Silva, conhecida como Marielle Franco, nasceu no Rio de Janeiro, em 1979. Criada na Favela da Maré, Zona Norte do Rio, atuou como socióloga e política brasileira, filiada ao Partido Socialismo e Liberdade (PSOL). Elegeu-se vereadora do Rio de Janeiro para a Legislatura 2017-2020 com a quinta maior votação. Mulher negra, lésbica e favelada, Marielle defendia pautas ligadas ao feminismo negro, direitos da população LGBTQIA+, e denunciava abusos de poder praticado pelas forças militares do Rio de Janeiro contra moradores de favelas e espaços periféricos. Em 14 de março de 2018, foi assassinada a tiros junto ao seu motorista, Anderson Pedro Mathias Gomes, no Estácio, Região Central do Rio de Janeiro. O crime causou comoção mundial por sua brutalidade e por se manifestar claramente como um ataque à democracia.

${ }^{14}$ Apenas no primeiro semestre de 2019 , houve um aumento de $56 \%$ no número de denúncias de intolerância religiosa em comparação ao mesmo período do ano anterior. A maior parte dos relatos foi feita por praticantes de segmentos religiosos de matriz africana, como a Umbanda e o Candomblé. Os casos são registrados via Disque 100, número de telefone do governo criado em 2011, que funciona 24 horas por dia para receber denúncias de violações de direitos humanos. Entre 2015 e o primeiro semestre de 2019, foram 2.722 casos de intolerância religiosa - uma média de 50 por mês. Estudo publicado pela Comissão de Combate à Intolerância Religiosa (CCIR) aponta que dos 1.014
} 
representatividade de grupos e pautas conservadoras nos âmbitos político e midiático. Esse recrudescimento conservador culminou na eleição do presidente Jair Messias Bolsonaro, um político de extrema-direita, citado no samba-enredo da Mangueira de 2020, dos compositores Manu da Cuíca e Luiz Carlos Máximo, que faz referência ao gesto bélico marcante da campanha presidencial. “(..) Favela, pega a visão / Não tem futuro sem partilha / Nem Messias de arma na mão / Favela, pega a visão / Eu faço fé na minha gente / Que é semente do seu chão (...)".

A biografia do Jesus Cristo proposta por Leandro Vieira, foi transportada para a contemporaneidade, adaptada às realidades dos territórios populares e aproximada à iconografia e vivência de sujeitos periféricos, especialmente negros moradores de favelas do Rio de Janeiro. Conectou-se, por fim, à própria origem popular do Cristo histórico, manipulado, inclusive racialmente, pela narrativa hegemônica euro-ocidentalizada. Se em 1989 o carnavalesco Joãosinho Trinta havia chocado religiosos conservadores com a imagem do Cristo Mendigo revestido de saco de lixo, Leandro Vieira retoma o mártir crucificado, projetando-o em uma escultura de proporções imponentes, como um jovem negro favelado, alvejado por armas de fogo. Tratava-se, no contexto da narrativa iconoclasta da agremiação, de um paralelo entre a crucificação de Jesus e as alarmantes estatísticas sobre a execução da população jovem negra, a principal vítima de homicídios no Brasil ${ }^{15}$."Mas será que todo povo entendeu o meu recado? / Porque de novo cravejaram o meu corpo / Os profetas da intolerância / Sem saber que a esperança / Brilha mais que a escuridão", destaca o samba da Mangueira daquele ano.

atendimentos realizados pelo Centro de Promoção da Liberdade Religiosa \& Direitos Humanos (CEPLIR) no Rio de Janeiro entre abril de 2012 e agosto de 2015: 71\% das denúncias de intolerância religiosa foram feitas por candomblecistas e umbandistas, $8 \%$ por evangélicos e $4 \%$ por católicos.

\footnotetext{
${ }^{15}$ Segundo o Atlas da Violência, levantamento feito pelo FBSP (Fórum Brasileiro de Segurança Pública) em parceria com o Ipea (Instituto de Pesquisa Econômica Aplicada), vinculado ao Ministério da Economia, em 2018, 75,7\% das vítimas de homicídio no Brasil eram negras. No contexto histórico, de 2008 a 2018, o número de homicídios de pessoas negras no país aumentou $11,5 \%$, já entre pessoas não negras caiu 12,9\%. Nesta década, 628.595 pessoas foram assassinadas no país. O perfil das vítimas aponta que $91,8 \%$ eram homens e $8 \%$ eram mulheres. Entre os homens, $77,1 \%$ foram mortos por arma de fogo, enquanto a taxa das mulheres é de 53,7\%. O risco de um homem negro ser assassinado é $74 \%$ maior e para as mulheres negras a taxa é de $64,4 \%$.
} 


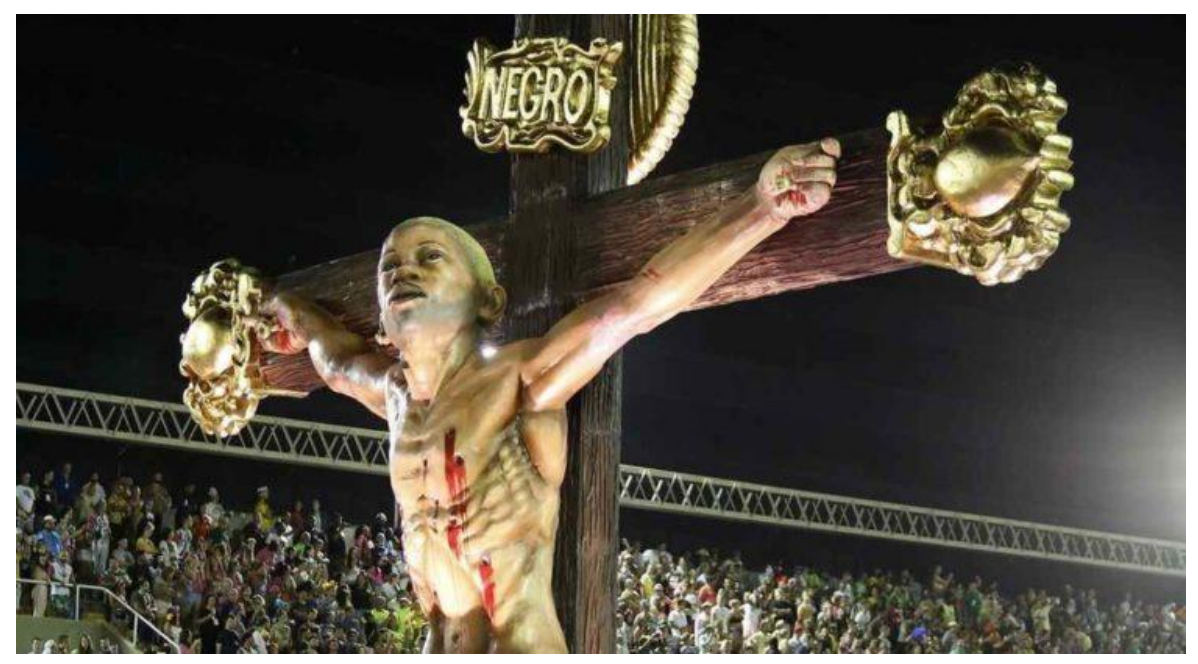

Figura 2- Alegoria "Cristo Negro", de Leandro Vieira, 2020. Foto: Reprodução Rede Globo

Novamente, a abordagem contra-hegemônica causou consternação, especialmente por parte de alguns grupos religiosos conservadores. Contudo, em 2020, o Jesus Cristo negro da Estação Primeira de Mangueira não foi proibido de ser apresentado na avenida, causando apenas reações controversas. Os Cristos de Joãosinho Trinta e Leandro Vieira se conectam, mesmo com o distanciamento de três décadas, ao denunciarem as sistemáticas violências sofridas pelos grupos subalternizados, destacando a condenação letal destes sujeitos (um cristo embalado em um saco preto e o outro cravejado de balas). Se no carnaval da Beijaflor, Jesus suplica, mesmo que coberto, em tom coletivo "mesmo proibido, olhai por nós", o Cristo mangueirense sutilmente olha para o céu, como quem faz uma prece pela visibilidade (divina e social) dos corpos violentados pelo racismo e pela intolerância.

A figura de Jesus Cristo marginalizado também está em destaque na obra do mais importante grupo de rap do Brasil, os Racionais MC's. Fundado em 1988, por Mano Brown, Ice Blue, Edi Rock e KL Jay, os Racionais têm sua origem na periferia da capital paulista, mais precisamente na região do Capão Redondo, considerado na década de 1990 o bairro mais perigoso do mundo ${ }^{16}$. Os Racionais MC's têm como um dos temas principais de suas canções a denúncia de violências sofridas por jovens negros e pobres das periferias brasileiras, como resultado do racismo,

\footnotetext{
${ }^{16}$ Entre os anos de 1996 e 1998, a taxa de homicídio entre homens de 15 e 44 anos era de 241/100 mil habitantes. htps://www1.folha.uol.com.br/cotidiano/2010/04/722049-apontado-como-campeao-dehomicidios-bras-tem-ate-codigo-antifurto.shtml
} 
que sustenta estruturalmente a engrenagem do crime organizado praticado pelo Estado e por grupos paramilitares.

Tendo sido projetada nacionalmente nos anos 1990, a obra dos Racionais MC's se consolidou como importante documento artístico e uma crônica sóciopolítica sobre o crescimento desenfreado das favelas e periferias pelo Brasil no final/início do século, e o consequente agravamento da violência da força do Estado contra os moradores desses territórios. Dentre os tópicos abordados pelos Racionais, frequentemente (e de forma precursora), apareciam referências à simbologia evangélica-pentecostal, incorporadas no sentido de promover um retrato mais fiel possível da realidade periférica brasileira. “(...) Tenha fé, porque até no lixão nasce flor / Ore por nós, pastor, lembra da gente / No culto dessa noite / firmão, segue quente / Admiro os crentes, dá licença aqui / Mó função, mó tabela, pô, desculpa aí (...)". Esses são versos da canção Vida Loka part. 1, lançada no álbum "Nada como um Dia após o Outro Dia" (2002).

Em 1997, outra letra produzida pelos Racionais MC's já deflagrava a influência da simbologia cristã em suas narrativas. A canção "Salve", lançada no álbum "Sobrevivendo ao inferno" (que tem a consagrada capa do crucifixo dourado no fundo preto), trazia os versos: "Ai, tenta a sorte mano, eu acredito na palavra de um Homem de pele escura, de cabelo crespo, que andava entre mendigos e leprosos, pregando a igualdade / Um homem chamado Jesus / Só ele sabe a minha hora / Ai ladrão, tô saindo fora / Paz".

O "Cristo crespo" dos Racionais forma, junto ao "Cristo Mendigo" e ao "Cristo Negro", a tríade contra-hegemônica em relação ao Jesus Cristo euro-ocidentalizado. Em comum aos três, o desejo de associar a luta do mártir cristão à realidade dos grupos marginalizados social, econômica e culturalmente. Esse tipo de operação descolonizadora da figura histórica de Cristo é a força motriz da obra da artista Ventura Profana, peça-chave nesta pesquisa por elaborar -- de forma indissociável entre seu trabalho e a vida -- novas perspectivas de uma espiritualidade cristã, dissidente dos paradigmas católicos, e atualizada na abordagem dos símbolos pentecostais.

3.3. Um problema de representação: conflitos entre a comunidade evangélica e arte contemporânea 
Uma obra de arte é um desafio; não a explicamos, ajustamonos a ela. Ao interpretá-la, fazemos uso dos nossos próprios objetivos e esforços, dotamo-la de um significado que tem a sua origem nos nossos próprios modos de viver e pensar. (HAUSER, 1988)

Podemos dizer que o caráter representacional da arte é uma ideia fundadora da noção de relação da humanidade com as práticas artísticas. As pinturas rupestres, por exemplo, frequentemente retomadas em análises diversas, controvérsias em atestar sobre o caráter artístico dessas manifestações, expõem, ao menos, a disposição pré-histórica do humano para produzir imagens figurativas, buscando representar as coisas que estão no mundo à sua volta.

Sabemos que elaborações sobre imagens desconsiderando o contexto histórico e cultural no qual são produzidas se tornam contraproducentes, visto que a produção imagética foi ganhando diferentes funções ao longo da história. No período pré-histórico, artefatos e imagens sequer foram pensados como arte no sentido elementar, nem sob a nomenclatura artística. Antes, essas produções adquiriam, muitas vezes, um sentido místico que, sob o olhar contemporâneo, posicionam a arte e religião de maneira amalgamada em sua concepção originária.As imagens primitivas estavam ligadas, portanto, a essa última ordem (religiosa)e a relação entre as práticas artísticas antes e depois da era da arte é imensamente descontinua, já que o conceito de arte, tal como pensamos hoje, não estava presente nem na intenção, nem na ideia dessas imagens de devoção - como veio a acontecer muito mais tarde, no Renascimento. Os artistas renascentistas, embora inclinados ao rompimento com a perspectiva teocêntrica que operava todos os campos de expressão e pensamento no período medieval, criaram um repertório de imagens que serviram como suporte para a difusão e consolidação da epistemologia cristã como hegemonia ocidental.

Novos sistemas de produção imagética se desenvolveram no contexto da sociedade pré-moderna do final do século XIX, através do processo de desconstrução dos meios tradicionais de representação - pintura e escultura, tal como os demais materiais e espaços considerados lógicos nas artes plásticas. Dentre essas novas ferramentas, destaca-se o advento da fotografia, importante marco para o reposicionamento da relação das artes com o tema da representação. Ainda assim, essas novas linguagens e ferramentas ainda buscavam 
correspondências no sentido da reprodução sígnica da relação entre o homem, a Natureza e uma determinada visão de mundo representacional.

Para o filósofo Arthur Danto (1997), a mudança do período pré-modernista para o período modernista nas artes pode ser entendida, através da crítica de Clement Greenberg, como uma mudança paradigmática, da pintura mimética para a não-mimética, quando a característica representacional tornou-se secundária. Com isso, destacaram-se outros elementos da produção artística - a tela, o plano e sua bidimensionalidade, o uso de tubos ou potes de tintas, a ausência da perspectiva etc. A partir da compreensão de um possível encadeamento na história da arte, o modernismo torna-se um marco, pois, antes dele, os pintores representavam 0 mundo da maneira como eles o apreendiam, com predominância do sentido visual para captação da realidade. Neste sentido, a pintura não foi vista como um tipo de descontinuidade, como uma representação mimética menos importante do que algum tipo de reflexão sobre outros meios e métodos de representação.

Em 1929, o artista belga René Magritte, expoente nome do surrealismo, fez uma obra fundamental que pavimentou caminhos para um irreversível rompimento do compromisso pré-moderno com o tópico da representação em uma obra de arte. "Ceci n'est pas une pipe" (Isto não é um cachimbo) diz a pintura heterológica que traz o signo iconográfico do cachimbo em destaque no quadro. Magritte nos faz pensar que é sobre as múltiplas formas de representação (e leituras) - e não sobre o objeto do pensamento em si - que incide a obra de arte. É nesse cenário artístico disruptivo da primeira metade do século $X X$ que emergem alguns conceitos que passam a delinear os processos artísticos na contemporaneidade.

Com o surgimento da arte contemporânea a partir dos anos 1960, alguns apontamentos modernos foram explorados em sua radicalidade. Percepções conflitantes da realidade promoveram uma reviravolta no papel da razão na construção do real e da verdade. Nesse contexto, é possível considerar novos balizamentos para o estético e o político, desconstruindo a falsa noção de universalidade fundada em binarismos como: racionalidade e irracionalidade, civilizado e primitivo, masculino e feminino, bem e mal, razão e intuição, etc. Ao reconhecer a importância das contradições, evidencia-se a impossibilidade da verdade universal e celebra-se a diversidade de uma realidade complexa, na qual coexistem múltiplas e conflitantes verdades. 
Esse posicionamento anti-dogmático e subversivo da arte contemporânea, onde a função da obra de arte estaria mais ligada à diluição de fronteiras do que reafirmação de perspectivas; em contraposição aos ambientes religiosos fundamentalistas, marcados, majoritariamente, pela postura catequizadora das subjetividades, confrontam os programas mais evidentes - nos âmbitos das artes e religião - no Brasil. Se, como vimos no capítulo anterior, a arte moderna brasileira não foi capaz de estabelecer relações de troca com as camadas populares de um país que começava a se reconfigurar social, cultural e economicamente, fortalecendo aspectos elitistas dos segmentos artísticos institucionalizados, a produção artística contemporânea inflamou tensões socioculturais de um país crescentemente desigual e polarizado.

São muitos os casos de conflitos de líderes e organizações (neo)pentecostais com projetos artísticos nas últimas décadas. Trago para essa pesquisa dois eventos recentes emblemáticos sobre a rusguenta relação entre arte contemporânea e a comunidade evangélica no Brasil. No cerne das discussões estão os díspares entendimentos de ambas as partes sobre representação, o que implica não apenas na recepção beligerante de parte dos evangélicos a obras de arte que contestam paradigmas cristãos, mas na própria compreensão desses segmentos pelo conceito de arte.

Em 15 de agosto de 2017, o Santander Cultural, localizado em Porto Alegre, inaugurou a mostra Queermuseu - cartografias da diferença da arte brasileira. A exposição coletiva, curada pelo gaúcho Gaudêncio Fidelis, ficaria em cartaz no espaço até o dia 8 de outubro daquele mesmo ano. Acabou sendo fechada às pressas, quase um mês antes do previsto, logo após uma enxurrada de protestos virtuais. O projeto original do Queermuseu reuniu 270 trabalhos de 85 artistas que abordavam as temáticas de gênero e de diversidade sexual. As obras - que percorrem o período histórico de meados do século $X X$ até os dias de hoje - são assinadas por importantes nomes da arte Brasileira como Adriana Varejão, Alfredo Volpi, Cândido Portinari, Fernando Baril, Hudinilson Jr., Lygia Clark, Leonilson, Alair Gomes e Yuri Firmeza. As manifestações contrárias à exposição acusavam que as obras promoviam blasfêmia contra símbolos religiosos e também apologia à zoofilia e pedofilia.

Nas redes sociais, as mensagens e vídeos mais compartilhados pelos críticos e grupos religiosos destacavam a pintura de um Jesus Cristo com vários 
braços, a obra "Cruzando Jesus Cristo Deusa Schiva" (1996), de Fernando Baril; e imagens de crianças com as inscrições "Criança viada travesti da lambada" e "Criança viada deusa das águas" (2013), pintura da artista Bia Leite. As manifestações foram lideradas principalmente pelo Movimento Brasil Livre (MBL) ${ }^{17}$ e recebeu apoio do então prefeito da capital do Rio Grande do Sul, Nelson Marchezan Jr. (PSDB), que pediu o encerramento da exposição.

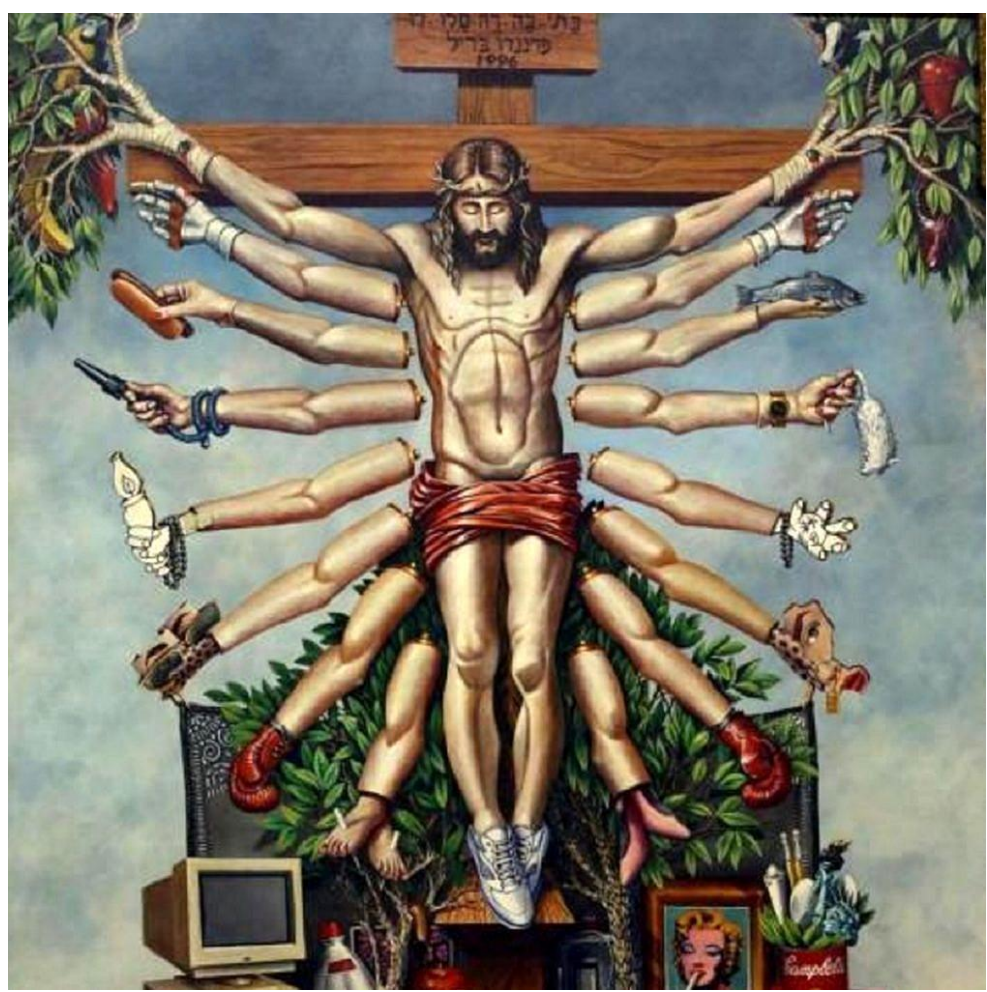

Figura 3 - Obra "Cruzando Jesus Cristo Deusa Schiva", de Fernando Baril, 1996.

17 O Movimento Brasil Livre (MBL) é um movimento político brasileiro que defende o liberalismo econômico e o republicanismo, ativo desde 2014. Em seu manifesto, cita cinco objetivos: "imprensa livre e independente, liberdade econômica, separação de poderes, eleições livres e idôneas e fim de subsídios diretos e indiretos para ditaduras". De acordo com o jornal The Economist, o grupo é composto por aderentes do thatcherismo e foi fundado "para promover respostas do livre mercado aos problemas do país". Para o jornal El País, apesar de sua aparência, a ação do movimento é eminentemente antipetista, aspecto que vem sendo repetidamente notado. $O$ movimento está posicionado à direita do espectro político tradicional. 


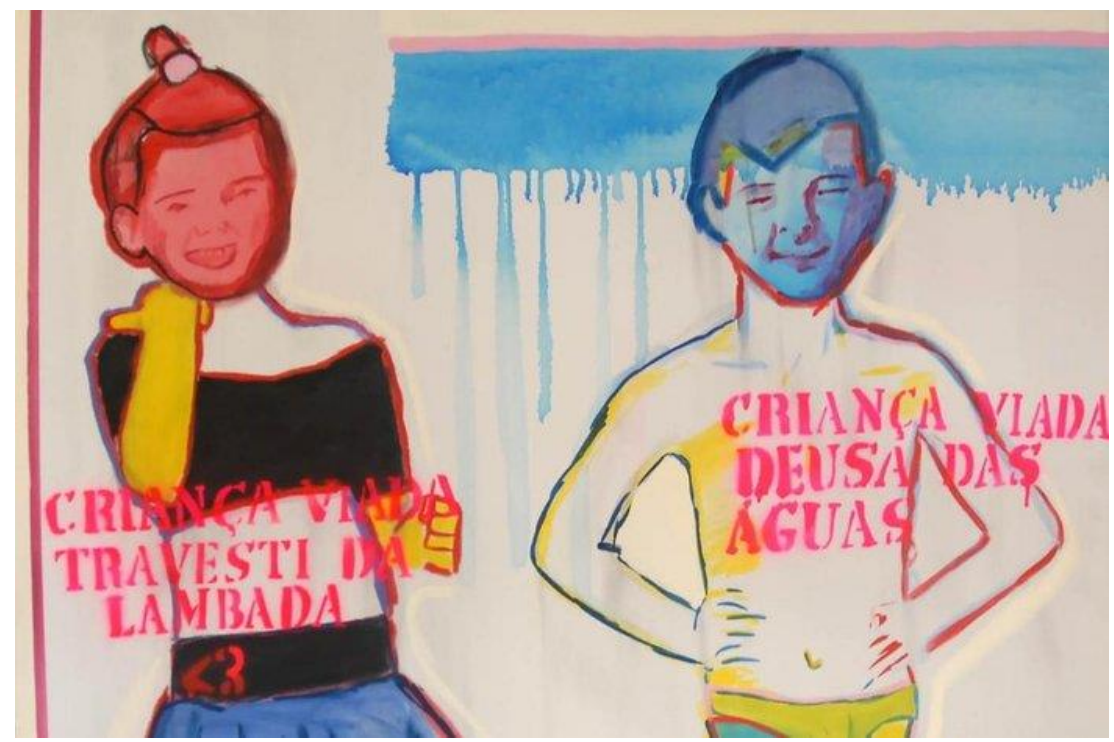

Figura 4 - Obras "Criança viada travesti da lambada" e "Criança viada deusa das águas", de Bia Leite, 2013.

Diante da forte repercussão repentina, em um primeiro momento o Santander esclareceu, por meio de uma nota oficial, que algumas imagens apresentadas na mostra poderiam provocar um sentimento contrário daquilo que pretendiam discutir. No entanto, elas tinham sido criadas "justamente para nos fazer refletir sobre os desafios que devemos enfrentar em relação a questões de gênero, diversidade, violência entre outros". Dois dias depois, entretanto, o banco voltou atrás e cedeu às pressões dos críticos com medo de um forte boicote que gerassem prejuízos à imagem da instituição financeira.

Uma das obras da exposição, Cena de interior /l (1994), pintura da artista carioca Adriana Varejão, foi acusada de apologia à zoofilia ao retratar duas figuras masculinas indistintas com uma cabra. Ao jornal EL PAíS ${ }^{18}$, a artista afirmou que a obra em questão é adulta, feita para adultos. "A pintura é uma compilação de práticas sexuais existentes, algumas históricas (como as Chungas, clássicas imagens eróticas da arte popular japonesa) e outras baseadas em narrativas literárias ou coletadas em viagens pelo Brasil. O trabalho não visa julgar essas práticas", explicou. Adriana é um dos nomes mais representativos na arte brasileira, e tem peças nas coleções de museus internacionais como Tate Modern, de

\footnotetext{
${ }^{18}$ https://brasil.elpais.com/brasil/2017/09/11/politica/1505164425_555164.html
} 
Londres, no Museu Guggenheim, em Nova York, e na Fundação La Caixa, em Barcelona.

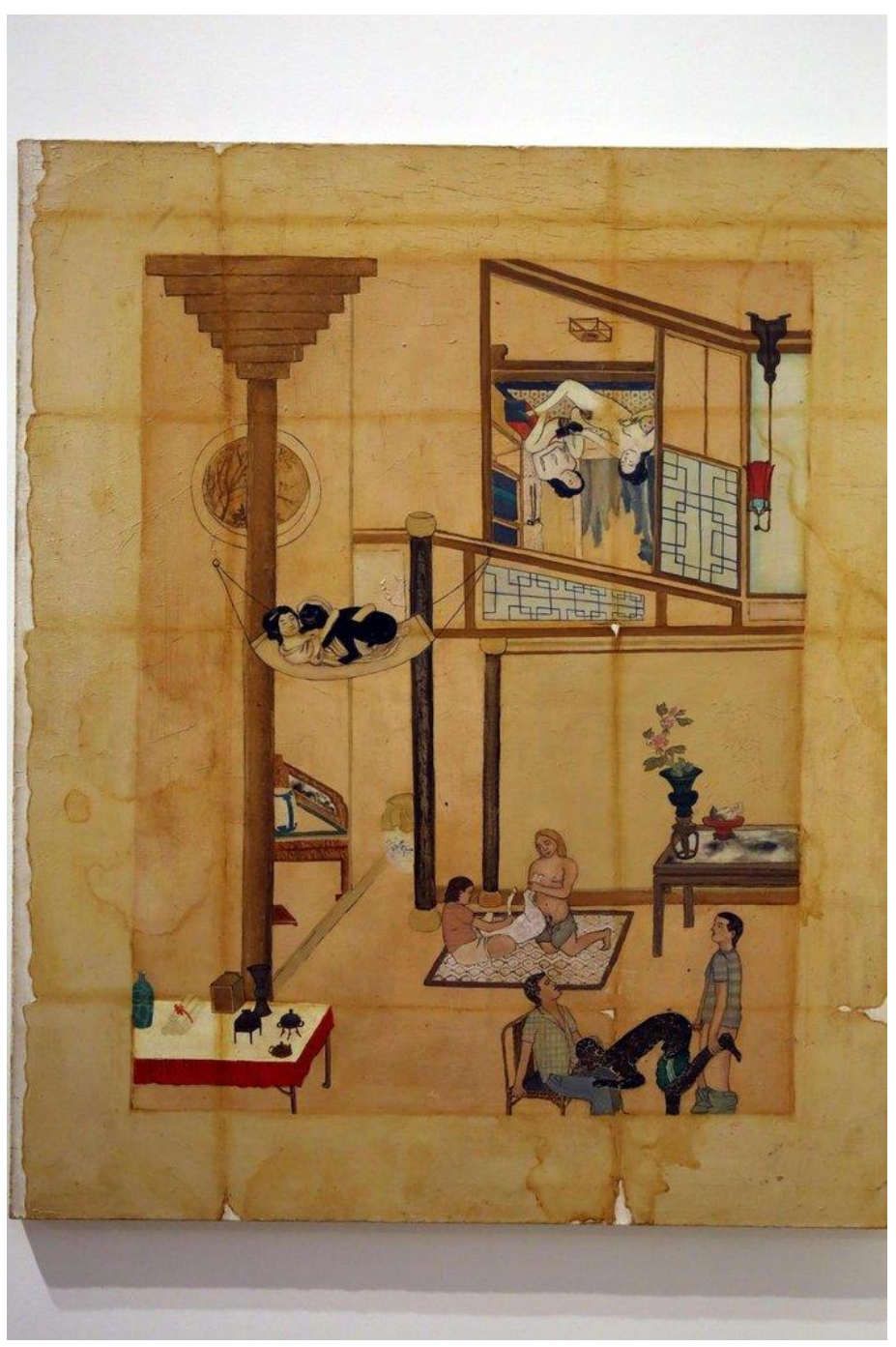

Figura 5 - Obra "Cenas do Interior II", de Adriana Varejão, 1994.

Não é a primeira vez que obras causam furor na audiência mais conservadora e são censuradas institucionalmente. Em 2006, o Centro Cultural Banco do Brasil (CCBB) do Rio de Janeiro retirou de uma exposição em cartaz a obra "Desenhando em Terços". De autoria da artista plástica Márcia X, o trabalho mostrava a foto de dois terços que desenhavam dois pênis e formavam, simultaneamente, uma cruz. 
Depois da censura e fechamento em Porto Alegre, a exposição seria, então, realizada no Rio de Janeiro, pelo MAR - Museu de Arte do Rio. Logo depois de anunciada, porém, foi censurada pelo então prefeito da cidade, Marcelo Crivella, bispo da Igreja Universal do Reino de Deus. A despeito do seu cargo, ele declarou, ironicamente, em um vídeo viralizado na internet, que a exposição só aconteceria "no fundo do mar". Um grupo de artistas, produtores culturais e políticos decidiu, então, desenvolver uma campanha de arrecadação de fundos para viabilizar a montagem da exposição no histórico espaço do Parque Lage.

A reabertura no Rio, quase um ano depois da censura do Santander Cultural, foi viabilizada através da mais bem sucedida campanha de financiamento coletivo do país, lançada em 31 de janeiro de 2018, e coordenada pelo diretor da Escola de Artes Visuais do Parque Lage, Fábio Szwarcwald. Em 58 dias, foram arrecadados um total de $\mathrm{R} \$ 1$ 1.081.156. A campanha contou com iniciativas históricas que impulsionaram o movimento, como um show de Caetano Veloso contra a censura (em 15 de março de 2018) e o Levante Queremos Queer, evento que atraiu mais de 2 mil pessoas ao parque num único sábado, em fevereiro do mesmo ano.

Além do prefeito Marcelo Crivella, outro líder político e evangélico se manifestou publicamente crítico à exposição Queermuseu. A Associação Vitória em Cristo (AVEC), entidade religiosa presidida pelo pastor Silas Malafaia ${ }^{19}$, protocolou no Ministério Público (MP), em agosto de 2018, uma representação para que a exposição, que ainda nem estava aberta ao público na Escola de Artes Visuais do Parque Lage (EAV), tivesse a classificação indicativa de 18 anos. Na representação encaminhada por Malafaia, foram anexadas imagens das obras de Adriana Varejão, Bia Leite e Fernando Baril. "Se o adulto quiser ver safadeza, o problema é dele.

\footnotetext{
${ }^{19}$ Silas Lima Malafaia (Rio de Janeiro, 14 de setembro de 1958) é um pastor protestante neopentecostal brasileiro líder da Assembleia de Deus Vitória em Cristo. Malafaia também é televangelista, graduado em psicologia, presidente da editora Central Gospel, além de ser vicepresidente do Conselho Interdenominacional de Ministros Evangélicos do Brasil (CIMEB), entidade que agrega cerca de oito mil pastores de quase todas as denominações evangélicas brasileiras. Malafaia é bastante conhecido por sua atuação política e pelo discurso de ódio sobre temas como direitos dos homossexuais e direito ao aborto, bem como por defender a chamada Teologia da Prosperidade. Em janeiro de 2013, a revista Forbes o classificou como o terceiro pastor mais rico do Brasil, com um patrimônio estimado pela publicação em 150 milhões de dólares.
} 
Mas as crianças têm que ser protegidas", disse o pastor, presidente da vertente neopentecostal da Assembleia de Deus, ao jornal O Globo ${ }^{20}$.

É importante contextualizar que a polêmica em torno da exposição Queermuseu se dá no bojo das campanhas políticas para as eleições de 2018. Esse período está marcado na história do Brasil como o acirramento de uma polarização política que estava em curso, com episódios emblemáticos como o golpe parlamentar sofrido pela presidente Dilma Roussef, em 2016; e a prisão do expresidente Luís Inácio Lula da Silva, em 2018. A prisão de Lula, às vésperas da campanha oficial eleitoral, líder das pesquisas na época, configurou um cenário favorável à eleição de Jair Messias Bolsonaro. Em tempo, Bolsonaro, candidato apoiado pela ampla maioria do eleitorado conservador (incluindo substancial apoio das igrejas evangélicas) no país, era o candidato apoiado pelos pastores Silas Malafaia e Marcelo Crivella.

Segundo o release oficial ${ }^{21}$ da exposição, o Queermuseu se propunha a ser um museu provisório, de perfil metafórico, cujo objetivo seria propiciar um campo de investigação sobre o caráter patriarcal e heteronormativo do museu como instituição. Segundo o curador da mostra, Gaudêncio Fidelis, "é uma exposição fundada na democracia e na visão de um processo de inclusão". O projeto inclusivo do Queermuseu se localizava frontalmente contrário à emergente onda conservadora no Brasil que culminou com a eleição do atual presidente. No centro do discurso político bolsonarista está o projeto moralizante e fundamentalista cristão sobre pautas identitárias, candentes no mundo todo desde o início do século XXI.

É sintomático - e pertinente à abordagem desse capítulo - que muitas das matérias publicadas acerca do episódio de censura com o projeto Queermuseu circularam na mídia com títulos que exploravam o aspecto representacional das obras polêmicas que compunham a exposição coletiva. O jornal gaúcho Zero Hora publicou um texto ${ }^{22}$ do jornalista Nathan Fernandes, sob a manchete "O que representam as obras que causaram o fim da exposição Queermuseu". Fernando Baril, autor da obra que trazia a imagem subversiva de Jesus Shiva, em resposta à Fernandes, retoma as questões sobre representação na arte:

\footnotetext{
${ }^{20}$ https://oglobo.globo.com/cultura/artes-visuais/pastor-pede-ao-mp-que-queermuseu-tenhaclassificacao-indicativa-de-18-anos-22963346

${ }^{21}$ http://eavparquelage.rj.gov.br/wp-content/uploads/2018/02/EAV_release_Queermuseu_bilingue.pdf

22 https://revistagalileu.globo.com/Cultura/noticia/2017/09/o-que-representam-obras-que-causaram-ofim-da-exposicao-queermuseu.html
} 
"Era uma semana santa, e eu estava lendo sobre as santas indianas, então resolvi fazer uma cruza entre Jesus Cristo e a deusa Shiva. Deu aquele montaréu de braços carregando só as porcarias que o Ocidente e a Igreja nos oferecem. Certa vez, Matisse fez uma exposição em Paris e, na mostra, tinha uma pintura de uma mulher completamente verde. Uma dama da sociedade parisiense disse 'desculpe, senhor Matisse, mas nunca vi uma mulher verde', ao que Matisse respondeu que aquilo não era uma mulher verde, mas uma pintura. Aquilo não é Jesus, é uma pintura. É a minha cabeça, ponto. Me sinto bem à vontade para pintar o que quiser." (BARIL, 2017)

O caso da polêmica recepção da exposição Queermuseu: cartografias da diferença na arte brasileira ilustra de forma emblemática- considerando a amplitude dos desdobramentos desse episódio - como setores conservadores da sociedade brasileira têm reagido às imagens dessagradas produzidas no âmbito das artes. Influentes líderes pentecostais e neopentecostais, sob ímpetos fundamentalistas, oportunismos e interesses de poder, se associam a essa agenda de modo a garantir a manutenção e ampliação de um projeto moralizante que se ancora na demanda da conversão, em detrimento ao convívio com as diferenças. Como resposta a esse Jesus Cristo excludente e hegemônico, surgem no âmbito das artes visuais no Brasil outras narrativas que disputam a imagem de um Cristo dissidente.

\subsection{Ventura Profana: abundante vida}

Ventura Profana é uma jovem artista brasileira emergente, travesti, preta e periférica, que utiliza diversos suportes artísticos e midiáticos para produzir seus trabalhos. Através deles, ela busca ressignificar símbolos e códigos pentecostais. Com isso, a artista baiana rompe com a narrativa cristã hegemônica, reivindicando Jesus Cristo como uma figura dissidente e não-normativa e afirmando a si mesma como um corpo apocalíptico. Artista visual, missionária, compositora, cantora evangelista, escritora e performer, Ventura problematiza os efeitos sociais, culturais e políticos dos processos de tradução e interpretação de textos bíblicos, historicamente apropriados por projetos políticos de embranquecimento populacional e concentração de poder. Com seu trabalho anticolonial, a artista 
refuta a condenação mórbida dada aos corpos marginalizados pelos processos colonizadores, reivindicando pra si e para seus pares dissidentes a vida abundante prometida aos cristãos ${ }^{23}$.

Pela amplitude de sua pesquisa artística sobre os repertórios pentecostais e pela pertinência de seu discurso radicalmente contemporâneo justapondo vivência e produção artística, Ventura Profana aparece nesse estudo como fio condutor e conector com as abordagens de outros artistas contemporâneos brasileiros sobre o tema da presença evangélica no país e sua articulação com outros campos de pesquisa sobre os temas do sagrado, da transgressão e da representação no âmbito da arte. Oportunamente, trataremos de tópicos emergentes da contemporaneidade, como as discussões interseccionais de gênero, sexualidade e raça, conduzindo as elaborações até as prementes abordagens dos estudos póscoloniais.

Para conduzir a investigação sobre o trabalho de Ventura Profana, citarei ao longo deste estudo trechos de uma conversa que tive presencialmente com a artista em 2019, durante um encontro em um café na Lapa, Rio de Janeiro. A transcrição desse diálogo estará na íntegra, como anexo, no final dessa dissertação. Somam-se a essas citações trechos de outras entrevistas que Ventura deu para diversos veículos de comunicação nos últimos três anos. Considero as explanações de Ventura Profana um material imprescindível para essa pesquisa, não apenas para nos situarmos sobre o contexto e as motivações das representações do sagrado propostas pela artista, mas, especialmente, porque suas falas são prodigiosas no sentido de articular as tantas camadas de significados deste tema tão complexo e em constante movimento.

Esse esforço articulador, comunicativo e contra-hegemônico de Ventura está também no centro do desejo dessa dissertação, de modo que, muitas vezes, as palavras da artista são mais pertinentes e assertivas a esse objetivo do que todo meu exercício científico-acadêmico. Nesse sentido, recorro, com frequência, às próprias elaborações de Ventura como quem quer produzir um estudo não apenas a partir da obra da artista, mas, sobretudo, em diálogo com suas ideias.

Nascida em Salvador em 1993, e criada na pequena cidade de Catu, localizada a aproximadamente oitenta quilômetros da capital baiana, Ventura

\footnotetext{
${ }^{23} \mathrm{Na}$ Bíblia, no livro de João, no capítulo 10 e versículo 10, Jesus Cristo diz: “(...) eu vim para que tenham vida; e a tenham em abundância."
} 
Profana chegou ao Rio de Janeiro aos doze anos de idade, junto a sua família. Sua bisavó, em meados da década de 30, deixa o terreiro de candomblé na Bahia e se converte à igreja batista, a partir de um trabalho de conversão feito por um missionário norte-americano. Com apenas alguns dias de vida, Ventura foi apresentada $^{24}$ na Primeira Igreja Batista de Catu. Foi nessa mesma igreja que, ainda na infância, começa a desenvolver suas aptidões artísticas, participando de montagens teatrais.

Ao se mudar para o bairro suburbano carioca de Olaria, começou a frequentar a Igreja Cristã de Nova Vida ${ }^{25}$. Na nova igreja, Ventura começa a participar de alguns ministérios dentro da congregação, como os grupos de evangelismo, dança e louvor. Aos 16 anos, ingressa em uma Escola Livre de Artes. Essa experiência foi marcante na relação entre a artista e a religião. Abandona então a igreja aos 18 e "dois anos depois eu começo a tecer um trabalho pensando no meu corpo, na beleza do meu corpo, da dissidência, da monstruosidade, me reconhecendo como um corpo trans, um corpo monstro", afirma Ventura em nossa conversa ${ }^{26}$.

O conceito da monstruosidade, articulado por Ventura Profana para tratar das motivações iniciais em torno da representação artística do seu corpo negro e travesti, nos serve como localização do discurso e prática dialética da artista. $O$ monstro como "forma extrema de alteridade, [...] é sempre definido a partir de uma comunidade de não-monstros" (NAZÁRIO, 1998, p. 29). A monstruosidade é então “[...] o outro, o estranho, o estrangeiro, o 'inimigo natural' pronto a encarnar o Mal e contaminar, com sua simples presença, a humanidade [...]" (NAZÁRIO, 1998, p. 285). Essa sua marcação de "diferença", faz do monstro um risco para quem ultrapassar fronteiras.

\footnotetext{
${ }^{24}$ Diz-se "apresentar recém-nascido" no contexto pentecostal para o ritual em que as famílias levam os bebês com seus primeiros dias para participarem do culto e, então, serem apresentados, simbolicamente, à Jesus Cristo, e também à comunidade.

${ }^{25}$ A Aliança das Igrejas Cristãs Nova Vida (AICNV), também conhecida simplesmente como Igreja
Cristã Nova Vida (ICNV) é uma denominação protestante, de orientação pentecostal reformada. Foi
fundada em 1960 pelo bispo Robert McAlister, depois de iniciar transmissão de programas de rádio. É
chefiada pelo seu bispo primaz Walter McAlister. O primeiro nome da denominação foi Igreja
Pentecostal de Nova Vida, mas em 2008 foi decidido pelo colégio de bispos que passaria a se
chamar lgreja Cristã Nova Vida, devido à nova orientação pentecostal reformada e para evitar
associações com o Neopentecostalismo, rejeitado pela denominação.

${ }^{26}$ A partir desse trecho, toda vez que for mencionada a fala de Ventura Profana registrada em nossa conversa em 2019, adotarei como padrão a citação sem referência bibliográfica. Nas vezes em que a fala destacada de Ventura estiver contextualizada em alguma publicação ou site, a citação será acompanhada da referência.
} 
Assim, o monstro é uma construção cultural que serve às normatividades de gênero e sexualidade, sobre as quais Ventura se relacionada de forma monstruosamente insubmissa; mas também é uma circunscrição sociocultural na qual segmentos da sociedade se tornam impermeáveis, ou repelentes à diferença. Na obra de Ventura Profana, portanto, o monstro também é a relação melindrosa entre população evangélica e o universo secular. Se pensarmos na súbita aversão que os setores da classe média progressista e a elite intelectual adquiriu aos símbolos evangélicos, podemos pensar que o "monstro evangélico" foi criado alheio aos olhos cuidadosos do tradicionalismo cultural brasileiro. Ventura, como corpo dissidente e pastora pentecostal, é, portanto, um agenciamento de monstruosidades. Segundo Jeffrey Cohen, autor da Teoria Monstro, o monstro

[...] existe para demarcar os laços que mantêm unido aquele sistema de relações que chamamos cultura, para chamar atenção - uma horrível atenção - a fronteiras que não podem - não devem - ser cruzadas. [...] Como uma espécie de pastor, [...] delimita o espaço social através do qual os corpos culturais podem se movimentar [...]. (COHEN, 2000, p. 42-43, grifo do autor)

Em 2016, a artista lança o livro $A$ cor de catu². A publicação é o primeiro projeto que apresenta sua assinatura como Ventura Profana. Não é ainda dessa vez, porém, que será atribuído este crédito à autoria da obra. O nome que aparece como autor do livro é de Jackson Boaventura. Apenas as ilustrações e diagramação receberam a assinatura que seria adotada pela artista nos trabalhos posteriores. $A$ cor de catu é um livro de memórias, onde Ventura compartilha uma coletânea de escritos (em prosa e poesia), ilustrados por desenhos, pinturas e colagens, sobre sua infância na interiorana cidade de Catu. Um projeto de montagem de reminiscências em meio a uma transição ainda fragmentada.

eu sou este livro, uma revisitação, minha sombra na
madrugada
meus fantasmas e fantasias "confrontal"
tentativa de concerto das músicas não compostas

${ }^{27}$ https://issuu.com/porventura/docs/acordecatuimpresso 1e0636c3d9d31a 
dos erros que me construíram, parindo meus e outros Jacksons, que se atravessam a reparação dos meus anos, vômitos de todas as náuseas homem nu interior, brilhante. folclore e concreto batom e cristo reescrito (BOAVENTURA, 2016, p. 3)

Ainda em 2016, Ventura Profana começa a desenvolver sua pesquisa que propõe novas abordagens sobre um ambiente que the é muito familiar, literalmente: os símbolos pentecostais. As memórias reaparecem, mas desta vez, a partir de um desejo de ruptura com um ciclo de opressão e violência vivenciado pela artista dentro do contexto religioso. O processo de rompimento se desenvolve de forma propositiva. Ventura começa então a disputar a narrativa cristã, propondo um Jesus Cristo não-normativo, acolhedor e que se associa aos corpos dissidentes. Sobre esse processo, Ventura diz:

\footnotetext{
"Então, eu acho que a igreja e a minha trajetória cristã foi inteira violenta, foi inteira agressiva, ela me castrou em diversas instâncias, e, à medida que eu almejava um lugar de liberdade - inclusive liberdade de criação -, eu precisei investigar e precisei me reconectar com essa herança, essa memória cristã evangélica, na minha vida."
}

As primeiras experiências performáticas de Ventura Profana se desdobram da obra Universal é o reino das bichas, em 2017. O trabalho consiste em um objeto artístico constituído por uma calcinha de malha branca, estampada com a logomarca da Igreja Universal do Reino de Deus. Ventura propõe com a obra uma abordagem subversiva do emblema da popularíssima igreja, que se consolidou como principal expoente do crescimento neopentecostal no Brasil. Com esse trabalho, a artista delineia alguns aspectos centrais que se firmarão em sua trajetória artística: o posicionamento afirmativo da artista como missionária-travesti, se apresentando como uma evangelizadora com hábil domínio da oratória pentecostal; e a estratégia discursiva de criação de novos repertórios de leituras da iconografia (neo)pentecostal. 


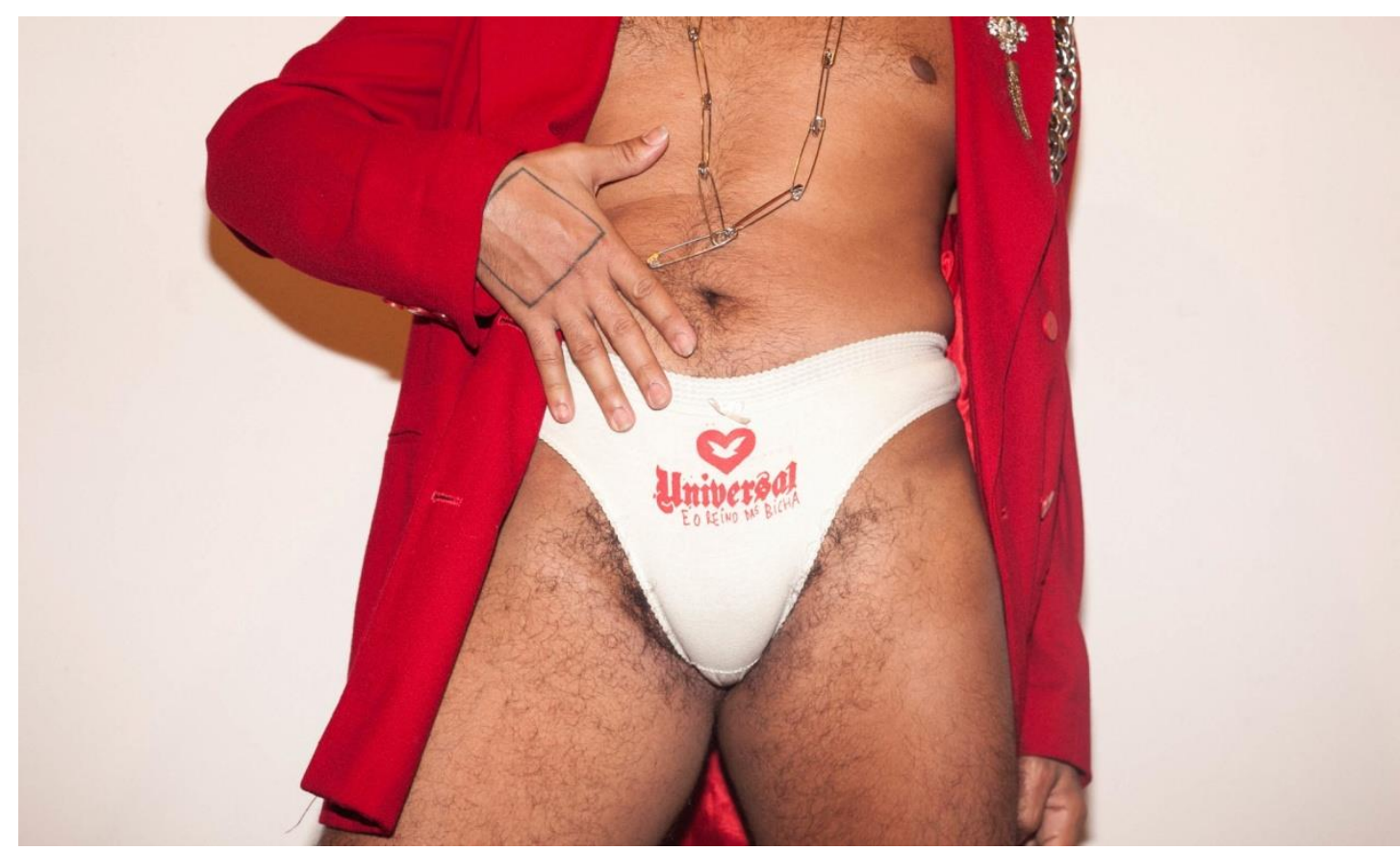

Figura 6 - Obra "Universal é o reino das bichas", de Ventura Profana, 2017. Foto: Jhonatta Vicente

A pomba branca sobre o coração vermelho que ilustram a logomarca da IURD (comumente acompanhada da inscrição positiva "pare de sofrer"), na obra Universal é o reino das bichas, voa livre sobre o gozo pleno das sexualidades dissidentes. É importante ressaltar que "bicha", no discurso de Ventura Profana, não diz respeito apenas à sexualidade dos corpos, mas também se relaciona performaticamente contra a lógica binária de gênero, propondo uma crítica à cisheteronormatividade.

O trabalho Universal é o reino das bichas (e, de maneira geral, a obra de Ventura Profana) traz em seu centro discursivo um tático jogo de linguagem no qual a artista, ao propor a ressignificação dos símbolos pentecostais, evoca a possibilidade de outras narrativas e subjetividades evangélicas. A disputa contra a narrativa hegemônica sobre a fé cristã - propondo outras leituras até da própria figura de Jesus Cristo -, na obra de Ventura, passa invariavelmente pela profanação dos sentidos hegemônicos contidos nas representações evangélicas. Ou melhor, a pesquisa artística de Ventura Profana tem se dedicado em não desconsiderar a potência comunicativa do universo pentecostal. Ao contrário disso, a artista opera novas abordagens desse repertório para criar uma nova agenda discursiva. É o que 
o sociólogo Stuart Hall, expoente nome dos estudos culturais contemporâneos, chama de "luta discursiva" e seus desdobramentos na "política cultural" contemporânea.

Daí porque não deve nos surpreender que "as lutas pelo poder sejam, crescentemente, simbólicas e discursivas, ao invés de tomar, simplesmente uma forma física e compulsiva, e que as próprias políticas assumam progressivamente a feição de uma 'política cultural'". (HALL, 1997, p. 20)

Abrimos aqui um espaço para situar a abordagem do trabalho artístico de Ventura Profana sobre os símbolos evangélicos no contexto dos estudos contemporâneos sobre representação.

De maneira geral, existem três abordagens teóricas no âmbito dos estudos sobre representação. $\mathrm{Na}$ abordagem reflexiva, a linguagem apenas reflete o que já existe no mundo - seus objetos, pessoas, acontecimentos - tal como um espelho, sem interferir no processo de representação. $\mathrm{Na}$ abordagem intencional, a linguagem expressa as particularidades (idiossincrasias) do pensamento do emissor, aquilo que ele quer dizer, os traços de sua personalidade. $\mathrm{Na}$ abordagem construcionista, a mais usada por Hall (2000), o significado é construído através da linguagem, com o uso de sistemas representacionais, constituído por conceitos e signos. Nessa abordagem, são os atores sociais que utilizam os sistemas conceituais de sua cultura e outros sistemas linguísticos e representacionais para construir significado, para tornar o mundo significativo e comunicar de forma coerente este mundo para outros (Hall, 2000, p.25). Kathleen Woodward, especialista nos estudos de concepções teóricas contemporâneas sobre identidades sociais, afirma:

A representação inclui as práticas de significação e os sistemas simbólicos, posicionando-nos como sujeito. É por meio dos significados produzidos pelas representações que damos sentido à nossa experiência e aquilo que somos (WOODWARD, 2004, p.17). 
Em um processo no qual o sistema de representação dá-se através da linguagem, nossos conceitos compartilhados necessitam ser expressos em uma linguagem comum, em palavras escritas, sons falados e imagens visuais que possam ser decodificadas pelos grupos aos quais se dirigem as mensagens. É preciso lançar mão de um repertório de códigos culturais para que a mensagem possa estar, de fato, carregada de significados. Os signos - palavras, sons e imagens carregados de sentidos - representam os conceitos assimilados por nossa mente e a sua relação com o mundo exterior, traduzindo o sistema de significação de cada cultura e ligando-se a formas de poder. Assim, através dos sistemas de representação, constroem-se lugares a partir de onde os indivíduos podem se posicionar e falar. Ainda em Woodward. "Todas as práticas de significação que produzem significados envolvem relações de poder, incluindo o poder para definir quem é incluído e quem é excluído (2004, p18)".

Há, portanto, na obra de Ventura Profana, uma marca inconteste e estratégica de disputa de poder contra a ideia instituída do que é "ser evangélico" no Brasil, e, dessa forma, questiona também sobre quem tem direito de se relacionar com o sagrado cristão. Nesse litígio religioso, Ventura congrega simbolicamente todos os corpos "demonizados" pela arcaica moral cristã, fundando um novo evangelho, firmado na inclusão dos sujeitos historicamente oprimidos e de suas subjetividades insubmissas. Mais adiante, trataremos da associação da obra de Ventura Profana com os discursos pós-coloniais de reivindicação e de reposicionamento de fala e escuta dos corpos subalternizados.

\subsection{O reino é das bichas}

A calcinha com a inscrição "Universal é o reino das bichas" faz parte da indumentária que compõe a performance $O$ reino é das bichas, realizada pela primeira vez em 2017, no espaço cultural independente Despina, localizado no Centro do Rio de Janeiro. O registro da performance ${ }^{28}$ está disponível na plataforma YouTube através de uma vídeo arte produzida por Gabriel Massan. Com uma roupa vermelha que cobria praticamente todo o corpo e uma máscara no estilo "riot", estilizada com uma coroa de espinhos produzida com alfinetes, Ventura Profana

\footnotetext{
${ }^{28} \mathrm{https}: / /$ www.youtube.com/watch?v=aa5EkHqHzUY
} 
enunciava palavras proféticas de abundante vida sobre base musical eletrônica. $A$ performance marca o início de uma parceria profícua da artista com o produtor Jhonatta Vicente, que assina como nome artístico PODESERDESLIGADO. "Eu não vou morrer!" brada Ventura repetidas vezes na obra performática que tem uma duração aproximada de 40 minutos. Segundo a sinopse do trabalho, divulgada pelo portal Segunda Preta ${ }^{29}$ :

O Reino é das bichas é uma sátira religiosa em encontro aos fundamentos das bichas. A profanação se dirigiu ao projeto de moralização do poder político que se instaurava no Rio de Janeiro com a eleição do atual prefeito Marcelo Crivella, também Bispo da instituição religiosa Igreja Universal do Reino de Deus. Contudo, a potência performática não se enclausura nas paredes institucionais. "Eu não vou morrer" canta Ventura Profana em culto à Deusa Travestí. O trabalho é antes de qualquer coisa, um clamor por socorro, justiça e restituição. Parem de nos matar!!! Ventura Profana e Jhonatta Vicente resgatam vestígios de uma educação evangélica, criando um paralelo entre o genocídio à TLGBs ${ }^{30}$ e a crucificação de Cristo.

Com a performance $O$ reino é das bichas, Ventura se posiciona frontalmente contra os projetos de poder evangélicos, que foram se constituindo a partir da década de 1970, liderados por pastores populistas e empreendedores da fé, que hoje têm estruturados verdadeiros impérios políticos, midiáticos e empresariais no Brasil. A Igreja Universal do Reino de Deus (IURD), personificada simbolicamente na figura do seu fundador, o Bispo Edir Macedo, é um emblema da abrangência e da capilarização do projeto de poder neopentecostal no país. A obra O reino é das bichas, conforme descrito na sinopse do trabalho, marca o momento histórico em que um dos líderes mais populares da IURD, o bispo Marcelo Crivella, sobrinho de Edir, chegava ao poder no posto mais alto do sistema executivo da cidade do Rio de Janeiro, se tornando prefeito da segunda maior cidade do país, com forte apoio das igrejas evangélicas. Um episódio cheio de significados sobre a escalada da participação e influência evangélica na política institucional do Brasil e de constatação da amplitude e força de atuação da IURD em diversos segmentos da

\footnotetext{
${ }^{29} \mathrm{http}: / /$ segundapreta.com/o-reino-e-das-bichas/

${ }^{30}$ Ventura Profana frequentemente subverte a sigla LGBTQIA+ (Lésbicas, Gays, Bissexuais e Transexuais/Travestis, Queers, Interssexuais, Assexuais) destacando a transexualidade.e a travestilidade, que são, afinal, a população mais violentada segundo dados oficiais.
} 
sociedade carioca e brasileira (embora adiante tivéssemos comprovações mais explícitas e dramáticas desse sucesso).

Segundo estimativas do Censo de 2010 realizado pelo Instituto Brasileiro de Geografia e Estatística (IBGE), a Igreja Universal do Reino de Deus tem mais de seis mil templos, doze mil pastores e um milhão e oitocentos mil fiéis ao redor do país. Pelas estimativas próprias da IURD, são cerca de oito milhões de seguidores e quinze mil pastores espalhados em cento e cinco países. A enorme abrangência da Universal tem sido conquistada a partir de fortes investimentos em projetos missionários e na administração de empresas de comunicação no Brasil e outros países do mundo. A rápida popularidade da IURD se deu, especialmente, pela propagação do discurso teológico da Teologia da Prosperidade, doutrina religiosa cristã que defende que a bênção financeira é desígnio de Deus para os fiéis e que a fé, o discurso positivo e as doações para os ministérios irão contribuir para a riqueza material do crente doador.

Como vimos em capítulos anteriores, este argumento de causa e relação entre o acúmulo de capital e a prosperidade é base teórica da análise do livro $A$ ética protestante e o espírito do capitalismo, de Max Weber, lançado em 1904-1905. De acordo com Weber, estamos diante de uma visão abrangente da ética do trabalho, na lógica de produção do capital. A tese do sociólogo alemão sobre a relação estruturante do protestantismo com o desenvolvimento global do capitalismo é ainda um dos suportes teóricos mais recorridos para tratar da ascensão evangélica no mundo. No entanto, a visão generalista e eurocentrada de Weber sobre esse fenômeno não se sustenta intacta diante das muitas nuances e particularidades que o evento do crescimento pentecostal foi adquirindo a partir da última metade do século XX mundo afora. Um dos aspectos mais pertinentes para esta pesquisa em relação à propagação global - e especialmente brasileira - da Teologia da Prosperidade é a transformação de uma cultura religiosa moderna em produto industrial via comunicação de massa.

Nos EUA, a partir da década de 1960, a disputa pela audiência da mídia televisiva acirrou-se entre as igrejas evangélicas e pentecostais. Assim, a expansão da Teologia da Prosperidade manteve forte relação com o televangelismo norteamericano. "foi o televangelista Oral Roberts quem criou a noção de "Vida Abundante", e deu início à doutrina da prosperidade, prometendo retorno financeiro sete vezes maior do que o valor ofertado" (MARIANO, 1999, p. 152). Toda essa 
sofisticação de formulação e aprimoramento dos meios de disseminação da Teologia da Prosperidade confere uma nova fórmula de exercício e promoção da fé. As atividades religiosas passam a contar com um conjunto de procedimentos altamente comprometido com o desenvolvimento da sociedade de consumo. Nesse sentido, os veículos de comunicação em massa tornam-se ferramentas estratégicas para atingir o maior contingente possível de seguidores (e potenciais fiéis). Há, portanto, uma relação intrínseca da propagação da Teologia da Prosperidade no âmbito das igrejas (neo)pentecostais e a apropriação desses grupos às ferramentas de comunicação em massa e inclusão pelo consumo.

O pioneirismo americano, desenvolvido no rádio, logo propiciou a expansão midiática religiosa também pela televisão, cujo potencial de alcance é exponencial, visto seu caráter de comunicação massiva. Não demorou muito para isto chegar ao Brasil, tendo início na década de 1990. Conforme afirma Lima (2005), a referida tendência foi simbolizada pela compra da TV Record pela Igreja Universal do Reino de Deus, bem como a entrada em funcionamento da Rede Vida de Televisão, ligada à Igreja Católica, em 1995.

O maior avanço é o das igrejas evangélicas neopentecostais, embora, historicamente, a Igreja Católica seja o maior concessionário de emissoras de rádio no Brasil. Em alguns casos, a presença das igrejas como concessionárias é bastante evidente, como, por exemplo, na programação vespertina dos canais da TV aberta, tanto em VHF como em UHF. (LIMA, 2011, p. 30)

Assim, a "espetacularização" da fé, feita em escala industrial pelos programas televangelísticos da IURD, está alicerçada sobre uma lógica de consumo, na qual os fiéis internalizam modelos sociais a serem seguidos. Desse modo, verifica-se uma associação entre a fé "iurdana" e o espírito consumista, no qual as pessoas convertidas creem que a conquista de bens materiais aliadas a ascensão social evidencia a intervenção divina em suas vidas. Isso mostra "como as camadas populares convertidas ao pentecostalismo veem representados seus desejos de participar do processo simbólico que reafirma os poderes de uma sociedade que reifica a cultura do consumo" (NASCIMENTO, 2012, p. 73).

O termo "comunicação" deriva do verbo comunicare que em latim significa "compartilhar, tornar comum", implicando sempre em participação, estabelecimento 
de relações, agenciamento de uma multiplicidade de sentidos. A comunicação de massa tem caráter abrangente e cosmopolita, dirige-se a um público indiscriminado e heterogêneo, é sustentada pela economia de mercado e gerida por organizações complexas com ampla divisão e especialização do trabalho, fruto das sociedades industriais modernas. A difusão e o consumo dos bens simbólicos, acionados pelos meios de comunicação de massa, geram a "cultura de massa" ou a "cultura para as massas", como apontam os intelectuais da Escola de Frankfurt. Adorno e Horkheimer, por exemplo, problematizaram o termo "cultura de massa" propondo como alternativa o conceito de indústria cultural; uma vez que, o uso indiscriminado da expressão cultura de massa poderia sugerir um entendimento vago desse "tipo de cultura" como uma nova forma genuína de arte popular, ou seja, uma cultura surgida espontaneamente do interior das massas.

A crítica ao termo e conceito "cultura para as massas" foi chamada de apocalíptica pelo semiólogo italiano Umberto Eco em seu livro Apocalípticos e Integrados (1965). O título demarcava a divisão de autores entre os termos. Para os integrados, a revelação e a transmissão das significações do mundo, comum a toda produção cultural, exercem na indústria cultural a mesma função valorativa, com mais velocidade e maior difusão (alcance das massas), devido ao desenvolvimento da tecnologia dos meios de comunicação na contemporaneidade. $O$ que configuraria a indústria cultural como um meio possível e eficaz de combate à alienação, por ser o principal meio democratizador da informação. (BOSI, 1994, p. 321).

Para os apocalípticos, que partem da apreciação negativa da indústria cultural formalizada pela Escola de Frankfurt, a indústria cultural exerce um poder alienante, constituindo-se como a base do totalitarismo moderno, no qual o indivíduo é levado a não refletir sobre sua condição histórica e o meio ao qual está inserido.

Frankstein, um Frankstein tecnológico nos ameaça. [...] Passamos a viver num mundo de máquinas de transportar, de fabricar, de pensar, Frankstein, nosso duplo, aquele que criamos, assume sua autonomia e em seguida o poder. Evidência intuitiva imediatamente compensada por outra crença: graças à comunicação, podemos agora estabelecer um melhor contato com as nações, os grupo, os indivíduos, até com nós mesmos, já que as máquinas de pensar nos esclarecem acerca do nosso próprio espírito. 
Duas crenças em oposição, dois antagonismos que se nutrem um do outro. (SFEZ, 1994, p. 19).

$\mathrm{Na}$ Crítica da Comunicação, Lucien Sfez desenvolve a análise da comunicação entendendo-a no campo da "tecnocomunicação". Para o autor, as tecnologias da comunicação impõem-se como "uma nova teologia", ocupando a grande lacuna aberta pela laicização do Estado, da história, de Deus, ou seja, dos elementos estruturantes da civilização ocidental. A ausência de referências, as fragmentações e as segmentações ocasionadas pela tecnologia, além da crise de valores na contemporaneidade, fazem da comunicação a "(...) Voz única; só ela pode unificar um universo que perdeu no trajeto qualquer outro referente." (SFEZ, 1997, p. 21)

É no contexto super moderno dos aparatos digitais que a comunicação em massa se desenvolve nos dias de hoje. A televangelização, embora ainda atuante, disputa em desiguais condições a atenção de potenciais fiéis, agora conectados em tempo integral pelas telas dos smartphones, tablets e notebooks. As rádios evangélicas perderam sua influência para as plataformas de streaming e as pregações hoje são vistas aos milhões pelo YouTube. A relação entre fé e tecnologia tem mudado substancialmente a forma como evangélicos tem se relacionado com a palavra bíblica, com as manifestações religiosas e com os produtos gospel, especialmente nesse momento pandêmico, no qual toda a população mundial se vê restrita de mobilidade - e ainda mais apegada aos ambientes virtuais. É nesse novo templo da imagem e da palavra, a internet, que Ventura Profana investe para fazer circular sua mensagem do Cristo dissidente e anticolonial.

Em abril de 2020, depois de aproximadamente um mês do decreto oficial da pandemia do novo coronavírus pela Organização Mundial da Saúde (OMS), o Instituto Moreira Salles lançou o Programa Convida, no âmbito do projeto \#IMSQuarentena. O programa comissionou mais de 170 projetos artísticos, como resposta aos danos causados pela pandemia na produção cultural do país. Os artistas convidados, muitos deles atuantes em regiões de periferia, se enquadravam em uma pauta de critérios que levava em conta, além da situação extrema de vulnerabilidade, a diversidade de identidades presentes no Brasil - de raça, gênero, 
regionalidade, contexto social e cultural. No site oficial ${ }^{31}$ do IMS, o release do programa destaca o aspecto político da seleção de artistas:

A interrogação do mundo em que vivemos, assim como das possibilidades do mundo em que queremos viver, as evidências da violência e do racismo, da exclusão social, das alterações do clima e dos ataques ao meio ambiente, os desafios da democracia na atualidade perante os ataques a que é submetida, as questões da sobrevivência e da resistência, dos direitos civis, a urgência da solidariedade e de novas possibilidades de ação política, as questões da produção artística entre os ambientes virtual e presencial e o papel da arte neste tempo em que vivemos são algumas das pautas que gostaríamos de ver abordadas. A elas, se juntarão todas as questões e os diferentes modos de fazer que os artistas manifestem em seus trabalhos.

Dentre os artistas selecionados, estava Ventura Profana, que produziu uma série de colagens digitais intitulada Sonda (2020). Parte das fotomontagens traz figuras masculinas em posição de poder, reafirmando seus pactos patriarcais, dispostos em ambientes religiosos, templos ficcionais, elementos bélicos e cenários apocalípticos. A coalisão masculina aparecia tanto no recorte da célebre pintura renascentista $A$ criação de Adão, feita pelo artista italiano Michelangelo (uma das mais emblemáticas representações androcêntricas na arte) quanto na aglomeração de políticos brancos, engravatados, ministrando cultos e orações em espaços que deveriam prezar a laicidade do Estado. Ventura em texto ${ }^{32}$ de apresentação do trabalho afirma:

vem, e vê: em sonda, revelam-se parcelas da anatomia, gestos e coreografias adotadas e divinizadas pelo inimigo: 0 homem mau, fariseu, devorador. farejo as estruturantes implicações abraâmicas na sociedade desmaiada e estudo sua lei para atordoá-la, no cumprimento da missão de transverter veneno em manancial de águas vivas. a era cristã/colonial empesteou em nossas vidasterrassaberesespíritostemposconjugações sua cruel marca condenatória racista, travestifóbica e heteronormativa.

\footnotetext{
${ }^{31}$ https://ims.com.br/2020/07/20/programa-convida-etapa-3/

${ }^{32}$ https://ims.com.br/convida/ventura-profana/
} 
ao compor os selos que vos apresento, busco evacuar a gangrena provocada pela natureza diabólica da branquitude.

Dentre as figuras políticas que estão representadas na série Sonda, o presidente Jair Bolsonaro aparece em uma das colagens através do registro no qual aparece tossindo, com a mão defronte à boca, e os olhos revirados. A fotografia de Gabriela Biló viralizou (com polissemia pertinente da expressão) no contexto que marcou a posição negacionista do chefe de Estado brasileiro diante dos trágicos números sobre a pandemia de Covid-19. Na fotomontagem de Ventura Profana, Bolsonaro aparece em frente a uma profusão de animais abatidos em frigoríficos. A composição da imagem destaca a necropolítica praticada pelo governo federal, que vem sendo apoiado por diversos setores conservadores da sociedade brasileira.

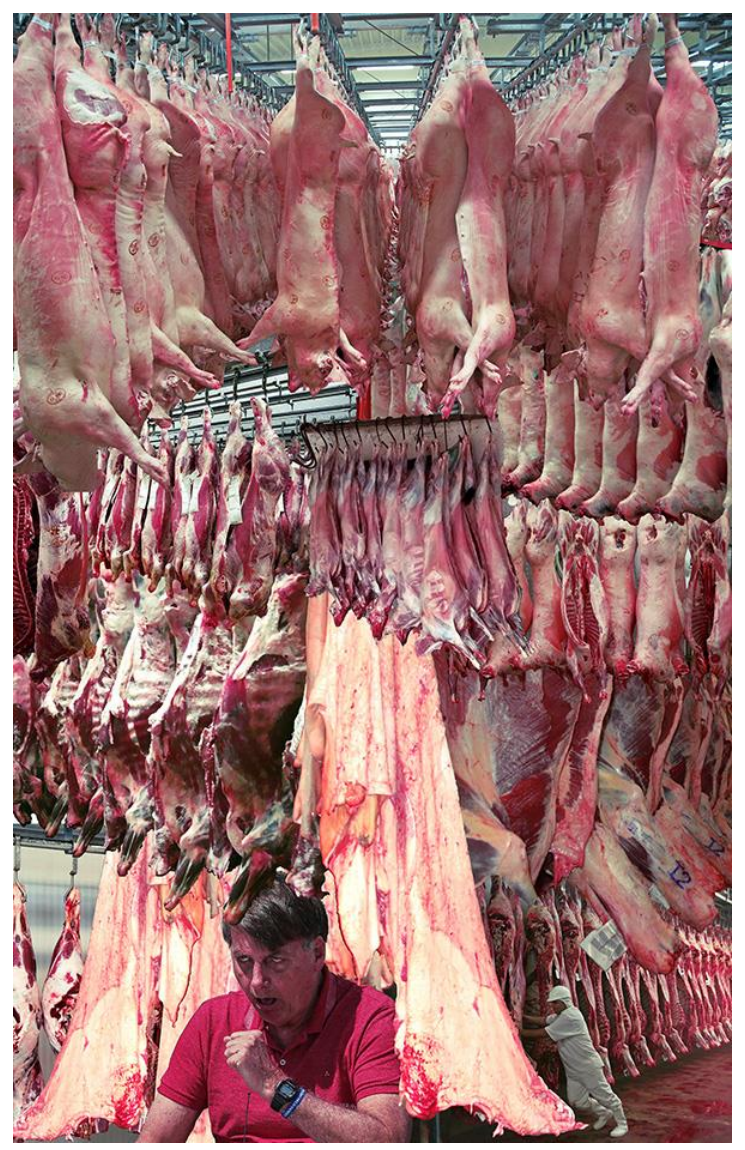

Figura 7 - Série "Sonda", de Ventura Profana, 2020. 


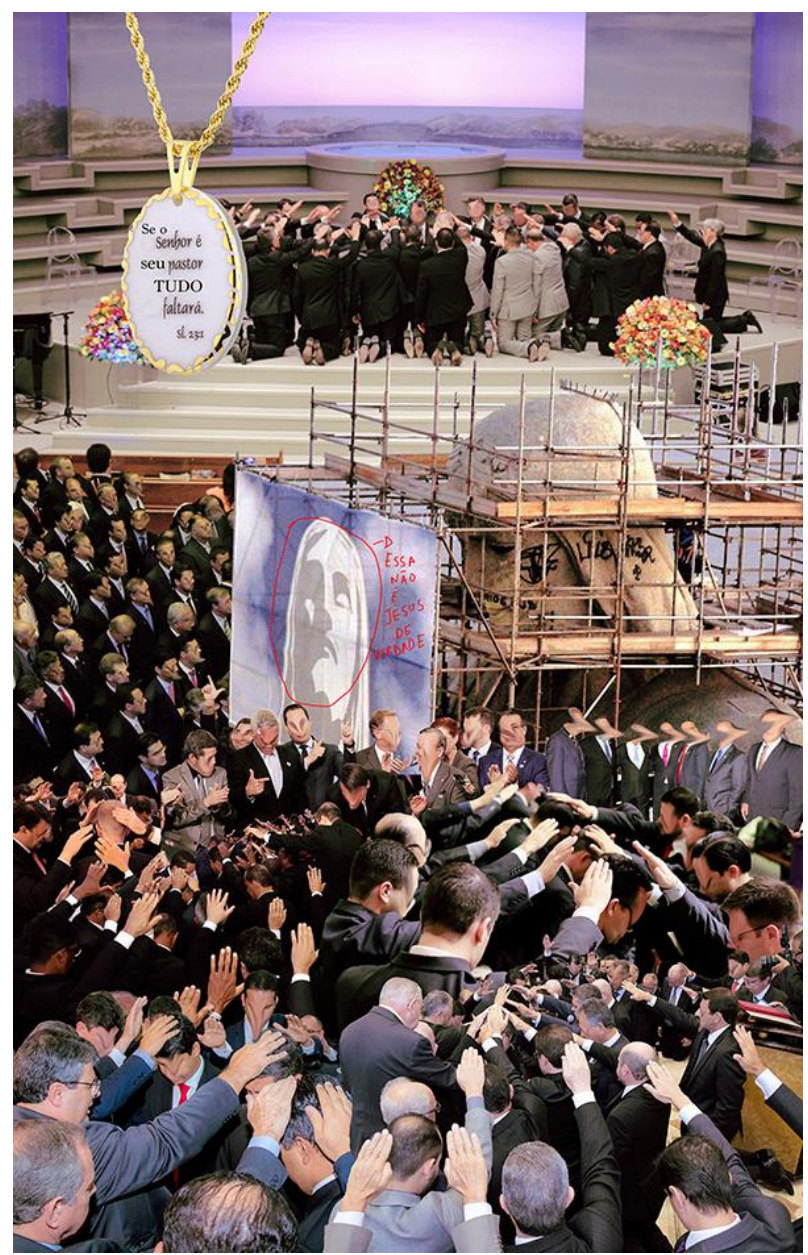

Figura 8 - Série "Sonda", de Ventura Profana, 2020.

Não é a primeira vez que Ventura Profana insere a controversa figura de Jair Bolsonaro em um de seus trabalhos. Em 2017, a artista produziu a obra BATISMO, um estudo em vermelho, uma colagem digital composta com fragmentos de registros do batismo evangélico do então deputado federal. Na montagem, a água do rio que serviu de batistério para o político é manipulada para o tom de vermelho, em alusão à violência engendrada pelo discurso de ódio que marca a tônica bolsonarista. A liturgia se configurou como uma encenação eleitoreira, já que Bolsonaro continuou a se afirmar publicamente como católico, e marcou simbolicamente a parceria do político de extrema-direita com a pauta moralista de diversos segmentos evangélicos, principal parcela da população que o elegeu à presidência. 


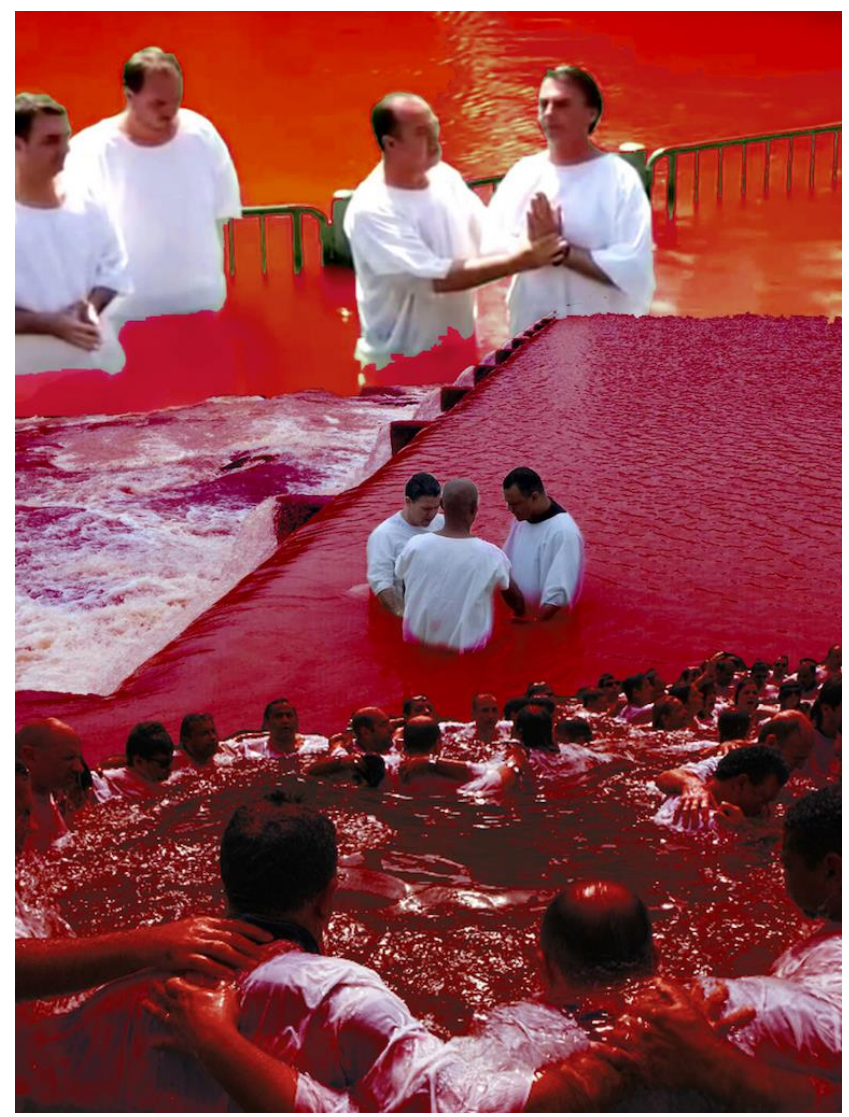

Figura 9 - Obra "BATISMO - um estudo em vermelho", de Ventura Profana, 2017

Em Lugar de falo (2017) e Corpo Universal (2018), Ventura Profana retoma à logomarca da Igreja Universal do Reino de Deus para produzir novas séries de colagens. Em ambas as obras,o corpo da artista aparecedestacado. Em Lugar de falo (um trocadilho com a expressão "lugar de fala", da filósofa Djamila Ribeiro, popularizado no contexto brasileiro dos ativismos identitários), Ventura aparece de joelhos, com o rosto colado ao chão, entre imagens de presidiários que estão em clássica posição de revista carcerária. No canto direito da obra, vê-se um cartaz com o emblema da IURD e o famoso slogan "Pare de sofrer". Complementam a colagem imagens de religiosos com seus trajes típicos de liderança e - novamente aparece uma representação de uma obra de Michelangelo. Dentre as figuras masculinas de Davi, da população negra de detentos e pastores evangélicos se consagrando, destaca-se a figura curvada de Ventura, vestida com uma camisa que em suas costas expõe a frase: "Jesus Transforma". 


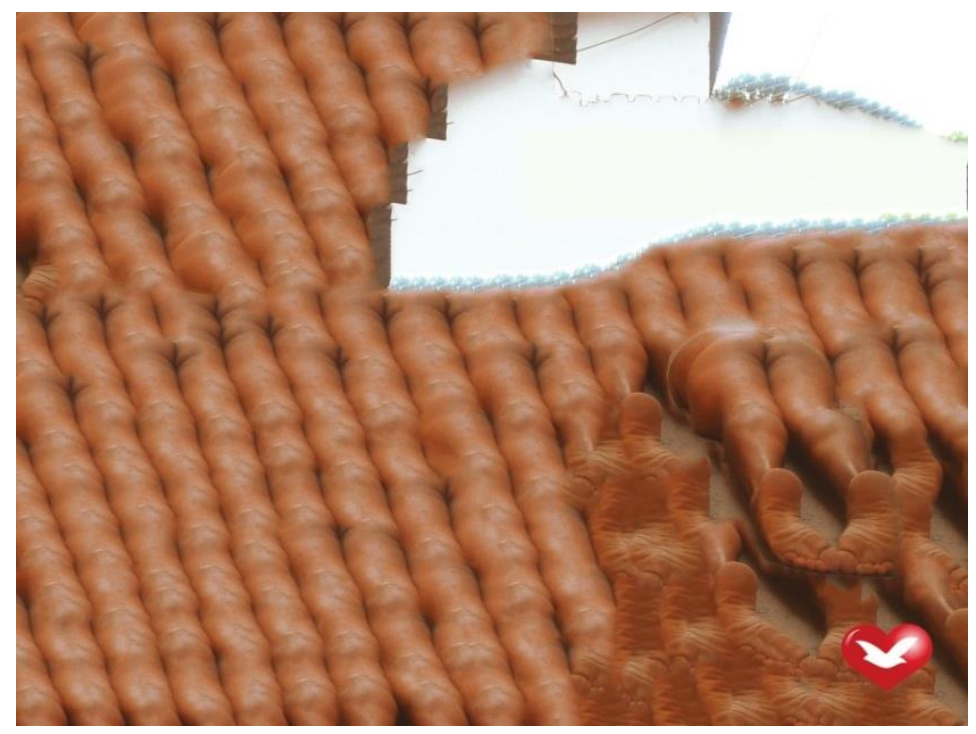

Figura 10 - Obra "Corpo universal", de Ventura Profana, 2018.

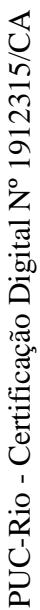

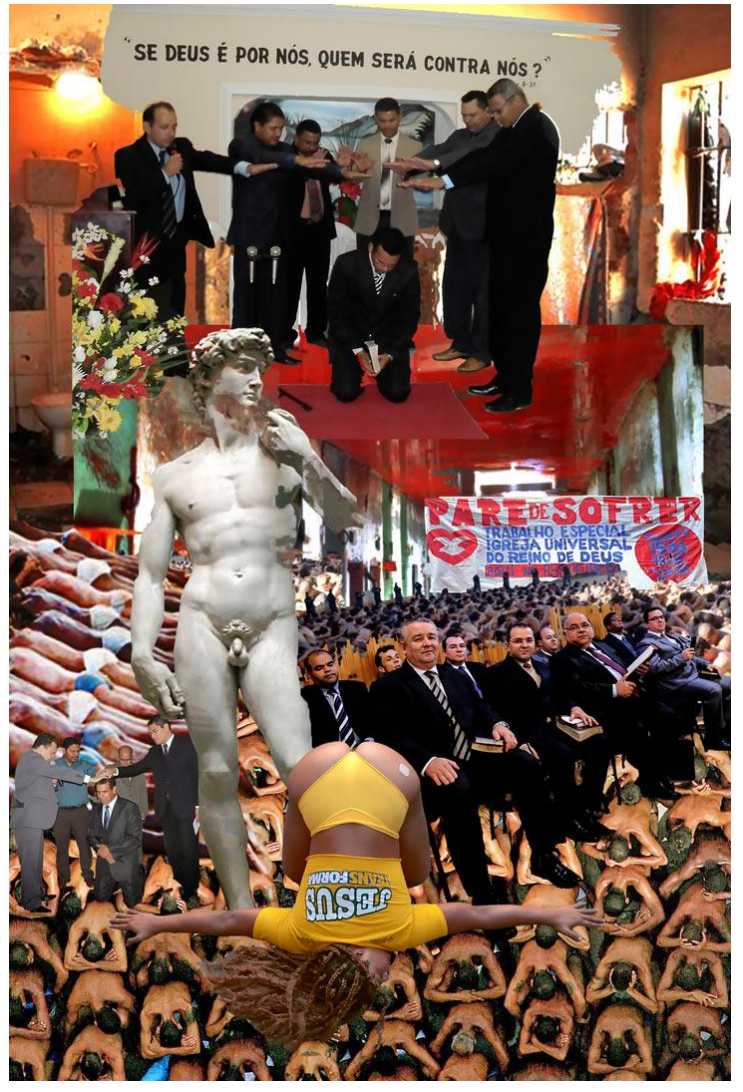

Figura 11 - Obra "Lugar de falo", de Ventura Profana, 2017. 
Em seus trabalhos de colagens, ao sobrepor seu corpo (e outras representações de corpos negros) a referências políticas conservadoras, e religiosas fundamentalistas, Ventura Profana elabora ambientes ficcionais que, por fim, retratam uma hiperralidade colonial contra a qual toda a obra da artista está posicionada. Adiante, abordaremos a temática das narrativas superficcionais propostas pelo artista Guerreiro do Divino Amor, articulando a produção dos dois trabalhos em seu ponto comum: fabulações pentecostais apocalípticas.

\subsection{Superficções Pentecostais}

Em 2016, no mesmo ano em que foi produzida a obra Universal é o reino das bichas, de Ventura Profana, a logomarca da IURD voltaria a aparecer em outro notável trabalho de arte contemporânea brasileira, desta vez na obra do artista suíço radicado no Rio de Janeiro, Guerreiro do Divino Amor. Frequentemente citada como referência pela própria Ventura, a obra de Guerreiro se articula ao trabalho da pastora, especialmente por explorar o tema das representações evangélicas como disputas de poder e elaborar fabulações apocalípticas a partir das referências pentecostais. Guerreiro e Ventura estiveram juntos como artistas residentes do projeto Bolsa Pampulha, em 2019. Mais adiante, abordaremos sobre o projeto apresentado por Ventura na ocasião da residência em Belo Horizonte.

A obra SupeRio Superficções, de Guerreiro do Divino Amor, apresentada nos formatos audiovisual, revista impressa e em painel instalativo de backlight, traz a pomba branca e a logomarca da Igreja Universal na seção Espelho Divino, localizada na parte direita do mapa superficcional carioca. O trabalho faz parte da série Atlas Superficcional Mundial, que vem sendo realizado há mais de 15 anos, na qual o artista propõe um audacioso projeto de construir um mapeamento mundial com narrativas ficcionais (ou hiper-realistas, como sugere Guerreiro). Na série, Guerreiro do Divino Amor investiga como ficções de diferentes naturezas, sejam elas geográficas, sociais, midiáticas, políticas ou religiosas interferem na constituição do território e do imaginário coletivo.

Segundo sinopse oficial: "SuperRio é o gêmeo superficcional do Rio de Janeiro; um ecossistema de Superficções que interferem na construção da cidade e do imaginário coletivo". O trabalho é composto por narrativas ficcionais elaboradas 
por Guerreiro do Divino Amor, que tratam de mitos fundantes da sociedade brasileira, como a fictícia democracia racial ou a meritocracia. No SuperRio, a tensão racial está simbolizada na figura estruturante do InfraRio, que é o substrato sobre o qual se constrói o Rio superficcional. Ele vem à tona em forma de supererupções dos supervulcões. Tal substrato é composto pela superescravidão, que rege inconscientemente as relações humanas e estrutura a sociedade supercarioca. Aparecem no trabalho outras narrativas ficcionais, como as Supermídias (vistas com papel primordial no ecossistema supercarioca, pois encenam, caracterizam e multiplicam as superficções. Atuam como inúmeras camadas nebulosas modificando a percepção da realidade); as Supersexy (principal produto de exportação. Talvez seja o vento superficcional mais famoso internacionalmente. Um mundo de beleza e sensualidade à flor da pele, propagado ao infinito pelas supermídias), o Supermedo (que é a sombra que paira sobre a cidade e os habitantes. É um sentimento polimorfo que influencia o comportamento humano), dentre outras ficcionais/hiperreais elaborações que deflagram aspectos destacados da formação social e cultural da cidade superexposta do Rio de Janeiro. Refletindo todas as superficções cariocas, no canto do quadro, está o Espelho Divino, onde:

(...) se encontra SuperDeus, uma dimensão paralela que contém a tradução divinizada de todas as superficções do SuperRio. É a sociedade paralela superfundamentalista. Os discípulos do SuperDeus se atiram numa supercruzada para empurrar o Espelho Divino para mais além possível e conquistar o universo supercarioca. Constitui um ecossistema complexo, repleto de guerras intestinas e com cosmogonia própria ${ }^{33}$.

No Espelho Divino aparecem as representações de duas pombas em conflito bélico, uma simbolizando a Superuniversal (em alusão à IURD) e a outra a Superassembleia (sobre a Igreja Assembleia de Deus), dois dos maiores grupos evangélicos em atuação no Rio de Janeiro, que correspondem a dois impérios superpoderosos neopentecostais (embora a Igreja Assembleia de Deus tenha congregações tradicionais identificadas como pentecostais tradicionais).A despeito da heterogeneidade dos grupos religiosos, ambas se uniram politicamente na

\footnotetext{
${ }^{33} \mathrm{https}: / /$ www.guerreirododivinoamor.com/superrio-filme
} 
eleição do bispo Marcelo Crivella para a prefeitura da cidade do Rio, derrotando o candidato progressista Marcelo Freixo, no segundo turno das eleições de 2016.

No vídeo SuperRio Superficções, disponível no site oficial ${ }^{34}$ do Guerreiro do Divino Amor, uma apresentadora digital de telejornal (em um avatar de mulher negra) vai descrevendo os pontos superficcionais elaborados pelo artista. A imagem da âncora virtual na frente do mapa superficcionalda cidade do Rio, como uma garota do tempo de uma realidade distópica, é complementada por imagens de registros audiovisuais da internet, de arquivos oficiais e de campanhas publicitárias. O material compõe um panorama histórico recente da cidade, no qual as superficções, na verdade, vão se configurando como documentos de uma distopia já em curso.

Na seção Espelho Divino, imagens do maior evento evangélico realizado no Brasil, a anual Marcha Para Jesus ${ }^{35}$, apresentam a festividade da multidão de fiéis pelas ruas do Centro da cidade do Rio, em 2015. Nos registros, a edição do artista destaca a promiscua relação entre os líderes religiosos e políticos, como na imagem do Pastor Silas Malafaia, saudando o então Presidente da Câmara dos Deputados, o também evangélico Eduardo Cunha, em um palco montado no Sambódromo do Rio de Janeiro. Eduardo discursa para milhares de fiéis aglomerados na Apoteose: "Deus me colocou lá (na presidência da Câmara dos Deputados). Eu sempre digo, Silas, se Deus me colocou lá, ele saberá honrar o que Ele fez". O tema da Marcha pra Jesus em 2015 foi "Pela família, pelo Brasil e contra a corrupção". Em março de 2017, Eduardo Cunha foi condenado em 1aㅡ instância à 15 anos e quatro meses de reclusão pelos crimes de corrupção passiva, lavagem de dinheiro e evasão de divisas.

As referências aos símbolos neopentecostais são aparições recorrentes no trabalho de Guerreiro do Divino Amor. A história por trás do nome artístico deflagra

\footnotetext{
${ }^{34}$ https://www.guerreirododivinoamor.com/superrio-filme

${ }^{35}$ A Marcha para Jesus é um evento internacional e interdenominacional (ou seja, realizado conjuntamente por diversas denominações evangélicas) que ocorre anualmente em milhares de cidades espalhadas pelo mundo. Com finalidade de reunir fiéis de várias denominações protestantes, a Marcha para Jesus é organizada, no Brasil, pela Igreja Renascer em Cristo(com participação de outras denominações neopentecostais). $O$ evento traz à rua as igrejas, que marcham atrás de trios elétricos. Com participação de vários estados do Brasil, reúnem-se caravanas (nome designado aos grupos de viajantes, peregrinos) de diversos lugares.
} 
a relação biográfica de Guerreiro com as igrejas evangélicas. Em entrevista para a revista ARTE!Brasileiros ${ }^{36}$, em 2019, o artista revela:

\begin{abstract}
"Guerreiro é meu sobrenome mesmo. Já Divino Amor foi uma brincadeira que surgiu quando eu era adolescente e meu pai namorava uma pastora. Ela queria me colocar para dentro da igreja, e foi um pouco uma provocação, eu queria montar uma banda de heavy metal para atuar na igreja. Nunca aconteceu, mas gostei muito do nome, Guerreiro do Divino Amor",
\end{abstract}

$\mathrm{Na}$ mesma conversa, quando perguntado se nunca havia pensado em se associar a uma igreja evangélica, o artista confessou: "Não. Na verdade eu fiquei muito curioso com aquele universo neopentecostal, que eu não conhecia bem. Foi um dos motores do meu trabalho, tentar entender aquela fé arrebatadora e ao mesmo tempo com uma estética muito forte, colorida. Era envolvente".

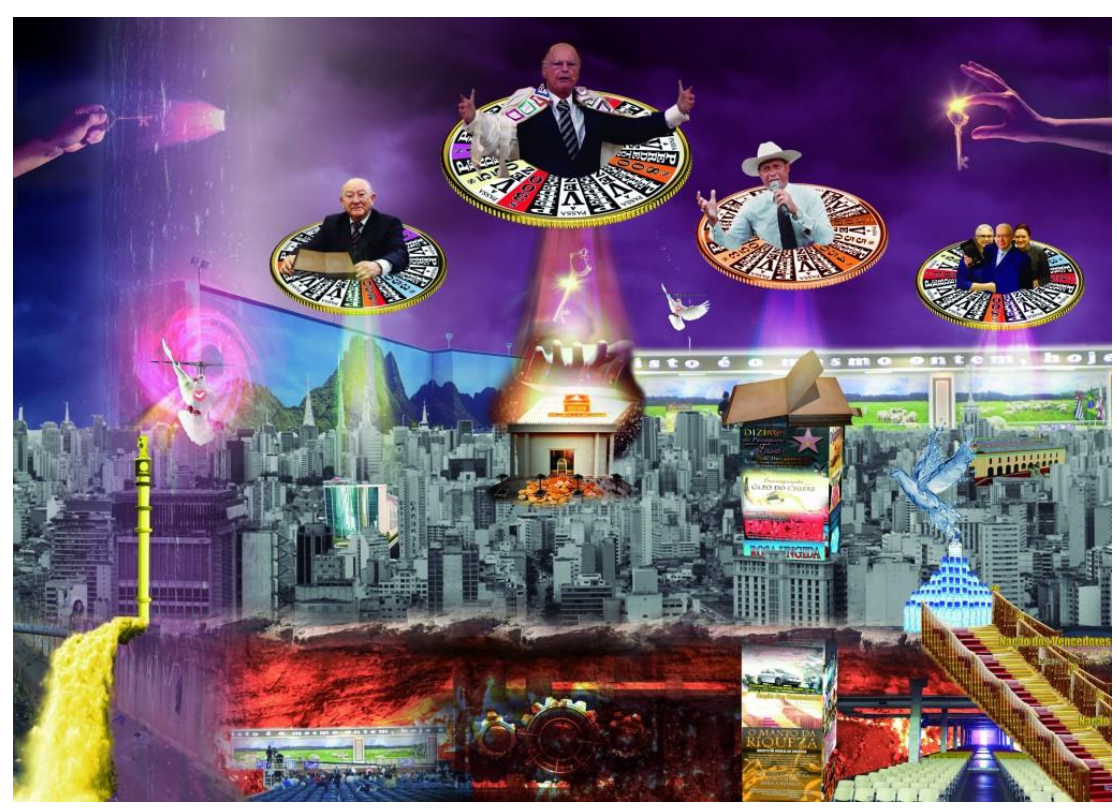

Figura 12 - "Cosmogonia superdivina", de Guerreiro do Divino Amor, 2018.

Com uma estética bastante peculiar, muitas vezes satírica, cheia de referências ao universo da internet, cores fortes e luzes LED, Guerreiro do Divino

\footnotetext{
${ }^{36} \mathrm{https} / / /$ artebrasileiros.com.br/arte/premio/a-realidade-escancarada-na-ficcao-de-guerreiro-do-divinoamor/
} 
Amor desenvolve em sua obra, através de uma abordagem kitsch e pop, reflexões sobre como cada segmento social e cultural cria uma estética ficcional que carrega consigo códigos bem definidos e próprios a cada grupo. A pesquisa artística de Guerreiro do Divino Amor, ao destacar o poder discursivo dos símbolos e signos na formação social, evoca discussões prementes da contemporaneidade como as noções pós-modernas de estética no âmbito das artes e a influência da "cultura de massa" na constituição da subjetividade dos indivíduos e comunidades.

Sobre a escolha por uma estética marcada pelo excesso, Guerreiro do Divino Amor responde à pergunta elaborada pelo curador Luiz Camillo Osório, publicada no site ${ }^{37}$ do Prêmio Pipa, em 2019, ano em que o artista suíço-brasileiro venceu a premiação na categoria do júri especializado.

\section{(LCO) O excesso visual é uma política ou uma estética?}

(GDA) Acho que é a consequência de um processo natural. O trabalho tenta dar conta de fenômenos e disputas de poder muito complexos, envolvendo muitas camadas. Esse excesso é o reflexo da justaposição dessas camadas interligadas, como um caleidoscópio. O trabalho trata de questões que não são nada abstratas, então não teria sentido levá-lo para esse campo. O resultado não poderia ser minimalista. Essa visualidade mais pop ajuda também o trabalho a perpassar os limites da arte. Fico muito feliz de ser muito usado em sala de aula, dele circular por todo tipo de ambiente. Além disso também existe, como falei mais acima, uma crítica intrínseca à noção de "bom gosto" que subjaz todo o trabalho, para além dos temas que abordo.

A resposta indisciplinada de Guerreiro ao curador e crítico de arte acaba por destacar não apenas a estratégia comunicativa de seu trabalho, mas também a clareza com a qual o artista reflete e elabora sobre a supercomplexa (com pertinência dessa apropriação) relação entre aspectos da atuação neopentecostal, através das ferramentas de comunicação em massa, seus projetos de poder, e as representações estéticas desse fenômeno superbrasileiro. O posicionamento de Guerreiro, frontalmente contra o "bom gosto canônico das artes", diante da pergunta especializada e institucional (vale a pena ler toda a entrevista), por sua vez, revela muito sobre os motivos pelos quais a estética evangélica (muitas vezes considerada

\footnotetext{
${ }^{37}$ https://www.premiopipa.com/2019/08/luiz-camillo-osorio-conversa-com-guerreiro-do-divino-amor/
} 
cafona, precária, excessiva) esteve desde sempre sub-representada nas narrativas artísticas contemporâneas, a despeito da onipresença midiática.

A distância entre o universo brasileiro das artes visuais - especialmente quando consideramos os ambientes institucionalizados e seus recortes curatoriais e os símbolos evangélicos, marcou a polêmica recepção do trabalho Terremoto Santo, de Bárbara Wagner e Benjamin de Burca, exibido pela primeira vez em 2017. Um emblemático episódio que expõe não apenas a lacuna de contatos entre o fenômeno da expansão pentecostal no Brasil e as escassas representações evangélicas no contexto institucional das artes. A recepção controversa de Terremoto Santo evidencia velhos tensionamentos da arte em seus desdobramentos políticos: a inserção nos circuitos de exibição, a recepção e relação com o público e as múltiplas possibilidades de interpretação e apropriação das obras.

\subsection{Terremoto Santo}

Em março de 2018, a sede do Instituto Moreira Salles no Rio de Janeiro inaugurou a exposição coletiva Corpo a Corpo: a disputa das imagens, da fotografia à transmissão ao vivo, composta por trabalhos de artistas brasileiros que tratam de aspectos contemporâneos da produção imagética no país. Naquela noite, o imponente casarão modernista localizado na Zona Sul carioca ficou movimentado com dezenas de pessoas que, assim como eu, foram conferir a mostra que contava com obras de artistas como Bárbara Wagner e Benjamin de Burca, Jonathas de Andrade, Sofia Borges, Letícia Ramos, e dos coletivos Garapa e Mídia Ninja. O projeto foi idealizado pelo curador Thyago Nogueira, coordenador de fotografia contemporânea do IMS e editor da revista ZUM, e contou com assistência de Valentina Tong. A exposição já havia sido apresentada poucos meses antes na sede paulista do IMS e, ao desembarcar no Rio, já estava sendo recebida com uma grande expectativa do público por conta do sucesso da exibição em São Paulo. A mostra em cartaz no Instituto Moreira Salles foi apresentada oficialmente pelo curador como:

um retrato, individual ou coletivo sobre como as imagens podem nos ajudar a enxergar os conflitos sociais que emergiram no Brasil nos últimos anos. O mote é o uso do corpo como um elemento de representação social e atuação 
política - seja pela presença física e simbólica nos espaços públicos, seja como o veículo condutor da câmera, seja como lugar de expressão da individualidade, que aproxima e separa os indivíduos. ${ }^{38}$

Bárbara Wagner, artista brasiliense radicada no Recife, importante tópico desta pesquisa de dissertação, participou do projeto com dois trabalhos: A procura do $5^{\circ}$ elemento (2017), uma série de fotografias produzidas por Bárbara, que acompanhou uma seleção de MCs organizada pela produtora KL, de São Paulo, como um concurso nos moldes de reality show; e o curta-metragem Terremoto Santo (2017), realizado em parceria com o artista alemão Benjamin de Burca, que retrata o universo pentecostal na Zona da Mata pernambucana. Dedico-me agora a tratar do impacto que o filme de Bárbara e Benjamin teve na minha experiência pessoal (e consequente influência nos caminhos desse estudo), destacando também como o trabalho ainda tem sido recebido com reações afloradas, evidenciando sua pertinência provocativa e potência comunicativa.

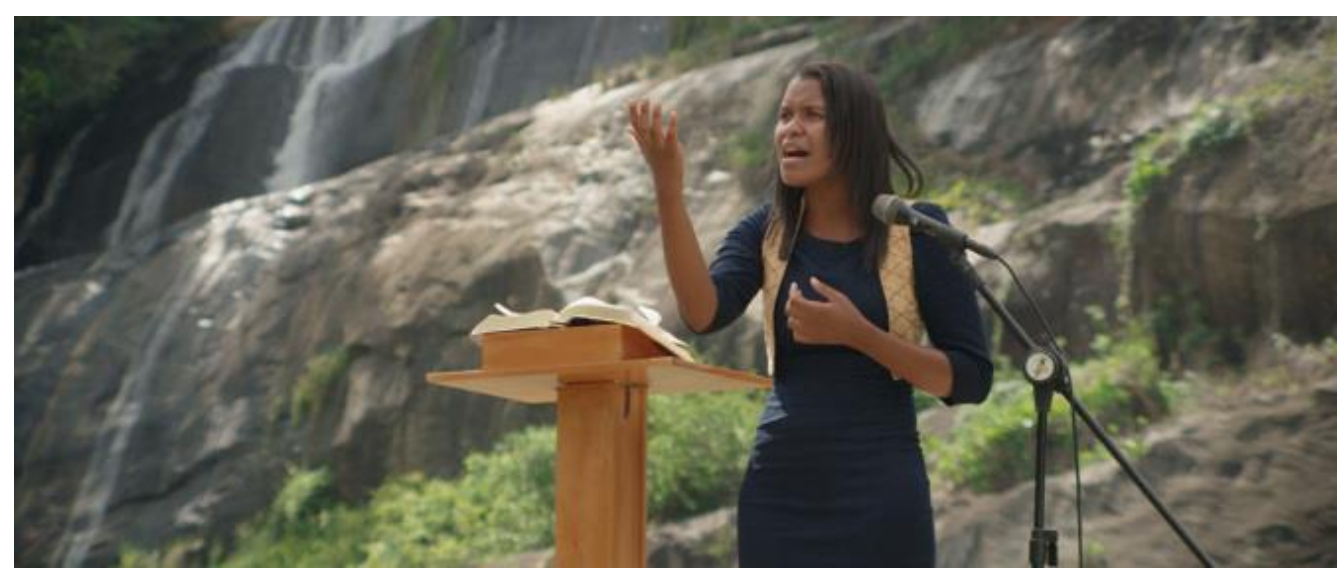

Figura 13 - Frame da obra "Terremoto Santo", de Bárbara Wagner e Benjamin de Burca, 2017.

Terremoto Santo é um filme musical no qual Bárbara e Benjamin produziram uma série de videoclipes a partir de uma parceria com a gravadora de música gospel Mata Sul, localizada na cidade de Palmares, em Pernambuco. O trabalho destaca o fenômeno gospel como a manifestação cultural mais ativa na região da

\footnotetext{
${ }^{38}$ https://ims.com.br/exposicao/corpo-a-corpo-ims-rj/
} 
Zona da Mata de Pernambuco, onde a cultura pentecostal se espraiou com maior rapidez, graças à difusão das músicas pela rádio da cidade. Terremoto Santo se utiliza de um conjunto de recursos técnicos, estéticos e narrativos recorrentes no trabalho de Bárbara. Com uma fotografia cinematográfica e um fino acabamento sonoro, o curta-metragem musical de quase vinte minutos transita livremente - e estrategicamente - entre a ficção e o documentário. Essa tem sido uma característica notável nos projetos da artista, que tem formação acadêmica e histórico profissional em jornalismo, e que comumente articula a linguagem documental às suas proposições artísticas. Por consequência disso, as obras de Bárbara Wagner têm tido forte inserção, tanto no circuito das artes visuais quanto no contexto de festivais de cinema. Em entrevista ao site do Prêmio Pipa, em 2017, ano em que se sagrou vencedora da premiação (assim como Guerreiro do Divino Amor no ano seguinte), Bárbara fala um pouco sobre sua relação interseccional com a fotografia documental, os produtos de comunicação de massa e o contexto das artes visuais, reforçando seu interesse pelas imagens clichês:

Como fotojornalista, desenvolvi um gosto pela leitura crítica
de estereótipos e clichês, formas que de tão sintéticas
parecem realidades 'dadas'. Sem me adequar nem aos
meios massivos nem às belas artes, fui
experimentando fazer fotografia entre esses dois circuitos,
não só construindo 'imagens do real'; mas, sobretudo,
atentando à 'realidade das imagens'

Sobre o filme Terremoto Santo, o roteiro é uma compilação não sequenciada de videoclipes, cada um explorando diferentes recursos cênicos e simbólicos das manifestações pentecostais. Na abertura do curta-metragem, ainda sem imagens projetadas na tela, ouve-se em off o barulho do canto de pássaros e das águas correntes de um rio. Aos poucos as imagens vão se configurando. Vê-se então um homem de costas, vestindo um traje social típico das igrejas pentecostais tradicionais. A locação é de uma paisagem natural, com montes e rios, localizada na Zona da Mata. O rapaz vira e caminha em direção à câmera, chegando à beira do rio, onde, segurando uma flor, senta-se sobre uma pedra. Começa então uma trilha sonora. A música começa, uma voz feminina entoa um louvor. O rapaz joga então a flor no pequeno rio e a imagem corta para a cantora evangélica. Ela aparece cantando de frente para a câmera, gesticulando ilustrativamente a letrada canção.

\footnotetext{
${ }^{39}$ https://www.premiopipa.com/pag/artistas/barbara-wagner/entrevista-com-barbara-wagner-transcricao/
} 
Vemos então na tela o título da obra "Terremoto Santo". A essa cena inicial, sucedem-se algumas cenas de louvor. Em um programa de rádio, a oração de um homem que parece ser um pastor precede três canções de louvor cantadas à capela nos estúdios. Uma placa em neon anuncia que estamos "no ar". Logo depois, assistimos a uma sucessão de clipes musicais, muitos dos quais tendo uma natureza exuberante por cenário. O último clipe é gravado em uma locação interna: uma igreja em construção. Uma evidente metáfora sobre a consistente expansão evangélica que produz cada vez mais novos templos e denominações no Brasil.

A recepção de Terremoto Santo foi marcada (e ainda tem sido) pelo debate sobre qual postura o público e a crítica deveriam tomar diante da polivalência das imagens produzidas por Bárbara. Para meu desconcerto e perplexidade, a sessão de estreia no IMS carioca, na qual estive presente, foi recebida com risadas e alguns comentários de reprovação pelos corredores do casarão modernista que abriga o espaço cultural. O desgosto por parte do público eu assimilei com certa facilidade, afinal, o que estava ali projetado na tela era o retrato bastante verossímil de uma realidade sociocultural e religiosa que por anos foi evitada pelos espaços elitistas artísticos e intelectuais. Os risos, porém, ficaram ecoando por alguns dias na minha cabeça.

Eu não havia apreendido imediatamente todas as questões que o filme de Bárbara e Benjamin suscitavam, mas já nos primeiros contatos com a obra fiquei bastante tocado e empolgado por aquela presença evangélica "inconveniente" promovida pela estadia de Terremoto Santo no IMS. Saí da exposição excitado, conversando com alguns amigos - que também estavam na mostra - sobre minha surpresa com a reação do público da Gávea. Instigava-me, mesmo que com alguma pronta desconfiança, ver aquele recorte de manifestações tão familiares, deslocado para um contexto estranho a esse repertório de símbolos. Soube depois, pela internet, que a exibição do filme no festival Janela de Cinema do Recife, em 2017, também havia sido recebida com risos de escárnio- e até vaias de indignação por parte do público presente e reprovação de alguns críticos de arte. Em um texto publicado por ocasião da oficina de crítica oficial do festival de cinema, de autoria da pesquisadora Bárbara Bergamaschi, foi questionado o pacto que o filme estabelece com seu espectador. Com quais ferramentas os sujeitos inseridos no contexto do circuito institucionalizado das artes - pertencentes a outro contexto sociocultural, com pouco contato com esse repertório religioso - fariam a leitura dessas imagens? 
"As personagens de Terremoto Santo não parecem estar conscientes do porque estarem sendo retratados ali (...) os retratados não parecem ter participado dos procedimentos de mise-en-scène em que foram inseridos”, provoca Bergamaschi.

Outro episódio polêmico aconteceu em 2018, na Berlinale, o prestigioso festival de cinema de Berlim. Dessa vez, não porque nele se identificasse um tom cômico e pouco empático com os atores. Muito pelo contrário, houve quem acusasse o filme de ser cúmplice e propagador de um discurso religioso conservador. Os diretores estariam, segundo os críticos, visibilizando um problemático discurso fundamentalista sem que uma crítica a ele fosse claramente formulada.

Uma das cenas que concentrou maior parte das argumentações contrárias ao trabalho de Bárbara e Benjamin foi o momento em que Tacy Silva canta a música tema da obra, Terremoto Santo, um louvor que trata da libertação espiritual através da entoação de cânticos de adoração. "Vai tremer esse lugar com a unção e o poder que o nosso Deus aqui vai derramar", diz a letra composta por Cícero Eraldo. Quando a canção atinge seu clímax, a câmera, comandada por Pedro Sotero, treme, em linguagem análoga à metáfora do louvor. Embora muitos espectadores condenem à escolha do recurso técnico e linguístico, a intérprete gospel sai em defesa do trabalho: "Achei bem interessante porque tem tudo a ver com a canção e, principalmente, por acontecer no ápice da música, naquela

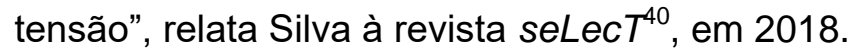

Em entrevista para o curador da mostra Corpo a Corpo, Thyago Nogueira, em 2017, o diretor Benjamin de Burca detalha o processo de criação, de parceria com os cantores. Segundo Burca, eles propuseram um trabalho coletivo na concepção do roteiro e na elaboração estética do filme, e as "decisões foram tomadas em conjunto e não levaram em conta apenas as capacidades e talentos, mas também as relações já existentes entre os membros do grupo e suas atuações na igreja e nas comunidades".

Sobre a performance dos atores, a atuação foi idealizada por eles mesmos, que sugeriram locações, planos e repertório musical, configurando-os como coautores do projeto. Benjamin destaca que "o filme toma um espaço híbrido: é documental quando os personagens representam a si mesmos tornando pública sua fé e é ficcional à medida que evidencia a construção teatral das performances".

\footnotetext{
${ }^{40}$ https://www.select.art.br/barbara-wagner-e-benjamin-de-burca-pelos-seus-colaboradores/
} 
Ademais, Bárbara Wagner reforça que o trabalho não pretende ser uma abordagem generalizada do fenômeno pentecostal no Brasil. Ao contrário, a artista, em entrevista virtual no canal do YouTube do projeto Escola da Cidade, para o arquiteto e professor Gulherme Wisnik, em 2020, destacou que o projeto era é um recorte muito específico territorial e culturalmente:

Uma coisa importante pra falar (...) e aí a gente abre um pouco essa percepção por que o Terremoto dividiu muito as opiniões desde 2017 até agora. O filme aborda muito especificamente a prática pentecostal da Assembleia de Deus na Zona da Mata pernambucana. Então é muito específico, muito recortado. A gente gosta de falar disso porque normalmente as pessoas entendem o trabalho como uma abordagem da igreja evangélica ou do crescimento evangélico no país. $E$ isso está ali, mas a gente está num lugar muito mais fechado (...). E a Assembleia de Deus, que é uma das igrejas evangélicas mais antigas do Brasil, tem uma liturgia que é muito complexa ${ }^{41}$.

A fala de Bárbara Wagner na entrevista a Wisnik expõe o cuidado que a artista tem ao desenvolver sua narrativa de modo que, partindo de conceitos e abordagens estereotipadas sobre grupos emergentes da nova Classe $\mathrm{C}$ brasileira, não recaia justamente à superficialidade com a qual esses sujeitos ficam submetidos por representações externas. Bárbara busca em seus projetos, portanto, destacar as idiossincrasias dos corpos que estão à margem das instâncias intelectuais do país, mas que, alternativamente e autonomamente, configuram outras centralidades artísticas e culturais. O que fica muito latente no fato da recepção controversa do público ao filme Terremoto Santo é, portanto, uma indolência por parte da crítica e dos espectadores em não conseguir descolar a representação do grupo de pentecostais retratados no filme com uma ideia generalizada do que é ser evangélico no Brasil.

Vale destacar que o potencial provocativo do filme Terremoto Santo é estratégica e cuidadosamente trabalhado por Bárbara e Benjamin nos detalhes da realização do projeto. Na construção da linguagem, os autores optaram pela manutenção da convenção técnica, valendo-se de recursos simples da publicidade e do jornalismo (escola de Bárbara), sendo o uso do flash, associado à luz

\footnotetext{
${ }^{41} \mathrm{https}: / /$ www.youtube.com/watch?v=80mlglxrsZA
} 
ambiente, talvez o mais explícito desses gestos. A operação política estaria, em contrapartida, no caráter simbólico do ato de lançar luz, evidenciar as cores, realçar os contrastes, marcar os contornos, para destacar da multidão um indivíduo que pouco participa das narrativas hegemônicas da arte.

Em artigo publicado no site da Revista Cinética, o crítico de cinema Hermano Callou destacou aspectos da obra de Bárbara e Benjamin, em um texto chamado "Espelhos de Poder":

A abordagem em termos de tipos sociais e a lógica de inventário com que Wagner e de Burca trabalham se revela, na verdade, paródica, como um exercício de um gênero que não é mais possível. Wagner e de Burca são artistas de uma geração para quem o "corpo popular" não é mais um outro de classe a ser descoberto, muito menos a ser inventariado ou classificado. Trata-se de uma noção que nunca perde seu caráter de artefato, constituindo-se como um repertório imagético e sonoro de marcações sociais a serem trazidas à tona, observadas e deslocadas. Não é apenas questionar a imagem etnográfica em sua pretensão factual, nem tampouco criticá-la de fora, se posicionando em um espaço exterior seguro, quiçá autorizado, em que a crítica poderia ser exercida sem riscos de contaminação, mas de operar no interior dos seus mecanismos, se apropriando deles, de modo a ampliar as contaminações. ${ }^{42}$

Para entender de maneira mais aprofundada a obra Terremoto Santo, é importante situá-la como um desdobramento da pesquisa da artista brasiliense, radicada no Recife, que se dedica a investigar aspectos sociais e estéticos da prática pentecostal no Brasil, dentro de uma investigação mais ampla sobre manifestações das camadas sociais emergentes do Brasil no século XXI. Em 2014, Bárbara Wagner já havia apresentado o projeto Crentes e Pregadores, uma série de 16 fotografias retratando preletores evangélicos em seus ambientes familiares: casa, quintais, rua, igrejas. A artista apresenta o trabalho como:

Uma investigação sobre o fenômeno do crescimento das igrejas evangélicas no Brasil (que subiu de $5 \%$ na década de 1970 para $22 \%$ hoje) e a relação estreita do evangelismo com o que ficou conhecido como a "nova classe média" do país. [...] Com atenção às representações de coletividade na

\footnotetext{
${ }^{42}$ http://revistacinetica.com.br/nova/espelhos-do-poder/
} 
cultura popular e nas tradições que se reinventam o tempo todo nas ruas, sem regras e sem muitos pudores ${ }^{43}$.

A série apresenta pastores e fiéis evangélicos em retratos individuais, com um enquadramento que remete tipologicamente à fotografia etnográfica: corpos dispostos em pose frontal, centralizados, registrados em seus ambientes comuns. Destaca-se, novamente, o uso de flash, mesmo nas locações diurnas, dando ao resultado características de material publicitário/jornalístico, revelando um desejo de que aquelas imagens fossem deslocadas para outro regime de valoração, onde poderiam ser vistos por um certo imaginário do sucesso, da moda, de reconhecimento. O gesto de realocação não apenas questiona os regimes de visibilidade tradicionais do corpo popular, especialmente dos grupos evangélicos, mas permite que aquelas poses revelem a discreta insubordinação que manifestam diante de todo olhar classificatório.

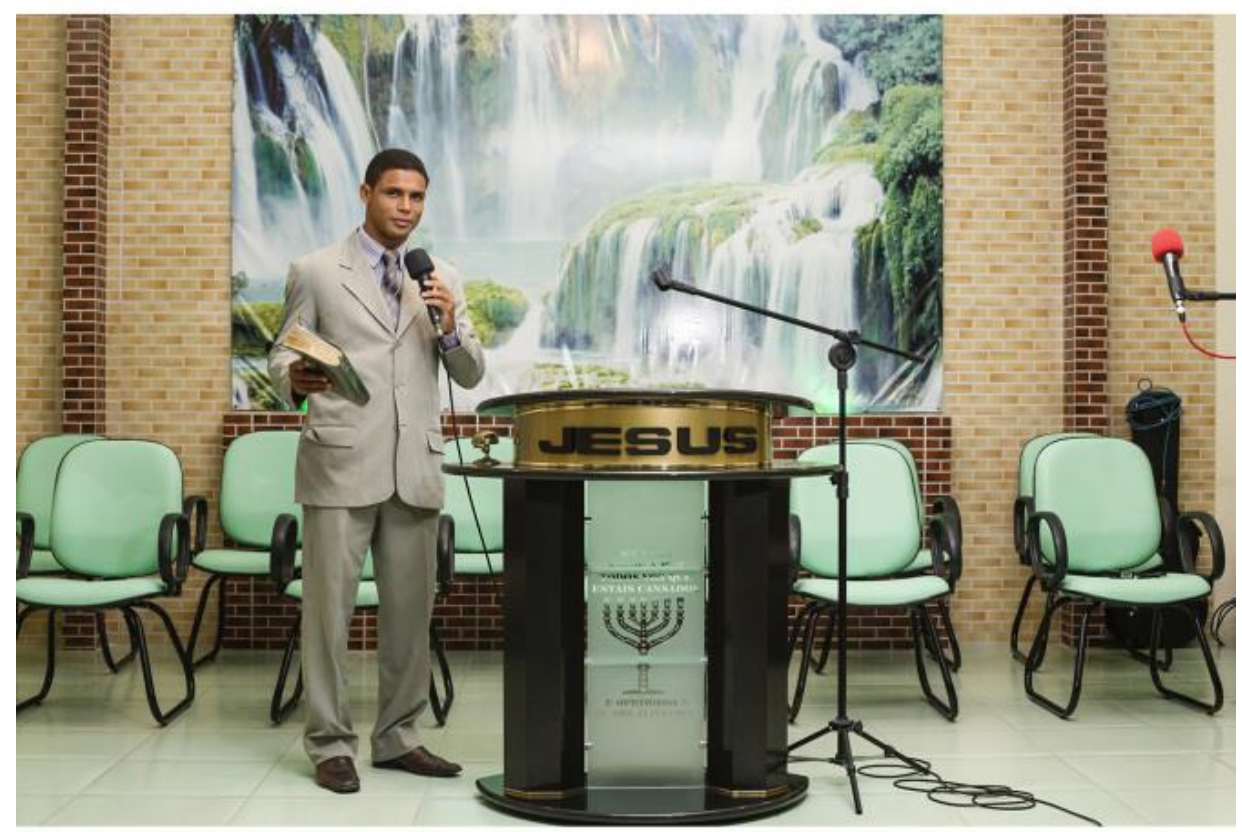

Figura 14 - Obra da série "Crentes e pregadores", de Bárbara Wagner, 2014.

\footnotetext{
${ }^{43}$ https://www.barbarawagner.com.br/Crentes-e-Pregadores-Believers-and-Truthsayers
} 
Como vimos em capítulos anteriores, o distanciamento entre esses dois universos (das igrejas evangélicas e das artes no contexto institucionalizado) não é apenas ocasional, mas, antes de tudo, deliberado e constituído historicamente pelo excludente processo de formação, produção e difusão das práticas artísticas no Brasil. Ao deslocar o repertório superpopular (aqui estrategicamente aludindo a Guerreiro do Divino Amor) de símbolos pentecostais, (frequentemente associados ao "cafona", "conservador" e "kistch" pelas elites intelectuais e artísticas), para os ainda restritos ambientes das instituições de artes e os festivais de cinema, Bárbara e Benjamin provocam um choque sociocultural. A força reflexiva de Terremoto Santo se destaca, justamente, por promover o desconforto do "bom gosto estético" das galerias de arte e museus, com a projeção de corpos marginalizados que se apresentam a partir de seus repertórios culturais, sem mediação - ou manipulação bem definida por parte dos autores da obra. A dificuldade de parte do público e da crítica em ver o trabalho além dos estereótipos esperados, pode ser lida como H. R. Jauss chamou de "horizontes de expectativas" isto é:

O sistema de referências objetivamente formuláveis que, para cada obra no momento da história em que ela aparece, resulta de três fatores principais: a experiência prévia que o público tem do gênero de que a obra é um exemplo, a forma e a temática de obras anteriores de que ela supõe conhecimento, e a oposição entre linguagem poética e linguagem prática, mundo imaginário e realidade cotidiana (JAUSS 1994, p. 54).

O modo de aproximação de Bárbara Wagner da estética gospel, de fato, não é apenas consciente das marcações sociais que suas imagens carregam e dos sistemas de validação de gosto que as classificam, mas é também bastante interessado em evidenciar tais marcas de distanciamento. No entanto, o que se enleva na maior parte das abordagens negativas ao trabalho Terremoto Santo é a recorrente superficialidade com a qual críticos de arte (e boa parte da elite intelectual) abordam a questão da presença evangélica no Brasil, seu crescimento exponencial e as representações desse fenômeno do âmbito artístico. 


\subsection{Sérgio e Simone}

Em 2014, a artista baiana Virgínia de Medeiros apresentou, na ocasião da 31 ${ }^{\text {a }}$ Bienal de São Paulo, o filme Sérgio e Simone \#2(2007/2014), no qual retrata, a conversão da travesti Simone no pastor evangélico Sérgio, destacando as ambiguidades dessas duas identidades. Apresentada ao público pela primeira vez em 2007, uma década antes do lançamento oficial de Terremoto Santo,a obra audiovisual de Virgínia já abordava alguns elementos que seriam marcantes também no trabalho de Bárbara Wagner e Benjamin de Burca. Os conceitos de deslocamento, participação, performance e fabulação estão presentes em Sérgio e Simone \#1 (2007/2009), primeira versão do projeto, a partir de uma narrativa ainda mais idílica do que a apresentada no musical. A linguagem híbrida entre a documentação e a narrativa ficcional é também a forma como Virgínia conta a história da identidade transitória da protagonista do filme.

Frequentemente, a obra Sérgio e Simone tem sido abordada no âmbito dos estudos de gênero, raça e sexualidade, destacada sob a perspectiva das teorias feministas e Queer ${ }^{44}$. Essa abordagem permite a aproximação da pesquisa de Virgínia com a obra de Ventura Profana - o que faremos mais adiante -, especialmente considerando outra interseção estrutural nos trabalhos das duas artistas baianas, e que se configura como centralidade nesta pesquisa: as representações sobre as emergentes manifestações religiosas pentecostais.

A pesquisa para a obra Sergio e Simone começou em 2006, quando Virgínia de Medeiros inicia uma relação com o universo das travestis, transexuais e prostitutas que vivem em Salvador. O projeto se desenvolve mais especialmente na Ladeira da Montanha, uma das áreas mais degradadas da velha Salvador, localizada próximo ao turístico Elevador Lacerda, ponto de transferência entre a cidade-alta e a cidade-baixa. Naquela época, Virgínia estava realizando o projeto StudioButterfly ${ }^{45}$ (2006-2013), no qual produziu uma série fotográfica com travestis e

\footnotetext{
${ }^{44}$ A teoria Queer surgiu na década de 1990 e teve como referencial teórico os estudos de Michel Focault e Derrida, além da contemporânea Judith Butler. Ela foi originada do encontro dos estudos culturais norte americano com o pós-estruturalismo francês. A palavra queer é traduzida por estranho, excêntrico, raro e extraordinário. Os estudos queer adquire todo seu poder com a invocação que o relaciona com patologias e insultos e representam a transgressão quanto a uma sociedade heteronormativa, destacando a realidade social e cultural de uma minoria excluída - os homossexuais. Vale ressaltar, que esta minoria luta contra a condição de marginal de forma radical, exagerada e excêntrica. Dessa forma, ser queer é pensar na ambiguidade, na multiplicidade e na fluidez das identidades sexuais e de gênero, mas, além disso, também sugere novas formas de pensar a cultura.

${ }^{45} \mathrm{http}: / /$ virginiademedeiros.com.br/obras/studio-butterfly/
} 
transexuais da região em troca do compartilhamento das histórias das retratadas pela artista.

O Studio Butterfly funcionou, durante aproximadamente um ano e meio, numa pequena sala de um edifício comercial do centro de Salvador. Ele foi pensado como um ponto de encontro entre as travestis e a artista. No estúdio, as travestis levavam suas fotos antigas e mais recentes, junto a familiares, amigos, amores; e, sentadas na "poltrona dos afetos", contavam à Virgínia algumas histórias de vida, que eram registradas em vídeo. Em troca, Virgínia fazia com elas um ensaio fotográfico, e ao final Ihes dava um book. Em entrevista dada para a Galeria Nara Roesler, publicada no YouTube em 2014, Vírginia contou um pouco sobre as motivações e o processo de criação de Studio Butterfly:

Trabalho com um dos temas acho que mais complicados de
lidar porque há sempre o risco de eu cair num exotismo, de
cair num clichê então esse é o meu maior desafio. Mas
como estou sempre trabalhando com essa ideia de
fabulação, com a ideia de estar menos preocupada com o
fato, menos preocupada com a verdade e mais interessada
em criar outro lugar, isso me protege de alguma forma. [...]
Eu estou menos interessada no testemunho e mais
interessada na capacidade que essas pessoas têm de
imaginar, de fabular, de reinventar a sua própria condição. ${ }^{46}$

Nos encontros para o projeto Studio Butterfly, Virgínia conheceu Simone, uma travesti negra que vivia nas redondezas da Ladeira da Montanha. Simone dizia ser uma espécie de guardiã de uma fonte de água pública conhecida como Fonte da Misericórdia, local que servia para as pessoas, especialmente as em situação de rua, tomarem banho e saciarem a sede. A fonte também funcionava como santuário para práticas ritualísticas do Candomblé. Para a realização de um preliminar projeto com Simone, intitulado A guardiã da Fonte (2006), Virgínia estabeleceu com a protagonista um acordo: a artista ajudaria Simone e seu companheiro na época, Maurício, a realizar uma cirurgia, pois o jovem encontrava-se com os pés quebrados por um acidente. Em troca, a travesti seria filmada e apresentaria o bairro à artista.

\footnotetext{
${ }^{46}$ Vídeo estúdio Butterfly e outras fábulas. Publicado pela galeria Nara Roesler em 17 de novembro de 2014.https://www.youtube.com/watch?v=nN5IFMAFXKE
} 
Uma negociação que destaca o delicado (e controverso) aspecto antropológico/etnográfico da pesquisa de Virgínia, jovem branca cisgênero, de classe média, com origem e vivências distantes daquele contexto de precariedade. Sobre essas nuances de sua pesquisa, Virgínia afirma: "O meu trabalho é munido de um phatos antropológico, busco conhecer um mundo diverso do meu, me considero uma artista auto-etnográfica" (MEDEIROS, 2014) ${ }^{47}$.

Nesse primeiro vídeo, brincando com a câmera, se autodirigindo, Simone performa sua feminilidade, transitando entre gestos hipersensualizados e 0 repertório místico de entidade religiosa. Sua relação com a fonte é erotizada e extravagante, onde se banha com roupa, se movimentando em meio a fogueiras improvisadas, vegetações naturais do local degradado e o resistente minadouro. As imagens que resultaram na obra "A guardiã da fonte" foram projetadas na fonte, em uma intervenção urbana pública realizada por Virgínia.

Depois de um mês desse primeiro encontro, filmado em 2007, Virgínia de Medeiros volta a contactar a travesti para pedir autorização de uso de imagem para o projeto recém-produzido. Eis que a artista tem uma surpresa. Simone, que era usuária de crack, como grande parte dos moradores daquela decadente região de Salvador, havia vivido há poucos dias uma experiência-limite, uma convulsão causada por overdose da droga. Simone conta que nessa situação de quase-morte, havia se encontrado com Deus, e que Ele, ao dar uma "segunda chance", reconverteu-a em sua identidade de batismo, chamando-o agora de Sérgio.

Sérgio performa uma identidade masculina cisgênero e heterossexual, com novas associações: agora se apresenta para o mundo como um emissário de Deus na Terra, se tornando pastor da Igreja Pentecostal do Mistério, de uma vertente também conhecida popularmente como igreja do Reteté, marcada fortemente pelo sincretismo das manifestações religiosas afro-brasileiras com características evangélicas pentecostais. Em sua nova identidade, Sérgio começa a pregar fanaticamente contra sua religião pregressa, caminhando pelas ruas de Salvador com um cartaz que trazia sua "imagem pecaminosa" de travesti, como testemunho de sua conversão e transformação. Abandona então seu antigo companheiro e volta a morar com os pais na periferia de Salvador.

Esta condição transitória de identidades marca o encontro de Virgínia com Sérgio/Simone. Após sete anos, desde o primeiro contato da artista com a/o

\footnotetext{
${ }^{47}$ http://gravuracontemporanea.com.br/artista-virgina-medeiros/
} 
protagonista do projeto, em 2014, Sérgio volta a procurar Virgínia para dizer que Simone havia ressurgido e que assumira o posto de mãe-de-santo em um terreiro em Salvador. Na época, a artista havia sido convidada para participar da 31aㅡ edição da Bienal de São Paulo, justamente com o projeto Sérgio e Simone. Após o breve contato de Sérgio, informando da coexistência de Simone naquele período, Virginia então decide informar à curadoria da Bienal que retomaria à obra para atualizações.

Nesse hiato de tempo, entre o último contato de Sérgio e Virgínia e sua volta à Salvador para documentar a suposta redesignação identitária de Sérgio em Simone, para a surpresa da artista, a travesti havia dado lugar, novamente, ao pastor pentecostal. Virgínia decide então iniciar um processo que chamou de "Igreja dos Desejos", no qual Sérgio encenaria uma pregação, na congregação idealizada especialmente para o projeto. Então a artista começou a logística da produção, ambos alugaram um espaço e iniciaram os preparativos: "(...) eu achei que ele iria comprar cortinas brancas, né, era uma Igreja. Ele comprou cortinas de paetê, o manto dele era delamê dourado" 48 .

Neste novo encontro, ficou latente que as identidades outrora polarizadas de Sérgio e Simone começavam a se integrar. Ao fundir, inesperadamente, os códigos díspares do contexto pentecostal com o universo das prostitutas e travestis da Ladeira da Montanha, Sérgio e Simone promovem à obra de Virgínia mais camadas de significantes, destacando aspectos transgressores da postura não-binária e fluida da protagonista, esgarçando os limites entre ficcionalidade e realidade contidos no projeto.

A vida cotidiana é constituída por uma armadura de condutas, marcada por uma barreira imaginária que separa indivíduos, que tem sua própria consciência encoberta por identidades-estigmas, imagens estereotipadas. A ordem que nos separa de outros modos de existência é fictícia. A necessidade de desobedecer essa ordem e atravessar fronteiras para aventurar-me num universo diferente do lugar no qual estou, tem motivado minha prática artística; conhecer outros códigos sociais e deixar-me afetar por eles, pelo prazer de estranhar-me e deslocar-me de meus próprios limites. ${ }^{49}$

\footnotetext{
${ }^{48}$ Texto completo disponível em: http://virginiademedeiros.com.br/obras/sergio-simone/ (último acesso em 27/10/15).

${ }^{49}$ Ibidem.
} 
Foi durante a experiência de criação e documentação de todo esse processo da "Igreja dos Desejos" que a vídeo-instalação para a 31를 Bienal de São Paulo foi criada. A obra Sérgio e Simone \#2foi exibida em uma sala exclusiva para o trabalho, onde eram projetadas três telas simultaneamente, intercalando diferentes momentos do processo de acompanhamento das rotinas de Sérgio e Simone. O que se vê como resultado é uma narrativa na qual as identidades do pastor e da travesti vão convivendo intercaladamente na sala escura de projeção, de uma forma ao mesmo tempo dispare e hibrida, favorecendo uma leitura do trabalho em seus aspectos de interseccionalidades, temporalidades queer e ficcionalidades de gênero.

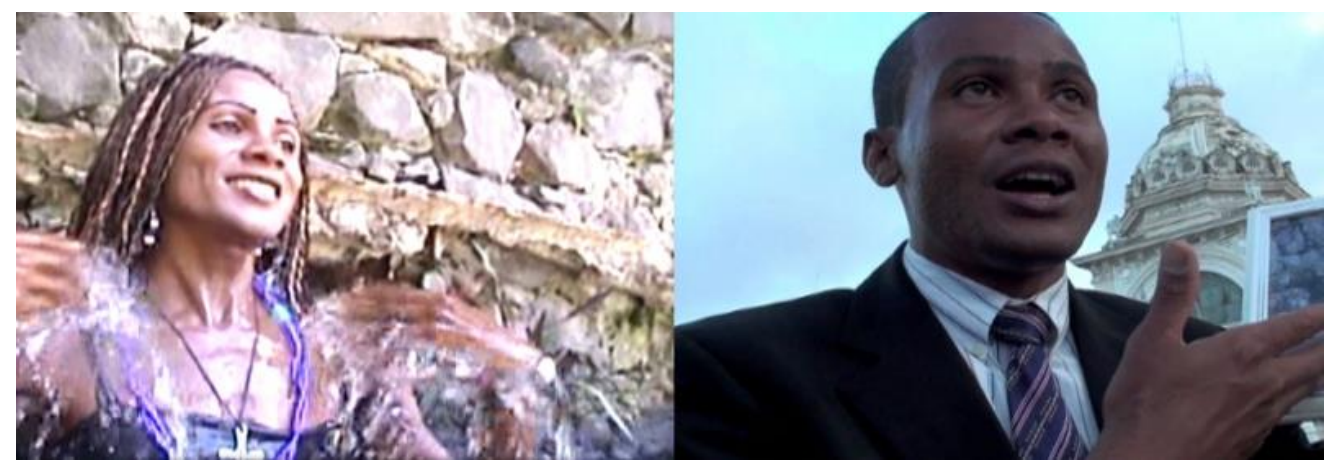

Figura 15 - Frame da obra "Sérgio e Simone", de Virgínia de Medeiros, 2019.

A filósofa pós-estruturalista estadunidense Judith Butler, uma das principais teóricas contemporâneas sobre o feminismo interseccional e teoria queer, pensa que os limites entre os signos referentes ao masculino e ao feminino são criados e estabelecidos no âmbito do discurso. O gênero teria, portanto, em sua base constitucional o aspecto performativo, produzido como resposta às expectativas em relação ao sexo. Citando Nietzsche (1969 p. 45) "Não há 'ser' por trás do fazer, do realizar e do tornar-se; o 'fazedor' é uma mera ficção acrescentada à obra - a obra é tudo" (apud BUTLER, 2015, p. 56), Butler sugere então que o gênero se define a partir da assimilação dos saberes pelo indivíduo, das múltiplas realidades que são apresentadas a ele, da incorporação dessas realidades, das sobreposições desses saberes. Essa assimilação é instável e em permanente movimento, o que constitui o gênero como uma construção e não uma fatalidade. É nesse sentido, que podemos pensar o gênero como performatividade, como aponta o pensamento butleriano. 
Se o gênero é um conjunto de atos repetidos no interior de um quadro regulatório enrijecido por aspectos culturais, sociais e religiosos, a identidade é constituída pelas próprias expressões que supostamente são resultado da assimilação desses códigos. A performatividade é, portanto, um ato que faz surgir o que nomeia e constitui-se na e pela linguagem. Apropriando-se do modelo foucaultiano de inscrição, Butler estabelece toda identidade de gênero como uma forma de paródia produzida nas relações de poder. A lei é incorporada e, como consequência, são produzidos corpos que significam essa lei sobre o corpo e através do corpo. Logo, os gêneros são apenas efeitos de verdade (ROCHA, 2014).

Pensar nas identidades de gênero como aspectos performativos do ser, como sugere Butler, sublinha um dos principais tópicos abordados pela teoria queer como maneira de combater a hétero-cisnormatividade. A performatividade desestabiliza o binário feminino/masculino, que, por sua vez, são entendidos dentro de uma lógica heterossexual, promovendo uma heterossexualidade compulsória, onde os desejos devem ser obrigatoriamente direcionados ao oposto. Assim como as categorias de gênero "homem" e "mulher", se baseiam em oposições e exclusões, que produzem supostas complementaridades, tidas como naturais pelas narrativas hegemônicas, que foram constituídas sistematicamente, no mundo ocidentalizado, com contribuição estrutural das forças religiosas Judaico-cristãs.

Se as teorias queer fornecem subsídios para pensarmos tanto a performatividade do discurso como as performances de gênero, tal como postula Butler, as práticas artísticas contemporâneas de Virgínia de Medeiros e Ventura Profana promovem, cada qual ao seu modo, exemplos de subjetividades dissidentes. Em ambas as pesquisas ressalta-se o aspecto ficcional tanto no âmbito da constituição da sexualidade e do gênero, quanto das narrativas religiosas que impõem o binarismo como uma dinâmica de constituição do ser. A arte, portanto, assume seu caráter provocativo de fabulação de outras realidades. Como afirma Jacques Rancière (2009, p. 58), "o real precisa ser ficcionado para ser pensado".

É evidente a diferença entre as posições das artistas Virgínia de Medeiros e Ventura Profana na elaboração de suas narrativas sobre as questões de gênero, sexualidade, raça e religião - considerando o olhar estrangeiro de Virgínia diante de seus personagens e a produção de Ventura que é ao mesmo tempo vida e obra. No entanto, ambas as pesquisas artísticas podem dialogar, extemporaneamente (e, 
portanto, considerando todas as implicações desse deslocamento), com as abordagens dos filósofos franceses Michel Foucault e Georges Bataille, em suas perspectivas sobre a transgressão, especialmente ao tocarem em aspectos das experiências eróticas e sobre o sagrado.

\title{
3.9. Edificação
}

Em 1954, o pensador francês George Bataille, lançou o livro O Erotismo, frequentemente considerado uma de suas publicações mais importantes. Escritor cuja obra se enquadra tanto nos domínios da Literatura como no campo da Antropologia, Filosofia, Sociologia e História da Arte, Bataille aborda em O Erotismo as relações entre aspectos do erótico e do sagrado, a partir do entendimento de ambos como "experiência interior", desenvolvendo conceitos como o "interdito" e a "transgressão".

Bataille propõe o erotismo como uma tentativa de continuidade naquilo que é descontínuo na vida, através de uma erótica que não se submeta à disciplina ou normatizações. Para isso, ele investiga os interditos ligados, por exemplo, à morte, à reprodução, assim como à transgressão - base para o erótico se colocar dialogicamente com o que é profano (ou dessagrado).

\begin{abstract}
A sociedade humana não é somente o mundo do trabalho. Simultaneamente - ou sucessivamente - ela é composta pelo mundo profano e pelo mundo sagrado, que são as suas formas complementares. O mundo profano é dos interditos. O mundo sagrado abre-se a transgressões limitadas. (BATAILLE, 1954, p.78)
\end{abstract}

As abordagens de Georges Bataille sobre aspectos da transgressão foram retomadas por pensadores pós-estruturalistas, como o também francês Michel Foucault, que dedicou uma publicação inteira acerca das elaborações de seu conterrâneo.

Em Prefácio a Transgressão, artigo publicado em 1963 na revista Critique, ao discorrer sobre a obra de Bataille, Foucault articula o conceito de transgressão como algo que esgarça os limites pré-estabelecidos pelas normatividades, instaurando um novo território instável, labiríntico e movediço, sobre o qual, quase sempre, é impossível delimitar suas fronteiras. A transgressão habitaria, portanto, 
nesse inconstante espaço que chamamos margem. Para Foucault, transgredir é romper com as normas mundanas das vivências e experimentar outras formas de existência, pautadas principalmente pela busca de experiências limítrofes. Esses aspectos são muito presentes no pensamento de Bataille, com seu erotismo sagrado, fortemente influenciado pelo repertório freudiano sobre desejo. Para Foucault, a transgressão consiste justamente no exercício retroalimentado de criação de novas fronteiras:

Logo, a transgressão não está para o limite assim como o preto está para o branco, o proibido para o permitido, o exterior para o interior, o excluído para o espaço protegido da morada. Ela está ligada a ele mais por uma relação em espiral que nenhuma simples infração pode esgotar (FOUCAULT, 2001a, p.265).

Em Foucault, portanto, essa linha de jurisdição da transgressão não é exatamente uma divisa, um limite claro a ser extrapolado, mas antes disso - e sobretudo -, é uma zona de vivências necessariamente marginais, que rompem com as narrativas normatizadas. É nesse sentido, que podemos fazer o exercício de tratar alguns projetos artísticos abordados nesse estudo através de seus aspectos transgressores, especialmente nos trabalhos de Virginia de Medeiros e Ventura Profana, por operarem narrativas de subjetividades dissidentes - ou em trânsito, submetidas à marginalidade e a violência por uma sociedade estruturada pelas normatizações.

Assim como o pensamento de Georges Bataille ofereceu arcabouço teórico para os pós-estruturalistas, se posicionando de forma vanguardista na abordagem de vários interditos ligados ao sagrado e ao erotismo, a produção artística de Ventura Profana amplia o repertório de representações do erótico e do sagrado nas artes visuais, especialmente a partir da temática neopetencostal. Ventura, contudo, se distancia de Bataille por suas abordagens dos interditos não apenas pelo imbricamento (ou fusão) entre o seu discurso, vivência e produto artístico; mas também no destaque de sua condição de mulher trans, preta, latino-americana, e como essas especificidades reverberam em sua relação erótica com os signos sagrados. Nesse sentido, Ventura se desloca da perspectiva universalista da 
epistemologia euro-ocidentalizada e se aproxima das elaborações sobre erotismo propostas tanto pelo feminismo negro da escritora e ativista LGBTQIA+ Audre Lorde, quanto pelas perspectivas eróticas desenvolvidas no âmbito dos estudos das artes por Diana Taylor e Susan Sontag.

A dicotomia entre o espiritual e o político é igualmente falsa, resultante de uma atenção displicente de nosso conhecimento erótico. Porque a ponte que os conecta é formada pelo erótico - o sensual -, aquelas expressões físicas, emocionais e psíquicas do que há de mais profundo e forte e farto dentro de cada uma de nós, a ser compartilhado: as paixões do amor, em seus mais fundos significados. (LORDE, 1984. p. 53-59)

Com sua perspectiva heterológica sobre erotismo, o pensamento de Bataille abre caminho para o da crítica norte-americana Susan Sontag, quando esta afirma que precisamos de uma "erótica da arte" ${ }^{50}$, ou seja, uma experimentação extrahermenêuticano contato com a arte, que priorize o sensível em detrimento da racionalidade. Desta forma, Bataille busca tocar aquilo que escapa à razão, como uma tentativa de romper com o intelectualismo, racionalismo e cognitivismo.

É desse modo que a proposição batailliana se mostra pertinente para apreensão da produção artística contemporânea. Seu elogio da visão contaminada fornece ao olhar uma apreensão mais corporal, indicando, assim, possibilidades artísticas que extrapolam a noção de forma ou de objeto acabado. Esse olhar outro, então, abarcaria uma produção artística mais processual, e mesmo desmaterializada. (PEQUENO, 2014. p. 9)

Esse movimento de Georges Bataille lembra a constituição da experiência estética proposta por Hans Ulrich Gumbrecht (2006). Para Gumbrecht, o conteúdo arrebatador da experiência estética sempre é produzido a partir da relação entre os efeitos de sentido (conceitos) e os efeitos de presença (percepção). E como consequência imediata, a fusão entre o sujeito e o objeto. A ideia de fusão também

\footnotetext{
${ }^{50} \mathrm{Em}$ seu texto Contra a interpretação, Susan Sontag desenvolve ideias propositivas de contraposição à tradição grega de uma leitura mimética da arte, a crítica norte-americana afirma: "Em vez de uma hermenêutica da arte, precisamos de uma erótica da arte." SONTAG, 1987 p.23
} 
aparece na obra de Bataille como direcionamento do erotismo: "O sentido último do erotismo é a fusão" (BATAILLE, 1987, p. 121).

Ao alertar sobre a esterilidade do imperativo pela significação de uma obra de arte, Susan Sontagpropõe, em seu texto-manifesto Contra a interpretação, lançado originalmente em 1966uma dissolução entre forma e conteúdo do objeto artístico. Sendo o conteúdo da obra de arte a parte subjetivada, ou seja, em certa medida inacessível em sua objetividade, é preciso que se destaque a forma, de modo a dessacralizar a interpretação racionalizada de tal experiência e, por consequência, favorecer um contato mais sensível com a arte. De certo modo, há no discurso de Sontag uma busca pela fusão dos processos cognitivos no âmbito da experiência artística, rompendo com a dualidade mimética grega que se estabeleceu como epistemologia hegemônica no ocidente.

A teórica radicada nos Estados Unidos, Diana Taylor, publicou, em 2003, o ensaio $O$ arquivo e o repertório - performance e memória cultural nas Américas, um importante texto no qual apresenta algumas questões acerca dos estudos da performance. A publicação é um recorte de seus estudos na New York University, que tem como foco a investigação sobre as memórias culturais da América Latina. Diana percorre os caminhos da colonização e da formação étnica para compreender os contextos da performance na cultura hemisférica e o lugar dos estudos culturais neste continente. Para isso, a autora trabalha a ideia de desterritorizalização a partir de sua própria vivência. Sendo ela mexicana, com uma educação canadense, a teórica desconstrói o que seria territorializar-se em ambos os lugares de existência. Diana pensa a performance a partir do seu próprio corpo, compartilhando e retratando suas vivências no livro, tecendo críticas sobre a conceitualização restritiva de performance e reforçando o caráter híbrido dos estudos performáticos.

Logo na primeira parte do livro, Diana Taylor introduz os conceitos de performance, apresentando-os, de modo ambivalente, tanto como conceito de análise quanto como uma lente metodológica. Diana observa que a performance é uma forma de gerar e compartilhar conhecimento. Para ela, as performances funcionam "como atos de transferência vitais, transmitindo o conhecimento, a memória e um sentido de identidade social por meio do que Richard Schechner denomina 'comportamento reiterado'” (TAYLOR, 2013, p. 27). Consequentemente, a autora aborda a questão histórica sobre a hegemonia da cultura escrita em relação 
às expressões orais e corporais. Nesse momento, Diana trata dos conceitos de arquivo e repertório, centrais para a proposta dialética do texto.

Para tal elaboração conceitual, Diana Taylor desenvolve algumas questõeschave do livro: a incorporação, ou seja, o papel do corpo na transmissão do conhecimento, e a espacialidade e a temporalidade dos acontecimentos e de suas análises, que influenciam diretamente nas performances.

\begin{abstract}
A tensão entre o que denomino arquivo e repertório tem sido frequentemente construída como existente entre a língua escrita e a falada. $\mathrm{O}$ arquivo inclui textos escritos, mas não se limita a eles. O repertório contém performances verbais canções, orações, discursos -, bem como práticas não verbais. (...) O repertório, seja em termos de expressão verbal ou não verbal, transmite ações incorporadas reais.(TAYLOR, 2013. p. 55)
\end{abstract}

Para a autora, a prática da escrita esteve sempre ligada ao processo de colonização, pelo qual tomava-se posse de um espaço e de um corpo, por intermédio de meios simbólicos, dando legitimidade aos sujeitos que apreendem o método documental da escrita. Os povos das Américas estavam mais ligados aos gestos de incorporação, formas não escritas de comunicação, que localizam sua transmissão especificamente no corpo. Diana desenvolve suas ideias sobre o arquivo e o repertório, ampliando suas localizações no tempo. Assim como o texto arquivado pode se estender temporalmente e transmitir conhecimento, também o repertório, através da incorporação, aparece como veículo difusor de saberes, atravessando passado, presente e futuro. O esforço da autora é para deslocar a performance do lugar de efemeridade - ou "agoridade" - que lhe é frequentemente atribuído.

Ao associar o repertório à incorporação, para então conduzi-lo a um lugar de resistência às práticas colonizadoras na transmissão do conhecimento, a reflexão de Diana Taylor toca no ponto que é importantea este estudo. Georges Bataille e Ventura Profana se relacionam ao elaborarem interseções entre aspectos do sagrado e do erotismo através da transgressão. Enquanto Bataille tem sua produção intelectual circunscrita no âmbito do arquivo e legitimada pelas instâncias canônicas de conhecimento, Ventura trata dos interditos religiosos e eróticos a partir 
de seu repertório de artista mulher transracializada, especialmente através da performance artística.

Esse repertório pode ser associado ao "saber-ruído" elaborado pela artista e ensaísta Jota Mombaça em seu texto Pode um cu mestiço falar? (2015). No ensaio, Mombaça tece uma articulação de conceitos elaborados por pensadoras póscoloniais, como Grada Kilomba e Spivak, denunciando a violência epistêmica experenciada pelos corpos subalternizados no ambiente acadêmico.

Quiçá os saberes-ruído, subalternizados por regimes de verdade instaurados pelo cânone acadêmico-científico, não sejam legíveis como saberes, contudo os deslocamentos de que resultam atravessam infecciosamente as tonalidades do conhecimento, perturbando com estridências sem inscrição a escuta canônica. (MOMBAÇA, 2005)

Recorto esse trecho de Mombaça para destacar a presença dissonante do repertório de Ventura Profana -além de transgredir os já mencionados ambientes das artes e da ortodoxia pentecostal, tambémtransgride a provável circunscrição do contexto de circulação dessa pesquisa acadêmica. Eis, para mim, a pertinência e principal justificativa do protagonismo dado a seu discurso nessa pesquisa de dissertação.O saber-ruído de Ventura, incorporado em sua prática performática, a localiza na mais radical ruptura com a noção colonizadora dos corpos, constituindose como um corpo estranho (ou monstruoso, como sugere Jeffrey Cohen) em todos os ambientes institucionalizados nos quais possa circular: as igrejas, as instituições de arte, as academias científicas, etc.

A obrade Ventura Profana se desenvolve na contraposição de um projeto político de poder religioso hegemônico (que ganha contornos neopentecostais no Brasil contemporâneo), no qual se impõe a padronização das subjetividades e dos corpos em modelos ortodoxos, que repreendema diversidade. Ventura é, portanto, não apenas incorporação dos interditos tratados por Bataille no século $\mathrm{XX}$, mas também a possibilidade de transgressão a partir da transmissão vital de seu repertório contra-hegemônico nos contextos religiosos e das artes.

Em 2017, Ventura Profana lançou uma campanha online de financiamento coletivo para a realização da proposta seminal do projeto Edyficação. O objetivo era construir um templo em Olaria, subúrbio da Zona Norte do Rio de Janeiro, onde na 
época residia a artista, para acolhimento e convivência de corpos dissidentes. $\mathrm{O}$ local seria destinado às pessoas racializadas, dissidentes de gênero e sexualidade, onde os membros poderiam preservar sua segurança e dignidade, desenvolver seus trabalhos e professar a sua fé cristã contra-hegemônica. A campanha virtual não atingiu sua meta de arrecadação de recursos e naquela ocasião o projeto não se concretizou.

Em 2018, Ventura foi selecionada para a residência artística da $7^{\mathrm{a}}$ edição da Bolsa Pampulha. O projeto desenvolvido pela artista em Belo Horizonte foi intitulado Tabernáculo da Edificação e, como sugere o nome, éum desdobramento de Edyficação, ideia elaborada no ano anterior. Se em 2017 o projeto inicial consistia no desenvolvimento de uma campanha de financiamento coletivo pra a construção física de uma igreja, a proposta retomada em Belo Horizonte, desta vez com o aporte financeiro do Museu de Arte da Pampulha, envolveu estudos e redesenhos de mobiliários geralmente encontrados em igrejas (neo)pentecostais. Sobre Tabernáculo da Edificação, Ventura respondeu em entrevista ${ }^{51}$ concedida ao jornal Estado de Minas, em 2019: "Minha obra estabelece uma congregação onde possamos crer na continuidade de nossas vidas, mesmo com a transfobia instituída socialmente como um dos pilares na lei dos homens".

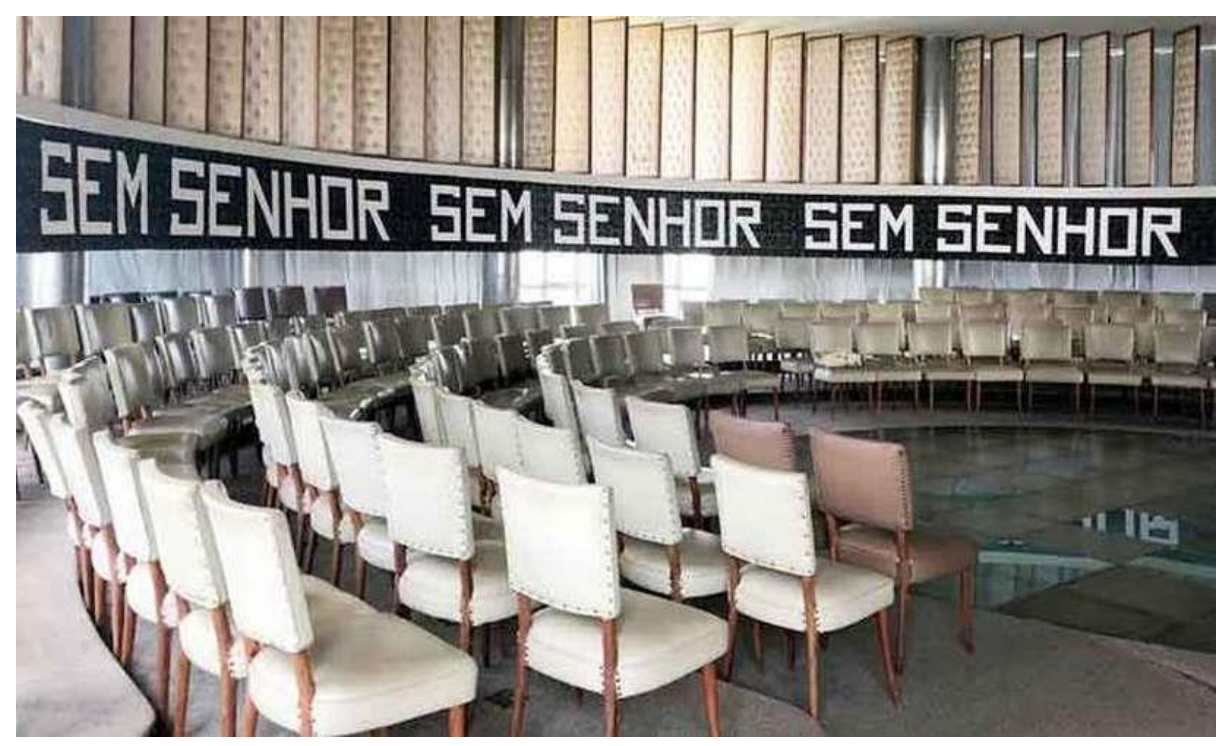

Figura 16 - Obra "Sem senhor", parte do projeto Tabernáculo da Edificação, de Ventura Profana, 2019.

\footnotetext{
${ }^{51}$ https://www.em.com.br/app/noticia/cultura/2019/09/18/interna_cultura,1085909/artistas-da-mostraque-foi-suspensa-no-map-contam-como-sao-suas-obras.shtml
} 
O auditório do MAP foi reconfigurado para receber a palavra da pastora Ventura Profana. Um púlpito de madeira, com a logomarca do projeto Tabernáculo da Edificaçãofoi instalado no palco da grande sala arredondada do prédio modernista. Dentre os mobiliários e adornos elaborados especialmente para intervenção, estão uma faixa de dezesseis metros de comprimento, com os dizeres "sem senhor, sem senhor, sem senhor" pintados de branco sobre fundo preto; além de uma cruz de quase dois metros de altura, feita com madeira e ferro, que reproduzia a ambígua logo do projeto: duas formas semi-elípticas que poderiam ser lidas como duas páginas abertas, duas montanhas, ou uma bunda. No encontro das duas extremidades convexas, uma chama acesa que pode representar o fogo divino que habita as escrituras sagradas, ao mesmo tempo que faz alusão à popular expressão "fogo no cu". A edificação, portanto, como uma chama de desejo profano.

Como parte das ações da Bolsa Pampulha 2018/2019, Ventura Profana propôs a oficina "Trava fantástica, literatura e composição de travesti", com o objetivo de discutir a potência da escrita no vislumbre e demarcação de outras possibilidades de vida. Em dois encontros, ela apresentou trechos de escritos, letras de canções, manifestos produzidos por travestis na última década. "De que maneira as palavras exercem poder sobre a realidade? Literatura de trava é arma de guerra". A oficina contou com leituras e discussões com base em textos de autoras como Jota Mombaça, Linn da Quebrada, Jup do Bairro, Rosa Luz e Monna Brutal.

A finalização do projeto Tabernáculo da Edificaçãose deu em meio à acusação - por parte das artistas participantes da residência - de censura institucional. A performance de Ventura Profana foi inviabilizada, com o fechamento do Museu de Arte da Pampulha, sob alegação oficial da necessidade de reparos estruturais no prédio. Sobre o episódio, Ventura afirmou na entrevista supracitada:

Somos um grupo distante dos padrões impostos e esperados para o perfil de artista. Isso atesta a perda de espaço da branquitude, num dos principais programas de arte do país. Somos protagonistas de nossas próprias histórias, estamos reinventando nossos tempos. É ameaçador para quem visa manter o mundo como está. Está aí, na minha opinião, o principal motivo para a censura. Mulheres trans, negras, indígenas, quilombolas, bichas barranqueiras falando sobre si, sobre nossa ancestralidade, profetizando vida dissidente, homens pretos revisando 0 
histórico de remoções e violências sobre o qual o próprio complexo da Pampulha foi construído. Tudo isso expõe a falsa integridade mineira. Tudo isso dentro de um dos principais monumentos de Niemeyer. O tradicionalismo de Minas Gerais não dá conta de bancar esses passos cruciais para a restituição das nossas vidas, histórias, terras. ${ }^{52}$

“Edi”, na linguagem pajubá ${ }^{33}$ significa ânus (ou cu, popularmente). A Edificação proposta por Ventura sugere uma construção da subjetividade bicha a partir do cu. O ânus está no centro de interesse da libertação dos corpos subalternizados, especialmente no que diz respeito à ruptura com as normatividades hétero-cisgêneras; e também como dispositivo de fala, como atenta Jota Mombaça em seu texto Pode um cu mestiço falar?.

Duas extremidades de um mesmo tubo, o cu e a boca como órgãos interditados revelam a dimensão corpo-política da construção da realidade. Seguindo ainda as pistas de Kilomba, podemos inferir que, como a interdição da boca dos corpos bio-designados negros estava ligada à constituição de um discurso hegemônico não-negro no contexto da escravidão, a interdição do cu nos corpos adequados à norma heterocissexista torna possível a manutenção do gênero como ideal regulatório atrelado à heterossexualidade como regime político. (MOMBAÇA, 2013)

Sendo o ânus esse ponto de encontro das sexualidades dissidentes, a Edyficação propõe um reconhecimento das potencialidades comuns aos corpos, das descobertas e principalmente do fortalecimento dos sujeitos sexuais que não limitam suas subjetividades aos dogmas religiosos. Ou seja, se constituem a partir de uma aceitação do prazer como aspecto positivo e afirmativo da vida.

A temática anal também tem destaque no pensamento de Georges Bataille. Em 1927, Bataille escreveu Ânus Solar, emblemático texto no qual desenvolveu conceitos que partem do seu interesse heterotópico a temas repulsivos às

\footnotetext{
52 Ibidem

${ }^{53}$ Pajubá é um dialeto da linguagem popular constituída da inserção em língua portuguesa de numerosas palavras e expressões provenientes de línguas africanas ocidentais, muito usado pelo chamado povo do santo, praticantes de religiões afro-brasileiras como candomblé, e também pelacomunidade LGBTQIA+.
} 
normatividades. Aparecem em Ânus Solaras expressões "olho pineal" e "Jesúvio", como proposições subversivas às funções pré-estabelecidas dos órgãos relacionados à visão e excreção, correlacionando-os de outros modos. Na obra de Bataille, o anus aparece como ferramenta de visão - ou melhor seria dizer visionária - e não delimitado às funções excretoras de um corpo normatizado.

De importância fundamental para o pensamento batailliano, o elogio do olho proposto não era uma ode ao órgão responsável pela visão óptica, retiniana-científica, oriunda do positivismo do século XIX e do impressionismo. A sua proposição foi a de um olhar outro porque sujo, contaminado, não purista, que não é regido por leis, mas que se forma na inter-relação entre o corpo (ânus e vagina não apenas como orifícios de saída e expulsão de resíduos, mas também de entrada, como maneiras de "ver" e perceber $\mathrm{o}$ mundo) e a consciência (interioridade $\mathrm{e}$ subjetividade). (PEQUENO, 2014, p. 2)

Os pensamentos contidos em Ânus Solar - publicado apenas em 1931, com ilustrações do surrealista André Masson - encontram ressonância nas elaborações de influentes pensadores posteriores a Bataille, como Antonin Artaud, Gilles Deleuze e Félix Guattari, que desenvolvem o já conhecido conceito de "corpo sem órgãos" para tratar justamente da potencialização dos corpos através da desnormatização das funções pré-estabelecidas ao seu funcionamento pleno. Ou seja, novas possibilidades de vitalidades contra-hegemônicas para os corpos. $O$ conceito de "corpo sem órgãos"(CsO) apareceu, primeiramente, na obra de Artaud (1974), e foi reativado por Gilles Deleuze e Félix Guattari (1995; 1996). Resumidamente, trata-se da produção de um corpo mais pleno, mais vivo, mais intenso, um corpo de resistência para o desejo e para a própria vida; o que só é possível se desconstruímos o corpo criado para servir docilmente aos poderes do campo social.

Como vimos, as ideias relacionadas à transgressão pela desestigmatização do cu são articuladas em diversos trabalhos de Ventura Profana. Desde a obraO reino é das bichas, a artista traz para a centralidade de seu discurso o poder de fabulações disruptivas pelo anus. O cu é, afinal, essa ferramenta de enunciações dissidentes quando contraposto à narrativa de imoralidade que lhe foi atribuída através de séculos de normatização dos corpos. Sobre a performance $O$ reino é das 
bichas, o performer e dramaturgo, Anderson Feliciano, escreveu em 2018 o artigo Porta para dentro: o cu como máquina de fabulação:

E sim! O reino é das bichas. Berrava a monstra Ventura. Ao instaurar seu culto ao som poderoso da Jhonatta Vicente aquele espaço-tempo desconstruiu certezas, borrou com seu suor as brancas páginas de nossos conceitos e ainda apontou o cu na nossa cara. Precisaremos agora inventar outras CUlturas que dêem conta de nossos corpos e nossa complexa forma de estarmos no mundo. E elas ainda dançam. Pregam uma nova ordem. Anunciam o Apocalipse. $O$ reino é das bichas. Ao elaborarem uma proposta estética suja, mal acaba, mal alinhada, cheia de vida e falhas, estabelecem outros parâmetros, abrem precedentes para pensarmos outras formas, incendeiam as bases do tradicional culto cristão e anunciam que a deusa delas é uma mulher trans e seus mandamentos elas mesmas inventam. ${ }^{54}$

Em nossa conversa, realizada em 2019, Ventura já destaca a importância do reconhecimento do cu como potência contra-hegemônica e vital em sua obra, e articula a relação da sua presença dissidente com a arte contemporânea e as violências que seu corpo "monstruoso" está submetido.

E aí, na arte contemporânea, a discussão está partindo muito de "que corpo é esse que tá propondo?". Então, primeiro, meu corpo é ponto-chave para isso. Para onde eu quero que essa discussão parta? Para mim, eu quero que parta do meu cu. Que parta do maior tabu. Quero que parta da minha bunda. Para mim, partiu da observação disso, de como meu corpo era recebido pelo mundo, de quem despejava o afeto, de onde vinha o "coió" 55 . Isso tudo faz parte de como eu me relaciono com meu trabalho e minha fé.

Ao elaborar seu enunciado artístico a partir do cu, Ventura Profana se apoia numa ideia política e estética que pensa a potência dos corpos e vozes dissidentes justamente no posicionamento imediato de ruptura (ou, pelo menos, tensionamento)

\footnotetext{
54 http://segundapreta.com/porta-para-o-dentro-o-cu-como-maquina-de-fabulacao/

55“Coió”, na linguagem pajubá, significa violência física, especialmente relacionada aos espancamentos sofridos pela população LGBTQIA+.
} 
com diversos sistemas de repressão. O sagrado para a artista não se relaciona com a repreensão da diversidade. Ao contrário disso, Ventura busca implodir todas as estruturas normativas para que então, desprendidos de limitações, os corpos possam acessar a plenitude de sua potência vital, o prazer, se relacionando assim com a afirmação de vida proposta em sua pregação.

\title{
3.10. O Batismo de Maxwell Alexandre
}

Em julho de 2018, a galeria A Gentil Carioca, localizada no Centro do Rio de Janeiro, inaugurava a exposição $O$ batismo de Maxwell Alexandre. A mostra ficou marcada como a primeira individual do proeminente e jovem artista, nascido na favela da Rocinha, no âmbito de uma galeria de arte. Na ocasião, Maxwell apresentou obras inéditas entre pinturas, instalações e performance, concebidas especialmente para a exposição, que contou com texto crítico do curador Fernando Cocchiarale.

\begin{abstract}
Maxwell distingue, com precisão poética, aquilo que quer dizer discursivamente - Não "pintar negros em situações de mazela e dizimação"; "falar sobre marra, empoderamento e auto-estima" - daquilo que só pode redizer de outras maneiras - por meio da edição de materiais ou de símbolos, em suportes heterogêneos comprometidos com a sintaxe dos trabalhos. (COCCHIARALE, 2018) ${ }^{56}$
\end{abstract}

O título da mostra, intencionalmente performático (COCCHIARALE, 2018), destaca o motivo pelo qual 0 artista carioca aparece nessa pesquisa. Maxwell Alexandre tem incorporado vários elementos da emergente iconografia pentecostal em sua - embora recente - muito profícua obra. $O$ ato batismal na galeria carioca se configurou como um apontamento de que a relação de Maxwell com o circuito da arte seria explorada - e tensionada -, em sua própria pesquisa artística através do uso dialógico (ou metafórico) dos signos do popular sistema religioso evangélico brasileiro,no elitista circuito institucional da arte contemporânea.

Destacava-se na mostra apresentada n'A Gentil Carioca as pinturas em grande formato, técnica e suporte pelos quais Maxwell foi alçado rapidamente ao

\footnotetext{
${ }^{56} \mathrm{https} / / /$ www.premiopipa.com/wp-content/uploads/2019/04/Texto-de-Fernando-Cocchiarale.pdf
} 
posto de expoente nome da nova geração da arte brasileira. As pinturas-mãe, como foram apelidadas pelo próprio artista, são telas pintadas em acrílica, henê, graxa, betume, pastel oleoso e látex. Com frequência aparecem referências de signos e padrões imediatamente associados ao universo das periferias e subúrbios cariocas, como a textura das popularíssimas piscinas Capri. Personagens negros e de cabelos descoloridos se sobrepõem ao fundo azul, aparecendo ao lado de crianças, policiais e pastores evangélicos, em cenas variadas do território onde vive.

As grandes telas de Maxwell retratam uma profusão de cenas do cotidiano da favela onde nasceu e vive, a Rocinha, mas os símbolos contidos em suas obras podem ser facilmente identificados por qualquer sujeito carioca dito periférico. Sendo assim, as representações contidas nas pinturas do artista se configuram como uma espécie de cartografia periférica do Rio de Janeiro, na qual Maxwell aparece como artista-etnógrafo.

O artista, assim, se faz também uma espécie de cartógrafo, mapeando uma nova configuração na qual os moradores da favela, da juventude preta e periférica do Rio, tão romântica e/ou dramaticamente retratados numa certa tradição da pintura e fotografia brasileiras, marcada pela hipersexualização e reencenações de subalternidade, saem da condição de objetos do olhar adventício para o de sujeitos ativos. Autores da própria representação - de si, dos seus e de seu território de pertencimento. (MENEZES, $2020)^{57}$

Os vários símbolos da cultura das favelas aparecem no trabalho de Maxwell convivendo em harmonia caótica, do mesmo modo como coexistem esses elementos no cotidiano desses efervescentes e múltiplos espaços. Contudo, todos os tópicos dispostos na obra de Maxwell parecem orbitar em torno de uma discussão central: a representação negra na arte contemporânea. Quase todos os corpos representados na produção pictórica do artista são de pessoas negras. Frequentemente, Maxwell afirma que todos os personagens pintados por ele são um pouco autobiográficos.

\footnotetext{
${ }^{57}$ https://www.premiopipa.com/2020/10/ocupacao-finalistas-2020-maxwell-alexandre/
} 
A questão da (auto)representação de artistas negros nas artes visuais tem sido um tópico premente e que tem pautado a produção artística contemporânea da última década.

agora são os próprios negros que dão o tom dessa representação, assumindo seus próprios discursos, sendo, simultaneamente, criadores e criação de suas histórias pessoais e de seus antepassados (FELINTO, 2013)

Destaca-se, porém, na produção artística de Maxwell Alexandre um movimento distinto da maior parte dos artistas negros contemporâneos que, comumente, buscam fazer um percurso afro-diaspórico para afirmar as identidades negras subalternizadas pelo processo de colonização. Nesse caminho, os símbolos de uma mitologia religiosa africana ficam em evidência em grande parte das representações sobre negritude nas artes visuais no Brasil. Embora Maxwell assuma o caráter por vezes sincrético de seu trabalho, o que se sublinha na pesquisa do artista carioca é a presença evangélica no contexto das favelas e periferias do país. Assim, destaca-se também o quão negra é a adesão pentecostal, sobretudo nas camadas mais pobres da população brasileira (como vimos na parte inicial dessa pesquisa).

Figura 17 - Recorte de pintura da série "Pardo é papel", de Maxwell Alexandre, $2019 / 2020$.

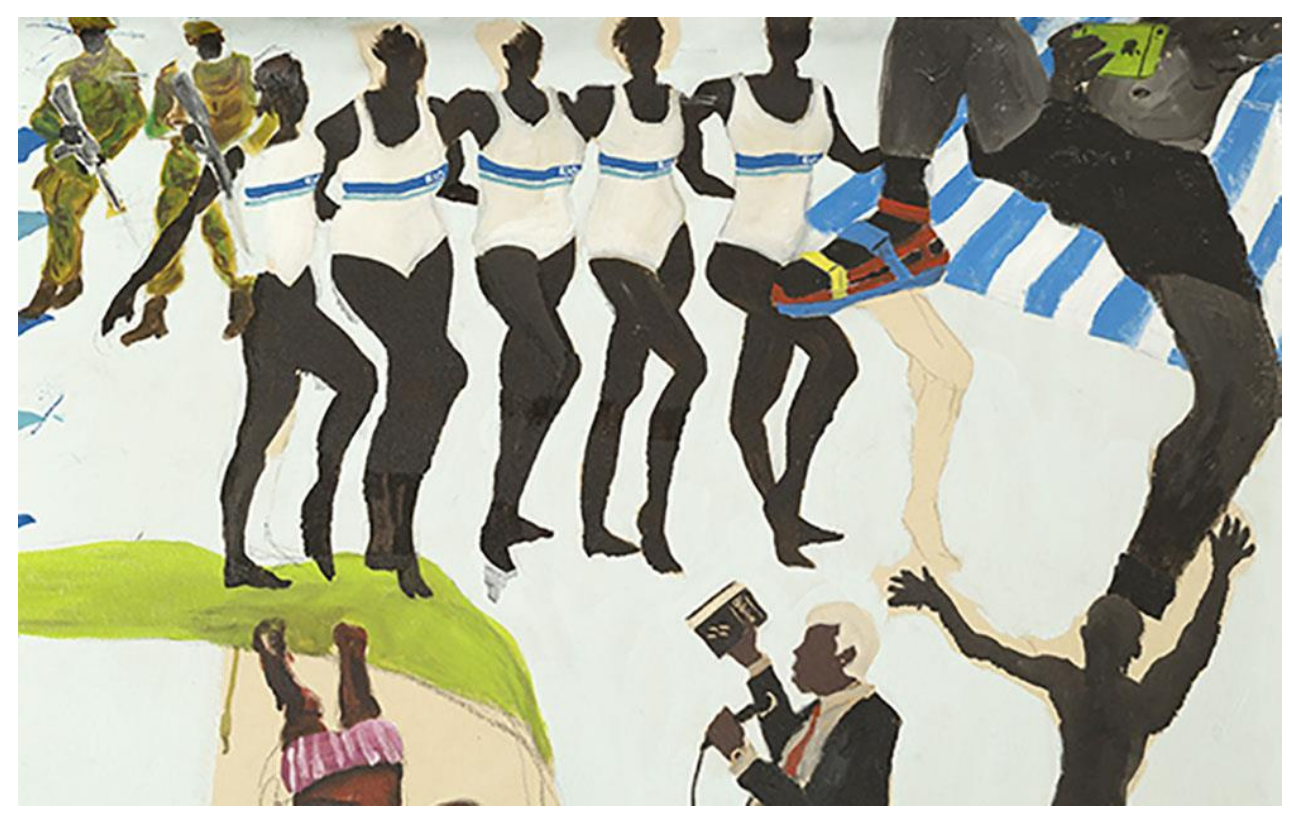


Em meio a representações de agentes das forças militares, piscinas de plástico, Guaravitas, Danones e Toddynhos, aparecem nas telas pintadas por Maxwell Alexandre imagens de batismos evangélicos, pastores empunhando suas bíblias, dentre outros símbolos do universo pentecostal. Essa iconografia evangélica é bastante familiar ao artista carioca. "Fui criado em berço evangélico, minha família inteira é evangélica, com tio pastor. $\mathrm{O}$ acesso à arte e à filosofia foi me ajudando a desconstruir o evangelho" ${ }^{\prime 2}$. As referências religiosas aparecem nas pinturas de Maxwell com a naturalidade de uma relação afetiva.

Quando me vi em artes precisei rever tudo isso que havia escutado e incorporado. Ao desconstruir o evangelho que me ensinou, deixei de usar a linguagem verbal como um meio para me conectar com Deus. Então, encontrei na pintura um caminho legítimo para agradecer, falar e conhecer a mim mesmo. Minhas pinturas são orações, visões e profecias. (ALEXANDRE, 2018) ${ }^{59}$

Chamo atenção ao fato de Maxwell trazer em seu discurso o diálogo com o termo "incorporação"; já articulado nessa pesquisa a partir de um entendimento de Diana Taylor no âmbito dos estudos sobre a performance, e tão pertinente para tratarmos também dos aspectos religiosos elaborados pelo artista. O curador e antropólogo Hélio Menezes destaca a presença dos símbolos evangélicos na produção de Maxwell em um texto publicado no site do Prêmio Pipa, em 2020:

Essa conversão de elementos evangélicos em motes de sua produção responde, antes, a uma movida que toma de empréstimo a linguagem e ritos próprios ao pentecostalismo, segmento cristão de grande penetração nas comunidades da Rocinha e no seio familiar do artista, em franca expansão no mercado religioso de fiéis (e eleitores) no Brasil. (MENEZES, 2020)

Maxwell Alexandre busca se comunicar de modo abrangente, criando um repertório diverso de linguagens, usando uma variedade de suportes, se conectando

\footnotetext{
${ }^{58} \mathrm{https}$ //tab.uol.com.br/noticias/redacao/2019/02/13/fe-arte-e-elite-a-viagem-de-maxwell-da-rocinhapara-o-circuito-europeu.htm

${ }^{59}$ https://revistadesvio.com/2018/07/25/2696/
} 
a cena de artistas negros brasileiros que extrapolam o contexto das artes visuais, como atesta sua aproximação com o meio musical do rap brasileiro (o que veremos mais adiante). Segundo Maxwell, em entrevista ao site Vice Brasil, sua produção é pautada por poetas negros que têm vivências semelhantes à sua. Em depoimento, ele afirma que: "Isso é forte. É uma quebra de paradigmas dentro da história da arte, uma vez que os artistas se alimentam majoritariamente de uma poesia branca e europeia pra produzir" (ALEXANDRE, 2018) ${ }^{60}$.

Pelo destaque de sua produção pictórica, sua rápida ascensão no circuito das artes e o teor político de sua produção, Maxwell Alexandre tem sido frequentemente comparado ao célebre artista Jean-Michel Basquiat. O jovem pintor estadunidense é, por sua vez, um emblemático caso de mudança paradigmática na história da arte, que se conformou com o advento da arte contemporânea e os novos mecanismos institucionais engendrados por ela, capazes de promover o reconhecimento amplo da produção de um jovem artista no contexto institucional.

(...) enquanto um artista moderno, muitas vezes, precisava esperar muito tempo antes de realizar suas primeiras exposições, receber suas primeiras críticas e vender suas primeiras obras, um artista contemporâneo pode experimentar uma ascensão muito rápida na cena artística como no famoso caso de Jean-Michel Basquiat, que teve um sucesso dramático logo depois de seu $20^{\circ}$ aniversário (HEINICH, 2014, p. 383)

Contudo, a figuração não foi a primeira linguagem pictórica adotada pelo artista. Maxwell Alexandre começou a pintar de forma despretensiosa. Entre os $14 \mathrm{e}$ 26 anos, o artista se dedicou à prática de patins, se desenvolvendo na área e tornando-se patinador profissional na categoria inline. Já interessado por práticas artísticas, ele tentou combinar ambas as atividades: desenvolveu uma técnica na qual derramava tinta sobre o chão e, com as rodas dos patins em movimento, pintava linhas abstratas rápidas, de modo que a composição das obras ficava submetida, imprecisamente, às suas manobras e ao relevo irregular dos espaços improvisados onde as telas eram esticadas. Um desses espaços foi o antigo prédio abandonado de um hotel modernista, popularmente chamado de Esqueleto,

\footnotetext{
${ }^{60} \mathrm{https}$ //www.vice.com/pt/article/negayz/conheca-maxwell-alexandre-pintor-inspirado-pelo-rap-e-autorda-capa-do-disco-do-bk
} 
localizado entre os bairros da Gávea e de São Conrado, cujas ruínas o artista frequentou por mais de um ano.

Em 2016, Maxwell Alexandre se graduou, a partir da concessão de uma bolsa integral de estudos, no curso de Design da Pontifícia Universidade Católica do Rio de Janeiro. Na universidade teve seus primeiros contatos com o contexto da arte contemporânea, através do artista visual Eduardo Berliner, professor de Maxwell na graduação. Durante o período em que esteve na universidade, o artista se afastou temporariamente da comunidade onde nasceu e vivia. Após a conclusão dos estudos, voltou a morar na Rocinha, e começou a desenvolver mais efetivamente essa relação com o território em sua produção artística.

Com um novo espaço para trabalhar, ele passou a desenvolver uma nova perspectiva sobre seu trabalho, articulando todas as informações que havia acumulado nesse seu "período de repatriação", resultando em uma nova série de pinturas. Entre os primeiros trabalhos que produziu no novo ateliê está um conjunto de autorretratos em papel pardo, que marcou uma importante virada em direção à figuração. Maxwell logo se deu conta de que a escolha do suporte também acrescentava uma significativa dimensão simbólica ao trabalho. Essa relação simbólica do termo pardo como designação racial e material para suas pinturas acompanharia sua produção artística desde então.

Em 2017, um episódio curioso marcou definitivamente a trajetória profissional de Maxwell. A sucursal carioca da renomada galeria de artes Fortes D’Aloia\& Gabriel, chamada Carpintaria, organizou o projeto chamado Carpintaria Para Todos, uma convocatória aberta para exibição de trabalhos no espaço artístico localizado no bairro do Jardim Botânico, na Zona Sul carioca. O evento foi recebido especialmente por jovens artistas independentes, como uma oportunidade de exibir suas obras em um contexto institucionalizado, possibilitando alguma visibilidade dentro do restrito circuito das artes. Esse, pelo menos, foi o desejo de Maxwell Alexandre.

Maxwell foi um dos primeiros artistas que chegaram e formaram fila na calçada da Carpintaria, antes mesmo das sete da manhã, para conseguir as senhas que foram distribuídas gratuitamente (e limitadamente) aos que buscavam a oportunidade de ter seu trabalho exposto na galeria. Maxwell carregava consigo uma tela em grande formato, estrategicamente enrolada, e sabia que precisava ser um dos primeiros a ter acesso ao espaço expositivo para conseguir alocar 
destacadamente sua obra. A pintura Tão saudável quanto um carinho (2017), que mede $320 \times 476 \mathrm{~cm}$, trazia como tema a controvérsia ocupação das UPPs (Unidades de Polícia Pacificadoras) no contexto das favelas cariocas. Com imagens ao mesmo tempo explicitamente violentas e radicalmente populares, a obra foi apresentada para um grande público de galeristas, curadores e críticos de arte, que passaram então a conhecer a poética e política do trabalho do artista. O esforço deu certo. A grande obra de Maxwell, de fato, se destacou no conjunto de obras amontoadas na galeria. Pessoas influentes, como a atriz Regina Casé, promoveram com entusiasmo nas redes sociais a pintura do jovem artista da Rocinha.

Depois da projeção obtida com a exibição de seu trabalho na galeria Carpintaria, o nome de Maxwell Alexandre ascendeu rapidamente no circuito carioca e brasileiro(e logo adiante, também internacional) das artes visuais. Em menos de um ano após a exposição no Jardim Botânico, Maxwell inaugurava sua primeira exposição individual na galeria que passaria a representá-lo a partir de então. Na supracitada mostra organizada pela A Gentil Carioca, em 2018, além do conjunto de pinturas e instalações produzido pelo artista, o caráter performático da obra de Maxwell também ficou evidenciado.

Um tanque batismal foi instalado na encruzilhada onde está localizada a galeria A Gentil Carioca, no encontro das ruas Luís de Camões e Gonçalves Ledo, no coração do centro comercial popular do Rio de Janeiro, o SAARA ${ }^{61}$. O ponto marcava o final de uma peregrinação artístico-religiosa encenada por Maxwell Alexandre, junto aos artistas Eduardo de Barros e Raoni Azevedo - os três, fundadores do coletivo A Noiva. Os artistas convocaram - através das redes sociais - peregrinos que quisessem se juntar a eles na caminhada de aproximadamente 20 km, entre o ateliê do coletivo na Rocinha, e a galeria no Centro do Rio. Carregaram nos ombros as pinturas-mães enroladas, por quase 4 horas do trajeto feito todo a pé.Todo o ato foi filmado e transmitido em tempo real em telões instalados pela galeria no espaço de exposição.

A performance foi concluída com o batismo de Maxwell Alexandre, reproduzindo o rito pelo qual pessoas recém-convertidas às igrejas evangélicas são mergulhadas por alguma liderança religiosa (nesse caso, os próprios membros do coletivo A Noiva conduziram a cerimônia), como símbolo de comprometimento a uma nova vida santificada pela "água sagrada". No gesto performático, o artista

\footnotetext{
${ }^{61}$ Sigla de "Sociedade de Amigos das Adjacências da Rua da Alfândega".
} 
estava também sugerindo uma consagração de sua chegada ao sistema institucionalizado da arte, o que, de alguma maneira, também significava uma nova vida, com outros códigos e acordos que exigiriam um comprometimento quase que religioso por parte do novo associado à galeria.

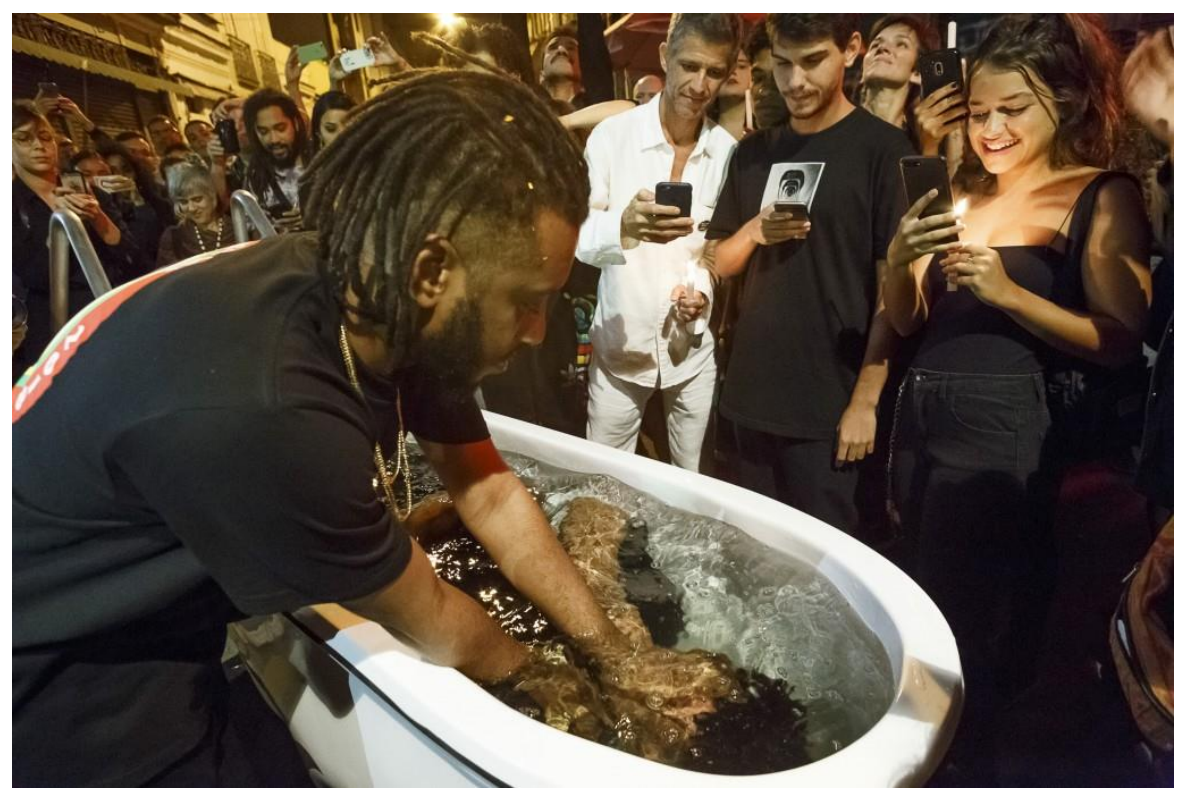

Figura 18 - Registro da performance "O batismo de Maxwell Alexandre", do Coletivo A Noiva, 2018.

A inserção de Maxwell Alexandre no sistema institucionalizado das artes marca, como bem explorou performaticamente o artista, uma nova postura de adesão do mercado e das instituições às pautas emergentes da cultura periférica, com destaque às discussões de raça, gênero e sexualidade, e pré-disposição para a absorção da produção de artistas negros. É nesse contexto, mais fortemente identificado a partir do século XXI, com a maior circulação da produção de artistas periféricos no circuito institucionalizado das artes, que começam a aparecer com mais constância os símbolos evangélicos na arte contemporânea brasileira.

Maxwell, contudo, não está distraído às armadilhas que o rentável mercado liberal das artes engendra ao assumir uma suposta postura inclusiva. Pelo contrário. Seu investimento na pintura, ao mesmo tempo linguagem canônica e segmento mais absorvido pelo mercado, além de destacá-lo como expoente nome da geração de artistas brasileiros com produção circunscrita a partir dos anos 2000, proporciona-Ihe estrutura para, paralelamente, viabilizar suas pesquisas mais 
experimentais. Maxwell sabe exatamente o que significa um jovem artista negro produzindo pinturas no Brasil:

Eu venho da pintura abstrata, tenho uma quantidade imensa de trabalhos antes de começar a pintar Reprovados e Pardo é Papel. Essas duas séries é que me lançaram, pois são sobre a política do corpo negro, entende? E é majoritariamente assim, o espaço do negro é mais certo quando é biográfico e político. Mesmo a arte sendo um dos campos mais canonizados e propícios para falar do sublime, do vazio, do nada, ela nega esse espaço pro negro. ${ }^{62}$

A performance realizada pelo coletivo A Noiva na abertura da exposição $O$ batismo de Maxwell Alexandre deflagra que, ao elaborar um repertório de conexão do circuito das artes com as igrejas evangélicas, o artista se posiciona, estratégica e ambiguamente, de maneira crítica aos dois lados desses repertórios tão díspares de sistemas de poder. Nessa operação de contrastes e semelhanças, Maxwell expõe o abismo estrutural que há entre o contexto de sua vivência na favela da Rocinha e as galerias e museus que passa a frequentar como artista consagrado:

A Noiva se apropria de uma multiplicidade de pontos de referência popular que são alheios ao mundo da arte e das elites culturais, mas que podem atrair o interesse de um grupo demográfico que, por sua vez, sente-se alienado do mundo da arte. Esse "pregar aos não convertidos", nos dois lados do espectro sociocultural - trazendo protocolos evangélicos para o mundo da arte e levando a arte para os protocolos evangélicos -, pode ou não trazer algum tipo de revelação, mas, para além de qualquer efetividade, pode ser compreendido como uma tentativa real de aproximar arte e vida. (MAZZUCHELLI, 2019)

Ainda em 2018, Maxwell Alexandre voltaria a ficar em destaque no circuito nacional das artes. A obra Éramos as cinzas e agora somos o fogo (2017-2018), pintura de escala muralista, que tem seu título inspirado em um verso do rapper carioca BK, foi exposta na parede de abertura da galeria do primeiro andar do Museu de Arte de São Paulo (MASP) no contexto da premiada exposição 'Histórias

\footnotetext{
${ }^{62}$ https://www.vice.com/pt/article/negayz/conheca-maxwell-alexandre-pintor-inspirado-pelo-rap-e-autorda-capa-do-disco-do-bk
} 
afro-atlânticas' ${ }^{\prime 3}$. A grande pintura de Maxwell - que compõe a série em progresso Pardo é papel - se tornou uma espécie de emblema para a histórica mostra que destacava a produção de artistas negros de territórios afro-atlânticos, traçando paralelos, fricções e diálogos entre as culturas visuais dessas regiões. A obra trazia as marcas da assinatura estética já reconhecível de Maxwell, reunindo representações de figuras negras notáveis, como o artista Bispo do Rosário, Basquiat, Nina Simone e James Brown, junto a referências biográficas, universitários pretos diplomados, viaturas capotadas e a onipresente textura das piscinas Capri.

\subsection{A Igreja do Reino da Arte}

Em maio de 2017, quase um ano antes da abertura da sua primeira individual na galeria A Gentil Carioca, Maxwell Alexandre se juntou aos amigos artistas, Eduardo de Barros e Raoni Azevedo para fundar A Igreja do Reino da Arte (IDRA). O coletivo (eles preferem chamar de processo artístico aberto), batizado como A Noiva, surgiu a partir de uma "revelação divina" recebida por Maxwell: "Um dia eu fui dormir e acordei com essa nomenclatura, de um pastor como um curador"64.

Inicialmente, o intuito era criar um espaço (e oportunidades) para exibirem seus trabalhos em mostras e eventos organizados pelo próprio grupo, em resposta às barreiras que artistas periféricos encontram para se inserirem no circuito institucional. "Não queríamos depender de galerias. Não conhecia ninguém do

\footnotetext{
${ }^{63} \mathrm{~A}$ exposição coletiva Histórias afro-atlânticas reuniu, em iniciativa inédita, duas das principais instituições culturais de São Paulo: o Instituto Tomie Ohtake e o MASP. Tratava-se de um desdobramento da exposição Histórias mestiças, realizada em 2014, no Instituto, por Adriano Pedrosa e Lilia Schwarcz, que também assinam a curadoria desta nova mostra, junto com Ayrson Heráclito e Hélio Menezes, curadores convidados, e Tomás Toledo, curador assistente.Histórias afro-atlânticas apresentou cerca de 400 obras de mais de 200 artistas, tanto do acervo do MASP, quanto de coleções brasileiras e internacionais, incluindo desenhos, pinturas, esculturas, filmes, vídeos, instalações e fotografias, além de documentos e publicações, de arte africana, europeia, latino e norte-americana, caribenha, entre outras. A exposição foi articulada em torno de núcleos temáticos. Em cada núcleo, friccionam-se diferentes movimentos artísticos, geografias, temporalidades e materialidades, sem compromisso cronológico, enciclopédico ou mesmo retrospectivo. Histórias afro-atlânticas buscou, assim, oferecer um panorama das múltiplas histórias possíveis acerca das trocas bilaterais - culturais, simbólicas, artísticas, etc. - representadas em imagens vindas da África, da Europa, das Américas.

${ }^{64}$ https://tab.uol.com.br/noticias/redacao/2019/02/13/fe-arte-e-elite-a-viagem-de-maxwell-da-rocinhapara-o-circuito-europeu.htm
} 
circuito; é muito fechado, uma afirmação de privilégio. Achava que nunca ia entrar nessa porra"65, diz Maxwell. Como formato, se espelharam na organicidade das igrejas evangélicas para promoverem um ambiente colaborativo, auto-gestado e empreendedor. À medida que as ações do coletivo iam se materializando, as analogias foram se revelando cada vez mais pertinentes.

Aos poucos, foram sendo incorporadas práticas inspiradas nas liturgias pentecostais, a partir de correlações com os códigos e procedimentos do contexto da arte. Na simbologia da IDRA, as pinturas são chamadas de orações, cultos são as exposições e vernissages, e as caminhadas performáticas (com paradas para cultos à Noiva) são chamadas de peregrinações. Os dízimos são as obras de arte ofertadas para a divindade Altíssima Arte. Há também, esporadicamente, batismos de recém-convertidos, em piscinas de plástico (Capri, é claro) e retiros espirituais/artísticos. Os encontros costumam acontecer no templo da IDRA, localizado na movimentada Travessa Mesopotâmia, na Rocinha. Os membros, quase todos artistas, usam a saudação "Fé na Noiva!" ao se encontrarem ou por troca de mensagens nas redes sociais.

Toda essa operação artística-política do coletivo A Noiva (de criação de um repertório análoga aos rituais evangélicos) é, antes de tudo, um desejo de estabelecer comunicação com um público que, embora reconheça facilmente os códigos religiosos abordados pelo grupo, historicamente não se relaciona com os ambientes da arte contemporânea. Na Igreja do Reino da Arte, rituais e procedimentos, que são bastante próximos às pessoas que talvez nunca tenham tido relação com uma instituição cultural (como parte dos vizinhos do templo localizado na Rocinha), são redirecionados à crença na capacidade da arte em elaborar (novas)formas de significação da vida, por outras vias que não sejam apenas a religião.

Dessa perspectiva, ao propor correlações entre os signos contidos nos âmbitos das artes e aspectos do sagrado, o grupo liderado por Maxwell Alexandre toca em uma vasta e recorrente discussão tanto no contexto da História da Arte, quanto nos estudos filosóficos e das ciências sociais. Enquanto Hegel via a religião substituindo a arte na evolução do Espírito em direção a formas mais altas que culminam no conhecimento filosófico, artistas do fim do século XIX, como Mallarmé

\footnotetext{
$65 \mathrm{https}: / /$ revistatrip.uol.com.br/trip/quatro-apostas-indicadas-por-figuras-consagradas-na-arquiteturaartes-visuais-esporte-e-tecnologia
} 
(1947), Wilde (1994) ou Arnold (1949), viam a arte como instituição - e prática - que tomaria o lugar das funções sociais da religião numa futura sociedade laica. Um pensamento moderno que sugere uma bifurcação no caminho entre essas duas manifestações da subjetividade humana que, nos primórdios, se constituíram sem distinções muito evidentes.

Avaliar a tese de que a arte substitui o papel social da religião na contemporaneidade, demandaria uma investigação densa e dedicada, que não é o foco dessa pesquisa. Torna-se, contudo, cada vez mais evidente ideias que situam a religião como um modelo para descrever a experiência estética e a arte moderna como uma espécie de religião sem Deus. Tais hipóteses são compartilhadas tanto pela teoria da arte (Danto 2003) como pelas ciências sociais, aproximando autores tão díspares como Pierre Bourdieu e Alfred Gell.

Em um texto intitulado Arte e Disturbação, o filósofo e crítico de arte estadunidense Arthur Danto categoriza certas formas de arte como "disturbadoras" (disturbational) por reivindicarem uma espécie de retorno às origens das práticas artísticas, ao contato com o poder mágico, com as forças criadoras e externas ao nosso mundo,

Que cresceram como aglomerados nas bordas do que era tido como os limites da arte: formas de arte que parecem, na superfície, querer retroceder com esses limites, colonizar, por assim dizer, a margem ocidental da vida pela arte (...). É disturbação quando os limites da vida são transpostos de um modo que a mera representação de coisas perturbadoras não pode atingir, exatamente porque elas são representações e reagimos a elas como tais. (DANTO, 2014. p. 157)

Esse tipo de arte que esgarça os limites estabelecidos entre representação e realidade, reconecta-se, de algum modo, com os impulsos humanos primais dos quais se pode acreditar que a arte se originou. O artista "disturbador" não quer mais apenas representar, mas tornar presente ou incorporar algo, recuperando a origem ritualística do fazer artístico. Nesse sentido, ele regressa até mesmo à situação do sacrifício, na medida em que se sacrifica como artista ou sacrifica a própria arte modernamente compreendida, para transformar o público, se o ritual for bem 
sucedido, em participante. Podemos, portanto, atribuir às proposições performativas do coletivo A Noiva o aspecto "disturbador" do conceito elaborado por Danto.

Por outro lado, na visão de pensadores clássicos das ciências sociais, a arte estaria fundamentada numa perspectiva de "fé", ou melhor (ou seria pior?), numa "má-fé" coletiva, que atribuiria valor e sentido a uma produção artística a partir de supostas conveniências. Seria um tipo de "fetichismo", a adoração de artefatos produzidos por humanos, que esquecem o ato de produção para "abduzir" (Gell 2018) poder nesta operação. As teorias de Bourdieu eram particularmente críticas à construção dessa "má-fé" coletiva. Em uma perspectiva pós-moderna, trabalha-se com elaborações "anti-fetichistas" (Latour 2002). Gell, mais radicalmente, assumia que "nós sacralizamos a arte: a arte realmente é nossa religião".

O coletivo A Noiva parece se posicionar na encruzilhada das abordagens "fetichistas" e "antifetichistas" sobre religião e arte, com uma proposição satírica e atualizada sobre os dois temas, sem os disporem em oposição nem em conformidade, mas congregando seus elementos para criar uma mensagem evangelizadora da arte - ou estetizante sobre o sagrado. A abordagem da prática artística como um designo divino, se desdobra dentro da Igreja do Reino da Arte com a metáfora do artista (ou curador, como afirmou Maxwell) como um escolhido por Deus, capaz de dar vazão e compartilhar o seu dom com a comunidade:

Não obstante, o artista considera sua obra como uma resposta adequada a um chamado recebido, um chamado que pode ser intermitente como o chamamento recebido pelo profeta: para ele é uma obra de inspiração, não uma habilidade - embora até mesmo a inspiração não chegue a uma mente despreparada. Ele trabalha sob uma ordenança, o que significa que ele não tem nenhum livre comando sobre a síntese que as coisas recebem de suas mãos. Sua composição é um símbolo do modo geral no qual as coisas o afetam. E este símbolo de um estado de espírito pessoal precisa ser encontrado, não pode ser inventado. (KAUFMANN, 1941)

A analogia do artista como profeta é usual no repertório simbólico do coletivo A Noiva. "Eu sempre tive a noção de ser alguém escolhido. Eu sabia que eu tinha um propósito, e que, se eu optasse por fazê-lo, eu ia fazer bem, ia ter 
reconhecimento e isso ia reverberar no mundo"66, conta Maxwell Alexandre à revista TAB, do site UOL, em 2019. Profeta é justamente o termo pelo qual os líderes da IDRA se chamam. A fala do artista carioca à revista virtual confirma que seu discurso ambíguo não se trata apenas de uma estratégia de comunicação. Há um explícito desejo de ocupação e disputa por um poder hegemônico (o do circuito institucional das artes), recorrendo, para isso, aos códigos e símbolos de um projeto de poder bem sucedido na história recente do Brasil (o crescimento evangélico a partir da adesão popular ao movimento neopentecostal).

Sobre o sincretismo contido nas mensagens elaboradas pela Igreja do Reino da Arte, os fundadores, em entrevista concedida à revista seLect, em 2019, assumem que incorporam referências de outras religiões, tal como fazem algumas igrejas neopentecostais. Mas reforçam o caráter político de se utilizarem de um repertório simbólico do segmento religioso que mais tem crescido no Brasil, especialmente entre as camadas mais populares. Raoni Azevedo afirma sobre o perfil da Igreja do Reino da Arte:

É sincrética. Acho que principalmente no fazer. Mas a gente faz questão de colocar na linha de frente essa questão mais cristã. Nos perguntaram por que não criamos uma igreja de matrizes africanas. Por duas coisas: primeiro porque não é nosso lugar. Segundo que não adianta colocar nesse lugar de embate alguém que está numa posição de resistência. $A$ gente quer usar justamente 0 que está na hegemonia. (AZEVEDO, 2019) ${ }^{67}$

Eduardo de Barros complementa na mesma entrevista: "No campo da arte, as religiões de matriz africana já são bem trabalhadas." Maxwell Alexandre finaliza, posicionando claramente a missão política do projeto artístico: "É porque queremos questionar os poderes desse cristianismo que tá articulando a política, que está no poder das narrativas. Colocar isso no campo da investigação."

Logo o discurso contra-hegemônico começou a cobrar também da Igreja do Reino da Arte uma abertura para a diversidade na formação do seu quadro de participantes. Eduardo, Maxwell e Raoni, três homens cisgêneros e heterossexuais

\footnotetext{
${ }^{66}$ https://tab.uol.com.br/noticias/redacao/2019/02/13/fe-arte-e-elite-a-viagem-de-maxwell-da-rocinhapara-o-circuito-europeu.htm

${ }^{67}$ https://www.select.art.br/entrevista-anoiva/
} 
(perfil majoritário dos membros da lgreja), foram instigados a pensarem em mecanismo que aproximassem mulheres (trans e cisgêneros), e também corpos dissidentes de gênero e sexualidade ao grupo. Esse, pelo menos, foi o motivo que resultou na proposta de realização do primeiro Retiro D’A Noiva (2019), inspirado nos retiros espirituais comuns nas igrejas evangélicas.

Retiro D'ANoiva foi um projeto desenvolvido no âmbito da Igreja do Reino da Arte, que tinha um programa constituído por um eixo conceitual com as seguintes temáticas: rituais de identidade, estruturas de poder e existência periférica. Foi conduzido por artistas residentes, artistas locais, membros da lgreja, colaboradores convidados e a comunidade local. O projeto foi contemplado pelo edital "Periferias e Interiores", realizado pela FUNARTE (Fundação Nacional de Artes), e concedeu "bolsas moradia" aos quatro residentes do Retiro: Dani Câmara (Rio de Janeino RJ), Joca Soares (Niterói -RJ),Yná Kabe Rodríguez (Brasília), e Thayná Rodrigues (Rocinha - RJ). Os residentes foram provocados para conceber, desenvolver e executar juntos, ações que ao final do programa foram apresentadas numa exposição na sede da Igreja d'ANoiva.

Segundo os organizadores, o projeto teve como vetor principal trazer a Rocinha para o centro das reflexões artísticas do encontro, potencializando a observação do território, tanto de seus aspectos físicos como de sua presença ambiental, cultural e política, para a realização de trabalhos. Assim, o grupo buscava expandir discussões sobre práticas artísticas contemporâneas, e especulava também sobre possibilidades de ruptura das fronteiras físicas, a partir da interação com outras áreas da vida social, e a inserção de outros atores da sociedade.

Ao longo do Retiro foram realizadas diversas atividades como encontros com artistas, peregrinações (expedições especiais na Rocinha com o acompanhamento do artista Ducha), encontros gastronômicos, visitas a ateliês, entre outros. Todas as atividades foram realizadas de forma gratuita, sendo apenas algumas delas abertas ao público, tais como: conversas com artistas e pesquisadores, rodas de leitura, sessões de filmes de artista, o "Tela Crente" com Rodrigo D’Alcântara e Virgínia de Medeiros (artista já citada nessa pesquisa).

Para as atividades da programação foram convidados: Agrippina Roma Manhattan, Aleta Valente, Ana Luiza Fonseca, Bruno Balthazar, Carlinhos Roberto Araújo, Cildo Meireles, Clarissa Diniz, Cozinha Transada, Ducha, Emílio Domingos, 
Felipe Ferreira de Almeida, Franz Manata, Frozen 2000, Joji Cozzolino, Henrique Vieira, Laura Lima, Marcia Fortes, Marcio Botner, Paulo Paes, Rafael Bqueer, Rodrigo D'Alcântara, Ronald Duarte, Saulo Laudares, Slam das Minas, Ulisses Carrilho, Virgínia de Medeiros e Vivian Caccuri.

O artista Raoni Azevedo, na supracitada entrevista à revista seLect, toca em um ponto estruturante sobre o qual essa pesquisa está sendo desenvolvida: o aspecto ficcional (ou as fabulações) nas narrativas sobre o sagrado - e também sobre arte, de maneira geral.

A gente tende a perceber as instituições como coisas consolidadas e dadas e que foram criadas por uma coisa que você não tem controle ou que é maior do que o indivíduo. Mas qualquer indivíduo pode criar uma igreja, pode declarar um partido político e fazer ele existir de várias formas. É tudo ficção. A Jota Mombaça fala algo assim, é tudo ficção, a constituição é uma ficção. São coisas que não existem de fato, foram criadas enquanto narrativas. Uma forma das pessoas se unirem é acreditarem nessas fiç̧ões. $^{68}$

A fala de Raoni conecta a intencionalidade do coletivo $A$ Noiva às abordagens de outros artistas já destacados nesse texto. A fabulação aparece, portanto, como método e ferramenta de disputa de poder que emergem, tanto no campo das artes visuais quanto nos segmentos religiosos. A ficcionalidade torna-se então uma perspectiva pela qual se deseja disseminar outras verdades. Nesse sentido, Igreja do Reino da Arte, em sua devoção à Altíssima Arte, não propõe a substituição de uma visão hegemônica por outra narrativa cristalizadora. Antes disso, o coletivo produz uma poderosa e ambivalente crítica ao colocar um espelho diante das instituições artísticas, frequentemente consideradas progressistas diante do contexto predominantemente conservador de outros setores da sociedade, e expõe o quanto há de reacionário e excludente no projeto anti-popular desempenhado historicamente pelo circuito das artes. Revela-se, assim, mais semelhanças do que diferenças entre os dois ambientes, supostamente dispostos a uma distância abismal.

\footnotetext{
${ }^{68}$ Ibidem.
} 


\subsection{Traquejos pentecostais para matar o senhor}

O dia 1 de abril de 2020 marcou o lançamento do álbum O anjo Maxwell, terceiro projeto musical d'A Noiva e quarto dízimo do artista Maxwell Alexandre. Os três álbuns lançados pelo coletivo têm um caráter experimental, com uma estética bastante associada ao universo hip hop e ao rap (tão influentes no trabalho pictórico de Maxwell), cheio de samplers (bases sonoras pré-existentes), vinhetas, feito artesanalmente, com gravações precárias. A temática segue a analogia central da proposta artística do grupo. As músicas foram batizadas com títulos como: "Qual é a sua obra?", "O templo da arte", "Conversa entre artista e curador", "Oração", "A noiva chegou", "Pinturas são orações", entre outras referências que mesclam expressões do contexto religioso evangélico e o ambiente da arte contemporânea.

Para Maxwell, "A obra $O$ anjo Maxwell é um álbum para edificar fé de artista"69. O projeto musical compõe a camada mais experimental da obra do artista, em associação com os membros da lgreja do Reino da Arte.

Como artista, penso que é poderoso buscar outras mídias para me manifestar, inclusive alimentar e complementar minhas outras práticas. Então, o álbum acaba sendo uma peça interessante para entender toda essa mitologia que eu venho criando. É mais uma parte do meu evangelho. ${ }^{70}$

A música tem sido uma potente ferramenta de evangelização no Brasil, se consolidando como uma das principais expressões artísticas praticadas no âmbito das igrejas evangélicas, considerando seus mais diversos segmentos. $O$ desenvolvimento dos ministérios de louvor, grupos formados por membros das congregações com maior aptidão para a performance musical, promoveu a criação de um mercado fonográfico gospel no Brasil que já há algum tempo compete em igualdade com o segmento secular, seja em aspectos de abrangência, seja em rentabilidade.

A visibilidade que a música gospel brasileira adquiriu na indústria fonográfica a partir da primeira década do século XXI, foi tão significativa que alguns estudiosos

\footnotetext{
${ }^{69}$ https://dasartes.com.br/materias/maxwell-alexandre/

${ }^{70}$ Ibidem.
} 
chamaram o fenômeno de "explosão gospel". Para Magali do Nascimento Cunha (2007), a "explosão gospel" iniciada nos anos 1990 no Brasil não corresponderia apenas a um segmento musical, mas assumiria a forma de uma "cultura gospel"71, que seria um novo modo de ser dos evangélicos brasileiros. Essa nova manifestação cultural seria constituída de forma híbrida, misturando aspectos da tradição e da modernidade. A tradição corresponderia à manutenção da doutrina protestante, tal como se desenvolveu no Brasil no início do século XX, caracterizada pelo individualismo, antiintelectualismo, antiecumenismo, exclusivismo religioso, sectarismo, demonização das culturas brasileiras tradicionais e também do catolicismo popular, além da manutenção de uma abordagem binária sobre Igreja/mundo e sagrado/profano. Já o aspecto moderno se traduziria em novas formas de culto, de expressão verbal, visual e de comportamento, inseridos na lógica do espetáculo, do entretenimento e do consumo. Por trás dessa cultura estariam a Teologia da Prosperidade e a Guerra Espiritual, cujo sucesso poderia ser explicado por sua associação a fatores socioeconômicos e políticos: o neoliberalismo, que promoveria a crença na inclusão social individual e na importância da autoestima em uma sociedade que não resolve o problema da exclusão social.

É essa cultura gospel emergente que permeia um dos projetos mais recentes da artista Ventura Profana. Como vimos na seção biográfica da artista nesta pesquisa, Ventura se relaciona com a música evangélica desde a adolescência, quando participava do ministério de louvor da igreja que frequentava em Olaria, no Rio de Janeiro. Os hinos evangélicos fazem parte de um repertório afetivo e ainda de consumo da artista. Esse contato influencia sua produção artística desde os primeiros trabalhos. Mas foi apenas em julho de 2020 que Ventura lançou seu primeiro álbum musical, produzido por PODESERDESLIGADO.

Oálbum TraquejosPentecostais para Matar o Senhorfoi precedido pelo lançamento do clipe Resplandescente ${ }^{72}$, uma das seis faixas do projeto da dupla Ventura Profana e Jhonata Vicente (PODESERDESLIGADO). O vídeo de

\footnotetext{
${ }^{71}$ Se a "cultura gospel" a princípio foi utilizada para se referir aos evangélicos pentecostais e neopentecostais, hoje vemos análises que estendem o termo para o catolicismo. Na visão de Branda Carranza, a Jornada Mundial da Juventude de 2013, no Rio de Janeiro, teria consolidado a "cultura gospel católica", processo que teria iniciado nos anos 1990 com a formação do que a autora chama de "pentecostalismo católico". Ver entrevista da autora na revista IHU Online, publicada no dia 31/07/2013. Disponível em: https://goo.gl/cv4Fd7.
}

${ }^{72} \mathrm{https}: / /$ www.youtube.com/watch?v=vUTLYimT6n8 
Resplandecente foi lançado ainda em 2019, como parte da instalação Tabernáculo da Edificação, no Museu de Arte da Pampulha. A obra foi produzida com a colaboração das artistas Rainha Favelada, Carlos Queiroz, Vedroso, Davi de Jesus do Nascimento e Guerreiro do Divino Amor. Na letra do hino composto por Ventura, a pastora travesti profetiza sua iconoclastia anti-colonial: "Travesti no comando da nação / E nós, juntas rogamos a praga / Que o macho caia / e o seu Deus transicione". As imagens do videoclipe foram captadas em Pirapora, município interiorano de Minas Gerais, tendo o rio São Francisco como principal locação. Em março de 2021 a obra audiovisual já ultrapassava 55.000 visualizações no YouTube.

Em release compartilhado sobre o álbum Traquejos Pentecostais para Matar o Senhor, Ventura e Jhonata Vicente sentenciam:

Benzedura. Conduzidas nas águas profundas espirituais, banhamo-nos em fé com canções que preparem: em tempero, armadura e poder, nossas almas corpos terra para a guerra. Contra o domínio cruel e colonial dos senhores, que por séculos, nos escarnece e mata. Com cantigas proféticas, de vitória e encantaria freamos o plano necropolítico e alvejante de condenação do devorador. Desembainhamos espadas flamejantes e com exatidão acertamos a flechada na cabeça do inimigo. Talhamos a letra-morta-de-morte até que ela possa se tornar novamente vida. TRAQUEJOS PENTECOSTAIS PARA MATAR O SENHOR, é fruto da junção benta dos louvores ministrações de VENTURA PROFANA ao toque batida saturado de shofar e tambor de PODESERDESLIGADO, que invocam fôlego para ressuscitar e ensejo de restituição, na congregação preta, trans travesti, originária. $^{73}$

Com o álbum, Ventura Profana se projeta, ainda que em uma escala mais recortada, dentre um grupo de artistas dissidentes de gênero e sexualidade, inseridas no contexto da música pop brasileira, que incorporam o repertório semântico e estético evangélico em suas produções. Em novembro de 2019, a compositora, cantora e atriz Linn da Quebrada lançou o videoclipe da música Oração, composta pela própria artista. Linn tem sido apontada como uma das mais expressivas artistas da nova geração da música brasileira, aliando sua produção ao

\footnotetext{
${ }^{73}$ https://podeserdesligado.bandcamp.com/album/traquejos-petencostais-para-matar-o-senhor
} 
ativismo social pelos direitos civis da comunidade LGBTQIA+ e da população negra. Linn inovou ao deslocar do estereótipo de travesti, assumindo sua transexualidade apenas modificando sua identidade de gênero, sem realizar transição hormonal. Seu reconhecimento se deu através de sua abordagem mordaz e estilo sarcástico bem particulares, tocando em tabus e desconstruindo noções hegemônicas de gênero, sexualidade e raça.Participa da obra audiovisual Oração um grupo de mulheres transexuais e travestis, dentre as quais está Ventura Profana.

Pabllo Vittar, um dos nomes mais influentes da música pop brasileira contemporânea, lançou em 2020 seu 3ํólbum de estúdio, intitulado 111. Dentre as canções está Rajadão, uma música pop eletrônica influenciada pelas recorrentes metáforas, usada pelo léxico pentecostal, que associa fenômenos naturais à manifestação do poder divino (como terremoto santo). "A previsão do tempo diz que o céu fechou / o poder da vitória vai curar a dor / o temporal agora vai cair em mim / a chuva da vitória vai chegar no fim", diz a letra. Em março de 2021, Rajadãoj á havia se tornado a segunda música mais ouvida da cantora, ficando atrás apenas do hit Amor de Que. A canção acumula mais de 8 milhões de reproduções na plataforma Spotify. A dragqueen, que refuta rótulos e sentenças sobre sua identidade de gênero e sexualidade, vem acumulando conquistas na carreira.

Embora essas referências musicais estejam fora do foco das linguagens artísticas contidas nesse estudo, considero importante situar o lugar de visibilidade em que a artista multimídia Ventura Profana está localizada. E, ao fazê-lo, acabo por destacar também, em quais mídias e suportes os símbolos evangélicos aparecem em produções artísticas de larga escala, em um contexto mais popular, que extravasa o ambiente religioso no qual surgem esses códigos e manifestações. Mais uma vez, Ventura Profana se sobressai em relação às outras artistas musicais aqui mencionadas, por sua produção que não apenas se utiliza dos símbolos evangélicos como uma apropriação para realização de um produto mercadológico secular. As canções compostas por Ventura são, acima de tudo, manifestos que dialogam com o repertório evangélico, no sentido da tomada de posição da pastora travesti também como cantora gospel.

\subsection{Plantações de traveco}


De novembro de 2020 a março de 2021, o CCSP (Centro Cultural São Paulo), instituição localizada no centro da capital paulista, realizoua $30^{\circ}$ edição do seu programa anual de exposições. A Mostra do Programa de Exposições do CCSP, em 2020, comemorou três décadas de realização ininterrupta do programa, resultado de chamadas públicas que Ihe dão forma desde 1990. A trigésima versão da mostra marca também uma inflexão importante no curso do Programa, com a presença majoritária de artistas não brancos e de origens regionais diversas, "expressão inequívoca da mudança de cenário que as artes contemporâneas têm passado em anos recentes no Brasil, a partir de formas, linguagens e pesquisas artísticas mais plurais", segundo release apresentado no catálogo oficial ${ }^{74}$.

A programação da $30^{a}$ Mostra CCSP foi composta por um conjunto 4 exposições de artistas convidados pela curadoria do Centro Cultural e 14 exposições individuais de projetos selecionados através de edital público (que, em 2020, bateu recorde com 874 inscrições). A quantidade expressiva de artistas, interessados em exibir seus trabalhos no espaço cultural, provenientes de todas as regiões do país, destaca e localiza o CCSP como importante projeto de articulação e visibilização da produção mais emergente da arte contemporânea no Brasil. As obras que compõem as 18 exposições apresentadas na Mostra ocuparam de forma orgânica todo o prédio situado na movimentada Av. Vergueiro. Os trabalhos foram dispostos extrapolando as galerias e espaços expositivos, povoando a fachada, os corredores, terraço e o entorno do CCSP.

Sob curadoria de Hélio Menezes, a Mostra CCSP, inaugurada no final de 2020, foi marcada pelo macro-contexto - restritivo e trágico - da maior crise sanitária e o mais grave colapso ${ }^{75}$ hospitalar da história do Brasil: a pandemia causada pela propagação do novo coronavírus. Em março de 2021, o Brasil já registrava mais de 260 mil mortes causadas pela Covid-19, doença manifestada através da infecção do novo vírus. Tamanha calamidade, obviamente, impactou todo o setor cultural e a produção artística, não apenas no Brasil, mas também em diversos países do mundo. Menezes, que é antropólogo de formação, buscou articular na curadoria da Mostra esses aspectos urgentes das incertezas e morbidade contidas nesses tempos pandêmicos:

\footnotetext{
${ }^{74}$ http://centrocultural.sp.gov.br/wp-content/uploads/2020/12/ebook_catalogo_mostra2020_online.pdf

${ }^{75} \mathrm{https}$ ://portal.fiocruz.br/noticia/observatorio-covid-19-aponta-maior-colapso-sanitario-e-hospitalar-dahistoria-do-brasil
} 
Neste ano marcado por enfermidades (as do conservadorismo moral, ainda maiores que as do corpo), pela emergência da finitude, o fim do mundo nunca foi tão debatido, temido, planejado, vivido, adiado, e mesmo desejado - o fim deste mundo, tal como o conhecemos, ao menos. Eis a força inspiradora dos termos propostos pela Poética Negra Feminista de Denise Ferreira da Silva: uma rotação tal no pensamento que se dá encargo de findar o Mundo Ordenado, apreendido pela ficção do Sujeito, que dê fim à dívida impagável. "O que está em disputa?", questiona a autora, numa reflexão extensível às perguntas que uma prática curatorial antidisciplinar, quero crer, deve também e continuamente fazer-se no contemporâneo, se se quiser relevante: "O que precisará ser renunciado para conseguirmos libertar a capacidade criativa radical da imaginação para dela obtermos o que for necessário para a tarefa de pensar o Mundo outramente? Nada menos que uma mudança radical no modo como abordamos matéria e forma".

Nesse contexto de fabulações sobre o fim do mundo - e, também, de invenções de outras possibilidades de existir -, Ventura Profana ergueu sua Plantações de Traveco, para a Eternidade, primeira exposição individual da artista. Convidada para compor a 30 Mostra CCSP pelo curador Hélio Menezes, Ventura apresentou uma panorâmica de sua mais recente produção artística, incluindo obras inéditas. Foram exibidas algumas obras da sua pesquisa Tabernáculo da Edificação, com seus redesenhos de mobiliários de igreja pentecostais, e também a gigante bandeira camuflada de 16 metros, batizada de Sem Senhor. O manifesto insubmisso da bandeira hasteada por Ventura dialoga conceitualmente com a proposta indisciplinar da mostra curada por Hélio Menezes.

A obra afirmativa de vida elaborada por Ventura Profana adquire novas nuances diante do acirramento da necropolítica (MBEMBE, 2011) manifestada de forma latente com a pandemia do novo coronavírus. Segundo estudos ${ }^{76}$, pessoas negras são as que mais morrem pela Covid-19 no Brasil, sendo também o grupo de maior incidência de contágio pela doença. Em 2020, mesmo em meio à crise sanitária pandêmica, o Brasil foi o país que mais teve casos de assassinato de

\footnotetext{
${ }^{76} \mathrm{https}: / /$ www.abrasco.org.br/site/noticias/desigualdade-racial-por-que-negros-morrem-mais-quebrancos-na-pandemia/49455/
} 
pessoas trans em todo o mundo $^{77}$, superando o seu próprio recorde de anos anteriores.

“Eu não vou morrer!", reafirma Ventura, à mórbida condenação viral/colonial, em um dos trabalhos exibidos na mostra em cartaz no CCSP. Em um texto crítico elaborado especialmente para a exposição Plantações de Traveco, para a Eternidade, x pesquisadorx e artista visual Linga Acácia destaca a abordagem contra o aniquilamento a que os corpos dissidentes e racializados são submetidos pelo processo colonial:

Ventura trama um plano para adiar o fim, cria possibilidades para transmutar nossos corpos $e$ fortalece uma cosmopercepção que vem sendo construída de forma transcestral, na qual podemos expandir a noção sobre nós mesmas e delimitar aquilo que teima em nos circunscrever de forma fóbica. Ao operar esse acolhimento e fazer dessa terra um lugar vivível, cria-se interrupção, fendas, feridas nessas operações de aniquilamento que marginalizam vivências trans e racializadas. (ACÁCIA, 2021)

Destaca-se na primeira exposição individual de Ventura Profana a construção, com tijolos aparentes, erguida por mãos de travestis e transexuais (através de um mutirão convocado pela própria artista), que constitui uma grande instalação artística no coração do espaço expositivo do CCSP. A obra Nem Eu Nem Minha Casa Servimos Ao Senhor (2020) é a concretização da congregação idealizada por Ventura desde suas primeiras elaborações artísticas. As paredes da igreja da pastora travesti se erguem e se sustentam pela comunhão e compromisso dos corpos dissidentes com uma perspectiva afirmativa de vida. Um abrigo ainda mais simbólico no contexto pandêmico.

A existência travesti negra é a própria travessia, cada corpo como testemunho da religação à diversas narrativas que atravessam a história, se encontram em uma trama. A plantação se faz na congregação - trabalho de mutirão, singular e coletivo. "Nem Eu Nem Minha Casa Servimos Ao Senhor" (2020), uma arquitetura feita por meio de esquemas

\footnotetext{
77 Os dados são do dossiê "Assassinatos e Violência contra Travestis e Transexuais Brasileiras em 2020" da Associação Nacional de Travestis e Transexuais do Brasil (ANTRA). Disponível em: https://antrabrasil.files.wordpress.com/2021/01/dossie-trans-2021-29jan2021.pdf
} 
e engenharias próprias. Preparar o tijolo e o cimento. Os baldrames estão a postos e, ali, todo um processo de criar fundações, relembrar a nossa força de construir um mundo, edificar nosso pensamento em bases sólidas e flexíveis como uma raiz que se firma sobre as ruínas de um monumento erguido em pactos falidos. (ACÁCIA, 2021)

Uma coletânea da produção artística de Ventura Profana dos últimos cinco anos ambienta o templo construído na exposição Plantações de Traveco, para Eternidade. "As que confiam na Travesti são como montes de Sião", está escrito em uma das paredes externas que compõem a igreja-instalação. As palavras pintadas em spray de cor preta, fazem referência à passagem bíblica do livro de Salmos, no capítulo 125, versículo 1, que diz: "Os que confiam no Senhor serão como o monte de Sião, que não se abala, mas permanece para sempre". Refutando a funesta presença do senhor colonial, Ventura Profana clama pela restituição de vida aos corpos dissidentes, utilizando a arte contemporânea como ferramenta de combate à política senhorial. Para isso conclama outros corpos subalternizados:

\begin{abstract}
'Estamos reunidas, conjurando a nossa vida eterna. Hoje, a gente tem disputado a nossa presença na eternidade, eu disputo a eternidade. É por isso que a gente está dentro da arte contemporânea, a gente está disputando as narrativas do futuro, a gente está disputando outras possibilidades, outras semióticas, outras imagens, outras narrativas de vitória. A gente está disputando a ocupação dessas terras futuras. (PROFANA, 2020) ${ }^{78}$
\end{abstract}

Com a exposição Plantações de Traveco, para Eternidade, Ventura explora o binômio construção/destruição na perspectiva da criação de um novo mundo, pósapocalíptico, pós-colonial, se alinhando aos tópicos das abordagens contemporâneas dos estudos descoloniais, ou decoloniais. A destruição desse mundo moderno, patriarcal, misógino, hétero-cisnormativo, binário e racista, demanda fabulações sobre um outro território de vivências, mais plural, menos normatizado. É com a arte que Ventura Profana responde a esse chamado divino por restituição de vida, o fim da dívida impagável descrita por Denise Ferreira da Silva. No livro homônimo escrito por Denise, a ensaísta e artista visual Jota Mombaça e a pesquisadora e performer Musa Michelle Mattiuzzi apresentam um

\footnotetext{
${ }^{78} \mathrm{https}: / /$ subtile.co/perform/ventura-profana
} 
prefácio através do texto performático Carta à leitora preta do fim dos tempos, onde articulam ideias e conceitos anticoloniais para implosão do mundo moderno a partir das fabulações negras.

(...) 050. Como descolonizar a matéria?

002. A destruição como experimento de um processo anticolonial; a destruição do mundo que conhecemos como possibilidade de imaginação política.

531. O Plenum se precipita pelas brechas do mundo como conhecemos. A pretitude é uma brecha. Uma brecha é um portal e todo portal depende de um campo de força. Se a modernidade é um regime de constrição telepática, a performance preta (criadora de portais e campos de força) é uma rebelião contra esse limite.

303. Destruição como performance generativa de uma leitura abolicionista para o mundo. (...) (MATTIUIZZI; MOMBAÇA, 2019)

A exposição Plantações de Traveco, para Eternidade, ao apresentar uma visão panorâmica da pesquisa artística de Ventura Profana, localiza seu discurso no âmbito das temáticas pós-coloniais, que marcam a perspectiva crítica a modernidade que constitui - especialmente - o mundo ocidentalizado tal como conhecemos. Por sua produção focada na vivência de corpos marginalizados no Brasil, Ventura se aproxima ainda mais da abordagem decolonial, proposta por pensadores latino-americanos. 


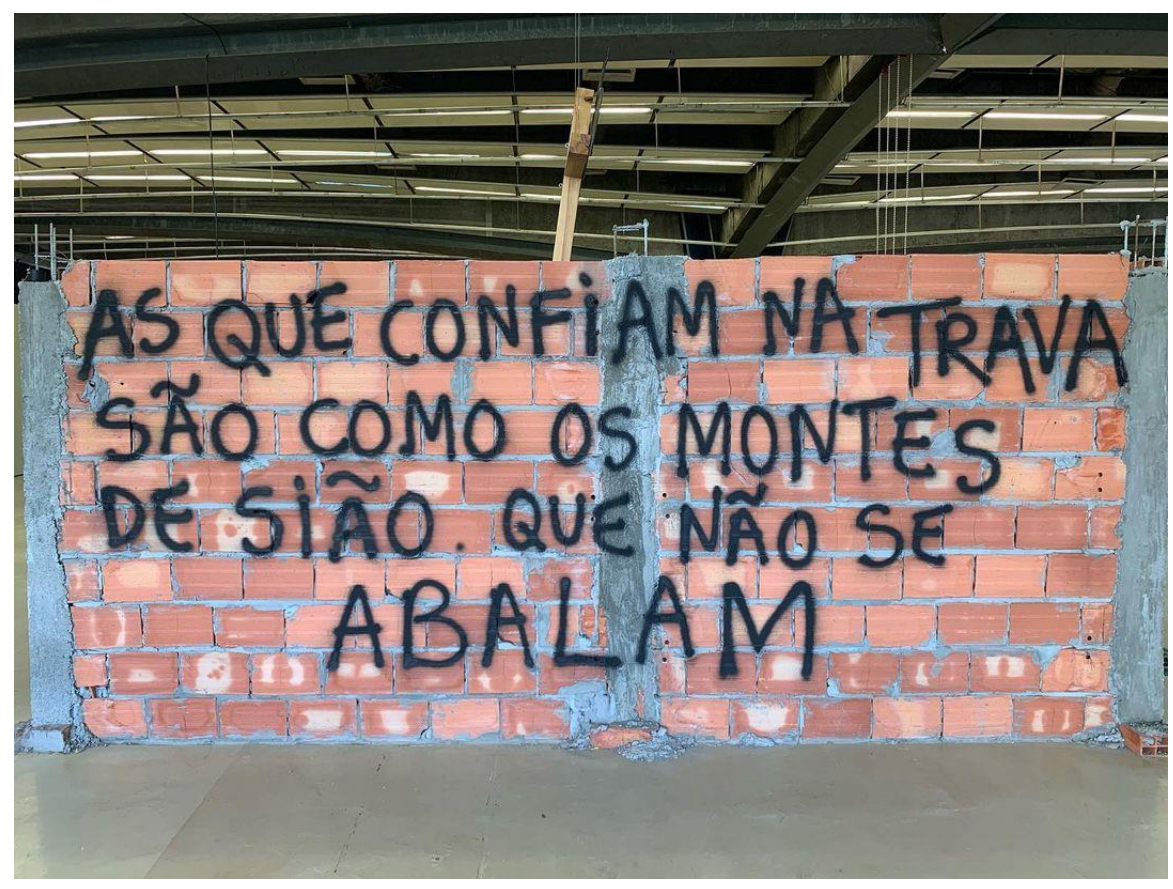

Figura 19 - Parte da exposição "Plantações de Traveco, Para Eternidade" individual de Ventura Profana, em cartaz no Centro Cultural São Paulo, 2020/2021.

Embora essa pesquisa não se aprofunde nas elaborações acerca da decolonialidade (tema abrangente e cheio de nuances, que mereceria uma atenção especial em sua abordagem), se faz necessário entendermos o conceito, estruturado e disseminado, principalmente pelos teóricos Walter Mignolo (argentino), Edgardo Lander (venezuelano), Arthuro Escobar (colombiano), Enrique Dussel (argentino), Fernando Coronil (venezuelano), Immanuel Wallerstein (estadunidense), Aníbal Quijano (peruano), através do grupo Modernidade/Colonialidade (1998), se quisermos localizar o pensamento de Ventura Profana em uma perspectiva mais ampla.

O grupo da modernidade/colonialidade tem encontrado inspiração num amplo número de fontes, desde as teorias críticas europeias e norte-americanas da modernidade, até o grupo sul-asiático dos estudos subalternos, a teoria feminista chicana, a teoria póscolonial e a filosofia africana; assim mesmo, muitos de seus membros têm operado numa perspectiva modificada de sistemas mundo. Sua principal força orientadora, contudo, é uma reflexão continuada sobre a realidade cultural e política latino-americana, incluindo o conhecimento subalternizado dos grupos explorados e oprimidos (ESCOBAR, 2003 p. 99) 
A assimetria nas relações de poder entre a Europa e os territórios colonizados representa uma dimensão constitutiva da noção de modernidade e, portanto, implica necessariamente na subalternização das práticas e subjetividades dos povos dominados. A subalternidade da maioria da população mundial se estabelece a partir de dois eixos estruturais, baseados no controle do trabalho e no controle da intersubjetividade, que se desdobram como a designação do eurocentrismo/ocidentalismo, na forma universalizante de produção de conhecimento e subjetividades na modernidade.

A decolonialidade é, em contrapartida, o pensamento que se desloca de uma ideia de mundo estabelecida a partir da perspectiva moderna e capitalista eurocentrada, e se abre para uma diversidade de vozes e caminhos. Trata-se da busca pelo direito à diferença e de uma abertura para um pensamento-outro. $O$ movimento faz uma intensa crítica à modernidade e à racionalidade, que foram imaginadas, até então, como experiências e produtos exclusivamente europeus. Nesse ponto estão, simultaneamente, o contato e a diferença entre as abordagens de Ventura Profana, artista, mulher, negra, trans, latino-americana; e Georges Bataille, filósofo, branco, cisgênero, burguês, europeu. Ventura tem sua produção artística inevitavelmente atravessada pelo trauma colonial, e busca, através do seu trabalho, resgatar a alteridade dos corpos subalternizados que foram - e ainda são dessubjetivados sistematicamente pelo projeto moderno.

A categoria "colonialidade do poder", proposta pelo sociólogo peruano Anibal Quijano, conceitualiza o padrão de dominação global que se constitui como a matriz de poder própria da modernidade, configurando-se com a conquista da América, no mesmo processo histórico em que tem início a interconexão mundial (globalidade) e a constituição dos modos de produção capitalista. Esses eventos produzem o surgimento de um sistema inédito de dominação e de exploração, que estruturam um sofisticado sistema de doutrinação cultural, controlando a produção e a reprodução de subjetividades, sob a égide do eurocentrismo e da racionalidade moderna. As religiões cristãs têm sido, historicamente, instrumentos a serviço do reiterado processo de colonização de territórios pela Europa, que impõe uma pretensa universalidade, submetida sempre à perspectiva eurocêntrica.

O que está no cerne do discurso de Ventura Profana não é apenas a ruptura com a chamada modernidade ocidental, mas a proposição de uma outra modernidade, que parta das especificidades de sua fala, e que esteja comprometida 
com a superação - ou ressignificação - do trauma colonial. Talvez Ventura esteja mais associada a uma "transmodernidade" (com a pertinência do prefixo), como defende o filósofo Enrique Dussel. A pós-modernidade, segundo Dussel, busca superar as questões negativas da modernidade, mas não quebra seu paradigma de centralidade da Europa. A transmodernidade, por outro lado, denuncia o discurso de totalidade e o encobrimento do outro. O outro que foi explorado e coisificado, e que serviu à razão instrumental do capitalismo enquanto sistema econômico, do liberalismo como sistema político, do eurocentrismo como ideologia, do machismo na erótica, do predomínio da etnia branca no racismo.

A partir do "trauma pentecostal" - que Ventura Profana compartilha de maneira elucidativa na conversa que está situada na parte final deste estudo -, a artista desenvolve sua pesquisa artística subvertendo a ortodoxia dos códigos evangélicos. De maneira propositiva, Ventura refunda um evangelho afirmativo de vida (e vida em abundância). Desobjetifcando seu corpo e valorizando sua subjetividade dissidente, a artista formula um novo perfil de congregação, no qual os sujeitos subalternizados, condenados à morte simbólica e física, transgridem essa negação através do sagrado, que Ihes permite viverem suas singularidades. 


\section{Considerações finais}

"Rompendo em Fé" é uma canção evangélica gravada pelo ministério de louvor da Comunidade Evangélica Internacional da Zona Sul, em 1997, que fez com que o grupo musical despontasse no segmento, sendo um dos pioneiros no louvor congregacional moderno. A música foi composta pelo pastor Marco Antonio Peixoto, líder da igreja fundada no bairro do Flamengo, na zona sul do Rio de Janeiro, e incluída em um álbum homônimo à música, gravado ao vivo na sede da congregação carioca. Na ocasião, a CEIZS recebeu Disco de Ouro e também o troféu da Associação Brasileira de Produtores de Disco (ABPD) - como a música gospel mais tocada nas rádios brasileiras. Depois disso, a canção se tornou um clássico, entoada desde então nas igrejas evangélicas de todo país.

O estrondoso sucesso da música "Rompendo em Fé", lançada na virada do século, se apresenta como um emblema da expansão e transformação das manifestações pentecostais em todo território nacional, motivado pelo crescimento das igrejas neopentecostais no Brasil. Desde, pelo menos, a segunda metade do século $\mathrm{XX}$, esse fenômeno religioso vem reconfigurando substancialmente aspectos políticos e socioculturais do país, se infiltrando em diversas áreas da agenda pública nacional. A apropriação da clássica canção gospel como título desta pesquisa acadêmica reflete não apenas o desejo de ressaltar os aspectos bem sucedidos do projeto de poder pentecostalista, mas, sobretudo, destacar a possibilidade de articular perspectivas transgressoras nas abordagens sobre esse movimento tão comumente associado ao fundamentalismo e à intolerância.

Não desconsidero nesse estudo a aproximação histórica e estrutural desses grupos religiosos emergentes aos tópicos mais conservadores da sociedade brasileira. Contudo, busco promover outras possibilidades de leituras sobre o fenômeno evangélico no Brasil, a partir da perspectiva dessacralizante, insubmissa e desestabilizante da arte contemporânea. A seleção de artistas, obras e projetos curatoriais que compõem essa investigação, colaboram para a constituição de possíveis conexões narrativas entre a história da arte brasileira e os símbolos e manifestações evangélicas, intersecção ainda escassa tanto nas produções artísticas, quanto nas curadorias e pesquisas acadêmicas. 
O desejo de ruptura é a força motriz do trabalho de Ventura Profana, artista em destaque nesta pesquisa justamente por seu posicionamento desobediente não apenas aos paradigmas cristãos, mas também provocador a outros ambientes normatizantes, como o próprio sistema institucional das artes e os cânones acadêmicos. Para elaborar seu evangelho TRANSgressor, Ventura incorpora (TAYLOR, 2013) em sua obra performática aspectos supercontemporâneos, onde a permeabilidade entre prática artística e vivência compõe uma narrativa ao mesmo tempo dialética e dialógica com os símbolos pentecostais.

"Romper em fé", no discurso da pastora travesti Ventura Profana, ganha dimensão polissêmica que transgride o próprio sentido motivacional original do louvor. "Com ousadia vou viver rompendo em fé", diz um dos versos do hino que batiza essa dissertação, e que ressoa, audaciosamente, na obra da artista através do rompimento com as noções coloniais destinadas aos corpos subalternizados: estigmas de gênero, raça, sexualidade, que são reafirmados sistemicamente por projetos de recalcamento das dissidências. Ventura propõe então a transgressão pela fé. Ou a fé pela transgressão.

Sem se propor a ser um panorama completo da abordagem dos emblemas evangélicos pela arte contemporânea brasileira, essa dissertação articula obras que trazem para seus cernes de discussão as implicações da crescente influência pentecostal na constituição de novas subjetividades no Brasil. Essa articulação se dá, especialmente- e intencionalmente -, a partir da perspectiva da relação dos sujeitos enunciadores, sejam eles autores, co-autores ou objetos das pesquisas sobre tais tópicos. Nesse sentido, sublinho também as contextualizações e pontuações autobiográficas no texto desse pesquisador que vos escreve.

Para compor essa narrativa heterogênea e crítica sobre as interseções da arte com os símbolos evangélicos, refuto a lógica do estranhamento ou da segregação que tanto caracterizam a relação entre as artes visuais, estudos acadêmicos e as manifestações pentecostais no Brasil. Com isso, me junto à recente geração de artistas, intelectuais e pesquisadores que, especialmente os oriundos de espaços populares/periféricos, abordam a influência dos símbolos evangélicos não como um mero interesse etnográfico ou antropológico, ou a partir de uma crítica esvaziada da expansão pentecostal brasileira, mas sim como investigação fundamental - e afetiva - para um olhar aprofundado sobre as reconfigurações de um país que insiste em subalternizar e exotizar as expressões 
culturais e estéticas que surgem no âmbito das camadas mais populares da sociedade.

Por se tratar de um tema em franca expansão e, portanto, em constante atualização, considero este estudo uma investigação preliminar, em progresso. Os próprios artistas aqui destacados continuam a produzir relevantes pesquisas e obras acerca dos tópicos pentecostais, em uma velocidade mais condizente com a dinâmica emergente evangélica do que uma pesquisa acadêmica é capaz de atender. De qualquer maneira, ainda que incipiente e inevitavelmente lacunar, espero contribuir com este estudo para a constituição de um repertório de reflexões sobre a candente relação entre as práticas artísticas e os símbolos pentecostais no Brasil. "Vou lutar e vencer / vou plantar e colher / a cada dia vou viver / rompendo em fé", diz os versos finais da canção supracitada. Expressões que se associam à Plantação de Traveco de Ventura Profana e que, de algum modo, refletem também o desejo dessa pesquisa: plantações de pensamento crítico para a colheita de práticas insubmissas contra quaisquer fundamentalismos. 


\section{Referências}

ARNOLD, Matthew. The Study of Poetry. In: The Portable Matthew Arnold. Nova York: Viking, 1949.

BATAILLE, Georges. O erotismo. Porto Alegre: L\&PM, 1987

O ânus solar. Lisboa. Hiena Editora., 1985.

.A experiência interior. São Paulo, Editora Ática, 1992.

BERGAMASCHI, Bárbara. Um dia da caça, outro do caçador. Janela de Cinema, Recife, 12 nov. 2017. Disponível em https: //bit.ly/2Zcv6bx. Acesso em: 15 maio 2018.

BÍBLIA, A. T. Provérbios. In BÍBLIA. Português. Sagrada Bíblia Católica: Antigo e Novo Testamentos. Tradução de José Simão. São Paulo: Sociedade Bíblica de Aparecida, 2008

BOAVENTURA, Jackson. A cor de catu. Belo Horizonte, Oi Kabum!, 2016.

BOSI, Alfredo. Dialética da Colonização. 3a ed., São Paulo: Companhia das Letras, 1995.

BOURDIEU, Pierre. As Regras da Arte. São Paulo: Companhia das Letras. 1996.

CAMPOS. Haroldo de. Metalinguagem \& Outras metas. São Paulo: Editora perspectiva. 1992.

COHEN, J. J. A cultura dos monstros: sete teses. In: COHEN, J. J. (Org.). Tradução de Tomaz Tadeu da Silva. Pedagogia dos monstros. Os prazeres e os perigos da confusão de fronteiras. Belo Horizonte: Autêntica, 2000.

CUNHA, Luiz Cláudio. Templos Eletrônicos - Os espertalhões da fé.Observatório da Imprensa, 10 Jan. 2012. 
DANTO, A. C. After the end of art: contemporary art and the pale of history. Princeton: Princeton University Press, 1997.

DANTO, Arthur. O Descredenciamento filosófico da arte. Trad. Rodrigo Duarte. Belo Horizonte: Autêntica Editora, 2014. p. 157, 159.

DANTO, Arthur. The Abuse of Beauty. Chicago: Open Court. 2003.

DELEUZE, G.; GUATTARI, F. O anti-Édipo - Capitalismo e esquizofrenia. Lisboa: Assírio \& Alvim, 2004.

DERRIDA, J. Foi etsavoir. Lesdeuxsources de la "religion" auxlimites de lasimpleraison.In: DERRIDA, J. \& VATTIMO, G. (dir.). La religion. Paris: Seuil, 1996.

DUSSEL, Enrique. Para una ética de laliberaciónlatinoamericana - v. I-II. Buenos Aires: SigloVeintiuno Editores, 1973.

ELIADE, Mircea. O Sagrado e o Profano; [tradução Rogério Fernandes]. São Paulo: Martins Fontes, 1992.

ESCOBAR, Arturo. Mundos y conocimientos de outro modo: el programa de investigación de modernidad/colonialidadelatinoamericano. Tabula Rasa, n. 1. Ene.-Dic. 2003.

FERREIRA da SILVA, Denise - A Dívida Impagável, São Paulo, 2019.

FOUCAULT, Michel. Prefácio à transgressão. Estética - Literatura e Pintura, Música e Cinema - Col. Ditos \& Escritos III, 2015.

GUMBRECHT, H.U. Corpo e forma: ensaios para uma crítica não hermenêutica. Rio de Janeiro, EdUERJ, 1998.

HALL, Stuart. A centralidade da cultura: notas sobre as revoluções de nosso tempo. Educação \& Realidade. v. 22, n. 2. jul./dez. 1997. 
HAUSER, A. Teorias da arte. 2. ed. Lisboa: Editorial Presença, 1988.

HEINICH, Nathalie. Práticas da Arte Contemporânea: uma abordagem pragmática a um novo paradigma artístico. Revista Sociologia \& Antropologia, v. 04, n. 02, pp. 373-390. 2004.

HERVIEU-LÉGER, Danièle. La religionpourmemoire.Paris :Cerf, 1993.

KAUFMANN, Fritz. Arte e Religião. Revista da Abordagem Gestáltica PhenomenologicalStudies - XIX(2): 243-246, jul-dez, 2013.

LIPOVETSKY, Gilles. A felicidade paradoxal: ensaios sobre a sociedade de hiperconsumo. SP: Companhia das Letras, 2007.

MALLARMÉ, Stephan. MessagePoétiqueduSymbolisme. Paris: Nizet, 1947.

MARIANO, Ricardo. Expansão pentecostal no Brasil: o caso da Igreja Universal. Estud. av. vol.18 n.52. São Paulo set/dez. 2004.

MARTINS, José de Souza. O poder do atraso; ensaios de sociologia da história lenta. São Paulo, Hucitec, 1999.

MIGNOLO, Walter. Histórias Globais/projetos Locais. Colonialidade, saberes subalternos e pensamento liminar. Belo Horizonte: Editora UFMG, 2003.

MIGNOLO, Walter. Histórias Globais/projetos Locais. Colonialidade, saberes subalternos e pensamento liminar. Belo Horizonte: Editora UFMG, 2003.

MOMBAÇA, Jota. Pode um cu mestiço falar? Medium. 2015. Disponível em https://medium.com/@jotamombaca/pode-um-cu-mestico-falar-e915ed9c61ee.

MONTERO, Paula. Secularização e espaço público: a reinvenção do pluralismo religioso no Brasil. Revista Etnográfica, vol. 13, n. 1: 7-16. 2009 
NASCIMENTO, Cleoneide Moura. "Fala que eu te escuto" Espetáculo Universal da Fé. Tese de qualificação de doutorado: programa de Pós-Graduação em sociologia do centro de ciências humanas, letras e arte. UFPB. 2012.

NAZÁRIO, Luiz. Da natureza dos monstros. São Paulo: Arte \& ciência, 1998.

NEGRÃO, Lísias Nogueira, "Intervenção", in Alberto Moreira e Renée Zicman (orgs.), Misticismo e novas religiões, Petrópolis, Vozes/USF/FAN, pp. 130-135, 1994.

NOGUEIRA, Thyago. Corpo a corpo: a disputa das imagens, da fotografia à transmissão ao vivo. Rio de Janeiro: Ed. IMS, 2017.

PEQUENO, Fernanda. Georges Bataille, o olho e a economia: a arte como despesa improdutiva. Concinnitas. 2014.

QUIJANO, Anibal. Colonialidade do poder, eurocentrismo e América Latina. In: Lander, Edgardo (Org.). A colonialidade do saber: eurocentrismo e ciências sociais. Perspectivas latino-americana, p. 227-278. Buenos Aires: Clacso, 2005.

RANCIÈRE, Jacques. A partilha do sensível. Estética e política. Tradução de Mônica Costa Netto. São Paulo: Editora 34, 2000.

ROCHA, Cássio Bruno Araújo. Um pequeno guia ao pensamento aos conceitos e à obra de Judith Butler. Cad. Pagu, Campinas, n. 43, p. 507-516, Dec. 2014.

SILVA, Vagner Gonçalves da (org.). Intolerância Religiosa: impactos do neopentecostalismo no campo religioso afro-brasileiro. São Paulo: Editora daUniversidade de São Paulo, 2007, 328pp.

SONTAG, Susan. Contra a Interpretação. Trad. Ana Maria Capovilla. Porto Alegre: L\&PM, 1987. 
TAYLOR, Diana. O Arquivo e o repertório. Performance e memória cultural nas Américas. Tradução de Eliana Lourenço de Lima Reis. Belo Horizonte: Editora UFMG, 2013.

TOURAINE. Alain. Crítica da Modernidade.Petrópolis: Vozes, 1994.

TROELTSCH, Ernst. Protestantism and Progress: The Significance of Protestantism for the Rise of the Modern World. Philadelphia: Fortress, 1986, pp. 23-27.

WEBER, M. A ética protestante e o espírito do capitalismo.São Paulo, Cengage Learning, 2009.

WEBER, Max. A Política como Vocação. In: WEBER, Max. Ciência e Política, Duas Vocações. São Paulo: Editora Cultrix, 1996.

WOODWARD, Kathleen. Identidade e diferença: uma introdução teórica e conceitual. In: SILVA. Tomaz Tadeu da (org). Identidade e diferença: a perspectiva dos estudos culturais. 3aㅡ ed. Petrópolis, RJ: Vozes, 2004. 


\section{LINKS INTERNET}

https://www1.folha.uol.com.br/fsp/cotidian/ff2301200612.htm

https://www.guerreirododivinoamor.com/

https://www.youtube.com/watch?v=80mlglxrsZA (entrevista de bárbara Wagner na Escola de Cidade)

https://www.em.com.br/app/noticia/cultura/2019/09/18/interna_cultura,1085909/artist as-da-mostra-que-foi-suspensa-no-map-contam-como-sao-suas-obras.shtml

https://www1.folha.uol.com.br/fsp/cotidian/ff2301200612.htm

https://www.guerreirododivinoamor.com/

https://www.youtube.com/watch?v=80mlglxrsZA (entrevista de bárbara Wagner na Escola de Cidade)

https://www.em.com.br/app/noticia/cultura/2019/09/18/interna_cultura,1085909/artist as-da-mostra-que-foi-suspensa-no-map-contam-como-sao-suas-obras.shtml

https://www.premiopipa.com/2020/10/ocupacao-finalistas-2020-maxwell-alexandre/

https://www.premiopipa.com/wp-content/uploads/2019/04/Texto-de-Kiki-

Mazzucchelli.pdf 


\section{Anexo}

Entrevista feita com Ventura Profana em junho de 2019.

\section{Quem é Ventura Profana?}

Sou Ventura, nasci em Salvador, me criei em Catu. Venho de uma família extremamente cristã, de uma linhagem Batista. Me mudo pro Rio de Janeiro aos 11 anos. E aí no Rio eu comecei a congregar na Igreja Cristã de Nova Vida, em Olaria. Saio da igreja aos 18 , e dois anos depois eu começo a tecer um trabalho pensando no meu corpo, na beleza do meu corpo, da dissidência, da monstruosidade, me reconhecendo como um corpo trans, um corpo monstro. E nesse processo de evidenciar, e de conseguir registrar e destacar a beleza do meu corpo e a beleza das minas curvas... Mas eu comecei a fazer isso registrando minha bunda. $E$ isso ficou bem marcado. Eu fiquei maior tempão só nesse registro e nessa relação da minha bunda em vários espaços, invadindo vários lugares do Rio. E aí em 2016 eu desenvolvo com a Jonathan Vicente o Reino das Bichas, junto com a minha (obra) Universal é o Reino das Bichas, que é calcinha que eu faço com a logo da (igreja) Universal. E aí 2016 foi o ano que meu trabalho começou a ganhar mais consistência. É o ano que eu mudo de nome, é o ano que eu conheço todas as bichas da cidade, começo a me relacionar com as bichas, e começo a me relacionar com as travestis, e começo a frequentar a noite, viver na madruga, levar porrada, cair na porrada com bofe...e, enfim, e o ano que eu começo a passar pelos processos de transformação e de renuncia às masculinidade e as normatividades todas que são impostas. E junto disso é quando eu começo a pesquisar a fundo as manifestações neopentecostais, em todas as instancias que elas são e existem. Eu comecei a fazer um levantamento de roupas de coreografias, de tipo look... Aí pensando muito a moda "fashion crente", o lugar da mulher cristã, e como essa mulher cristã se coloca, se veste, se comporta, mas também pensando muito no espetáculo dentro da igreja e pensando em como a igreja supre - de forma proposital - uma carência deixada pelo estado de entretenimento e cultura em periferias. Então, por exemplo, onde deveria ter um cinema, de repente uma igreja toma conta, uma igreja invade esse espaço, deixa de ter um cinema para ter uma igreja. Onde deveria ter um teatro... não se tem um teatro acessível. $O$ teatro mais 
próximo da Zona Norte, do Complexo do Alemão, é, por exemplo, no Norte Shopping, que tem uma programação péssima, super destacada, que subestima 0 gosto e a sensibilidade do pobre, do preto, o favelado... E daí a igreja entra em um lugar ofertando tudo isso. $E$, além dela ofertar tudo isso, ela te oferece a participação. Ela te insere no lugar do fazer. Então, você pode cantar, você pode atuar, você pode dançar, você pode assumir um lugar de liderança, que te é negado "all the time", em todos os espaços... Então você deixa de ser "sub"... Então, aí, enfim, e uma questão muito mais complexa, porque a maneira como o cristianismo é desenhado pro Brasil, sobretudo, há 120 anos atrás, com a vinda dos missionários americanos pra cá... é babado! Para mim é muito mais complexo do que só essa coisa do show...

\section{Quando você começou a considerar que o quê você fazia era um trabalho de arte?}

Eu nasci para ser artista. Sempre lutei pra ser. Eu acho que hoje... Ou melhor, hoje eu nego esse lugar... quer dizer, acho ótimo ser artista, "muito bem, obrigada", quero o "aqué" do artista, quero ser paga pelo meu trabalho artístico, quero dinheiro pra produzir, quero ser paga, sei lá, por respirar. Por que, sei lá, o meu corpo é muito sagrado, nesse sentido. Quando eu invado qualquer espaço de arte, eu dou meu nome. $E$ aí é isso: eu acho que só a presença do meu corpo nesse espaço de arte já diz muita coisa. E ele já coloca muita coisa em cheque, em questionamento. Mas, assim, o meu desejo, o meu coração, não está mais nesse lugar de querer ser artista. Que já foi. Ate por que eu já sou. Mas teve algum momento específico que você tenha percebido que esse seu interesse em pesquisar a cultura neopentecostal poderia ser um trabalho de arte?Assim, comigo foi mais uma coisa no sentido de perceber que eu precisaria falar sobre isso para poder atravessar e ultrapassar minha própria cruz, independente da arte ou não. Ou independente do que caberia... ou, enfim, eu não me importei tanto com a arte, eu me importei mais comigo, mais com meu processo enquanto alguém que cria, que precisa criar para poder dissolver e resolver questões em mim, que são muito pesadas e são muito violentas. Então, eu acho que a igreja e a minha trajetória cristã foi inteira violenta, foi inteira agressiva, ela me castrou em diversas instâncias, e, à medida que eu almejava um lugar de liberdade - inclusive liberdade de criação -, eu precisei 
investigar e precisei me reconectar com essa herança, essa memória cristã evangélica, na minha vida. Mas, assim, foi também quando eu percebi que essa era minha maior força. Eu percebi que o meu diferencial era também o que me emocionava de fato, que me fazia tocar o sobrenatural era lidando com essas questões, era trazendo de volta toda essa carga, essa memória cristã neopentecostal para perto de mim.

Você é artista negra, periférica cristã e travesti. De que tipo de associação você acha possível fazer com o movimento neopentecostal, considerando que, de maneira geral, estes ambientes são considerados hostis aos grupos que não se encaixam aos padrões tradicionais cristãos?

A vivência neopentecostal é quase sempre racista (quase sempre, assim, para não falar o tempo todo), ele é sempre misógina, ela é sempre transfóbica e ela é sempre xenofóbica. Isso "all the time". Eu consigo identificar várias "não-coincidências", várias referências, inclusive bíblicas... Você vai ver, por exemplo, Paulo... Quem é Paulo? De onde Paulo vem? O que quê Paulo faz? Paulo escreve, sei lá, metade do Novo Testamento, e Paulo é Romano, ou seja, Paulo é Europeu. Então quem tá doutrinando todo esse povo, a raiz dessa doutrina é eurocêntrica. $E$ aí os padrões que tem sido impostos são eurocêntricos. A gente tá falando de uma realidade colonial, de um país que é assolado por um projeto de poder de dominações coloniais. E o cristianismo desde sempre foi uma estratégia de guerra, um braço, para poder controlar e conduzir esse povo colonizado.

\section{Então, nesse sentido, o cristianismo serve a esse plano de dominação?}

Sim. Você percebe que em todos os territórios onde o capitalismo, onde as nações capitalistas soberanas entram para tomar posse, para invadir, elas entram com o cristianismo como braço. Isso aconteceu na China, em alguns países de África, no Caribe, em vários lugares... Só que no Brasil acontece um fenômeno (por que tudo aqui no Brasil é meio fenômeno, né?!). Você vai ver que toda essa galera: os pretos, os indígenas, os nordestinos, essa galera toda... A branquitude ela é muito sacana, então ela traz o "presentinho" dela, a história dela, a cultura dela, a fé, a maneira de conduzir o corpo, de conduzir a vida, seguindo o que é santo, o que é bom... Aí ela 
vai roubar nossa espiritualidade, que é nossa de raiz, ela toma das nossas mãos. A festa de lemanjá, do dois de fevereiro na Bahia, quando você vai ver os terreiros de candomblé na Bahia... Todos brancos! As casas de Umbanda... todas tomadas por uma população branca! $E$ as pessoas pretas nas igrejas. Então, interessa à branquitude, para o homem branco, que o preto esteja afastado do seu centro de nutrição máxima de poder, de sua própria fé, sua própria história.

Considerando isto, porque você decidiu se associar a uma religião cristã e não, por exemplo, a uma religião de matriz africana?

Por que eu preciso resolver o que me foi dado na minha vida. Tipo assim, para mim (babado!), eu tenho maior admiração do mundo, tenho maior necessidade, pelo axé e, enfim, pela fé preta, mas... Eu, Ventura Profana, preciso resolver questões com o cristianismo. Eu acho que é uma missão. Por que eu preciso me comunicar com minha família. Eu preciso arrancar as vendas dos olhos da minha mãe, do meu pai. Eu preciso salvar minha família de um vírus. E para isso eu só consigo lidando com o veneno. Eu preciso produzir esse antídoto. E eu não consigo produzir esse antídoto com outra substância. Eu preciso recorrer ao veneno que me foi injetado.

Como que você vê, atualmente, as possibilidades de relação entre arte e religião? Você acha que é possível produzir uma arte transgressora sob influência de um ambiente religioso?

Eu acho que a arte é um terreno que precisa ser tomado. E, assim, eu me importo com a arte até o ponto que eu perceber que ela tá me pagando. No momento que ela não tiver me pagando, eu quero que ela se foda! E aí, o se foda é assim: se o Bolsonaro quiser fechar museu, bebê, que se foda. Por que se for para a branquitude continuar assumindo esses espaços e recebendo desses espaços, e "as corpas" dissidentes, pretas, indígenas, travas, continuarem indo naqueles espaços sem receber nada, sendo a alma desses lugares e sendo pessimamente remunerados, então eu prefiro que esses espaços acabem. E eu não vou sentir nem saudade. Se for para continuar fazendo ode a Oswald de Andrade e Tarsila do Amaral e não reconhecer a importância do trabalho artístico da Bianca Kalutor, da Jup do Bairro, ou de Luciana Vasconcelos, ou da minha mãe, ou do meu pai, sei 
lá... Se não tiver aberto a essa galera, se não vai pagar bem essa galera... então que ele se exploda. Por que se for pra ficar consagrando a branquitude, eu prefiro mil vezes a igreja. Que se foda! Vira igreja! Eu não tenho medo.

\section{Como que o sagrado se manifesta em sua obra?}

Na manifestação do espírito de vida. Eu acho que meu trabalho todo é fruto de uma tentativa de viver em equilíbrio, em um relacionamento de amor e de temor por um espirito de vida que é poderoso, que me possibilita me santificar.

\section{E o seu trabalho tem um desejo de ser o lugar onde você consegue expressar isso?}

Acho que meu trabalho é um canal. Existem vidas que precisam ser tocadas. Tem uma coisa que se chama evangelho que precisa ser espalhado. E hoje eu sei que eu sou uma missionária, eu tenho uma missão. Eu sou uma travesti evangelista. Eu tenho uma boa nova de vida para espalhar. E eu só consigo estar plena para espalhar essa boa nova por que eu sou movida e sustentada por esse espírito de vida. Então, ele me invade, ele vem de diversas formas. Por que meu trabalho se dá em vários suportes. Eu canto, eu performo, eu sou colagista, eu escrevo, eu agora tenho feito uma linha mais objetual e tal. Então, assim, para que tudo isso aconteça eu preciso estar conectada com esse espírito de vida. Que eu não acredito que esse espírito seja santo. Se ele for alguma coisa, ele vai ser profano.

Falando em espírito de vida... como a morte aparece no seu trabalho?

A morte não aparece no meu trabalho! A morte aparece na vida como ela é. A morte ela tá dada. Ela aparece por que ontem uma amiga minha foi morta.

Mas se você trata de vida, você trata de morte...

Mas eu não gosto... sei lá! Lá em 2016 eu tinha uma questão com a morte que precisava ser resolvida... Quando a gente tá falando de Brasil, quando a gente tá falando de população trans, de mulher, de preto no Brasil, a gente vai falar de 
morte. Não tem como. A gente já parte daí, do "vale de ossos secos". Para mim há uma condenação. Eu acho que a gente (travestis) rompe com essa condenação. Existem trabalhos de negação e de luta, assim... Babado! Luta de travesti, batendo na cara da morte e dizendo: "querida, morre antes tu, mas eu não morro!". Então tem um fight. Então é uma condenação por que você já nasce condenado. Preto já nasce condenado. A estrutura conspira, ela está imposta contra nossos corpos como condenação. E isso a bíblia mesmo fala. $E$ aí eu penso que Evangelho é justamente boa nova. Esse é o legado maior da figura de Jesus Cristo. E é por isso que eu sou uma evangelista. Eu tenho trazido uma boa nova de vida para corpos que são condenados pelo mundo.

\section{Como que você pratica sua espiritualidade? Você acredita que há em suas obras aspectos espirituais?}

Essa é uma grande questão. Por que o meu trabalho começou a ganhar uma grande responsabilidade. Sei lá, já cantei para mais de 400 pessoas. No palco do Circo Voador, ou num grande teatro em Belo Horizonte, ou numa grande festa de rua em São Paulo. Quando você fala para muita gente, você tem uma grande responsabilidade com a mensagem que você está trazendo. Então, eu não curto me sentir hipócrita. Então eu tive que mudar minha vida por conta desse meu trabalho. Eu tive que... nem sei, assim. Muita coisa precisou ser transformada por que quando você assume o compromisso de falar de vida e tem uma conduta autodestrutiva para mim não funciona, não bate. Por que as pessoas vão ver que não bate. Eu preciso ser testemunho de vida para minhas amigas. Eu quero viver e tenho tecido a minha vida na fé da abundância, na fé da prosperidade, na fé da plenitude de vida, então por isso eu precisei mudar. E aí, sim, quando você faz as coisas guiada por esse espírito de vida, esse espírito de vida se manifesta em você e fala para outras pessoas.

\section{Esse é o aspecto espiritual do seu trabalho então?}

Sim. A branquitude é muito medíocre. Então, há uma cultura de suicídio, de depressão, de morte, transformada em fetiche, em algo cool, em algo desejável, algo glamuroso... Bem Lana Del Ray, sabe?! Aí a gente cresce iludida, acreditando 
que cortar os pulsos é bacana, cinematográfico. Daí as "gatas" vão indo por esse caminho. Eu não acho que é isso. Eu acho que nós que somos corpos perseguidas, que temos sido caladas, a gente precisa ter amor pela vida. A gente precisa lugar umas pela vida das outras. Lutar umas pelas velhices das outras. Eu quero ver travas velhas! Eu quero ser uma trava velha! Eu quero vida eterna para as minhas. E isso é uma questão espiritual. Isso só vai ser resolvido pelo plano espiritual, por que a condenação é espiritual. Por que a batalha é espiritual. É uma guerra física, emocional, mas ela é, sobretudo, espiritual.

\section{O que significa transgressão para você? Em quais aspectos o seu trabalho artístico pode ser considerado transgressor? Ou o que você almeja transgredir com suas proposições?}

Olha, se a gente for recortando... a gente prega o "gressão" de progressão e mistura com "trans" delas e, daí, transgredir talvez seja esse avanço, na transcendência, no trânsito, na travessia... e aí, eu acho que a gente tá transgredindo desde sempre. A travesti ela é transgressora desde sempre. Mesmo que ela não queira. É uma coisa natural. Eu tenho consciência que para muitos corpos o meu corpo vai ser um corpo transgressor. Mas para mim não. Eu estou só fazendo o mínimo. E eu estou fazendo só por que precisa ser feito. Não por que eu queira chocar, ou ser vanguardista. Eu tenho feito por que é necessário.

Como você acha que o aspecto erótico é desenvolvido em seu trabalho? Quais são as especificidades de se falar sobre o corpo e a sexualidade travesti, no contexto das artes contemporâneas, e disputando os códigos neopentecostais?

A religião sempre vai se voltar o corpo para aquilo que a interessa, ou pra sacramentar algumas ideias. E o próprio erotismo está dentro da construção da religião, em todo tempo. Mesmo quando a gente vai lá na base católica, e na maneira como a fé, o sacrifício é retratado, isso é colocado de maneira erótica. Daí, quando isso é trazido do contexto neopentecostal, as castrações 
dos corpos se dão de maneira mais violenta. Bem sexista. E os símbolos e os gestos são programados de maneira mais severa. E aí, naturalmente, a resposta a esses tabus, a esses desejos, essas manifestações veladas, elas tendem a ser mais intensas. Eu acho que meu corpo, por ser um corpo travesti, um corpo preto, já é lido de maneira violenta. Já é lido de maneira agressiva. Então, toda vida eu lidei com essa agressividade. E eu sou gigantesca, imensa... Então meu próprio corpo me trazem umas "questões de fábrica" para serem resolvidas. E aí, na arte contemporânea, a discussão está partindo muito de "que corpo é esse que tá propondo?". Então, primeiro, meu corpo é ponto-chave para isso. Para onde eu quero que essa discussão parta? Para mim, eu quero que parta do meu cu. Que parta do maior tabu. Quero que parta da minha bunda. Para mim, partiu da observação disso: de como meu corpo era recebido pelo mundo, de quem despejava o afeto, de onde vinha o "coió", de onde vinha... Isso tudo faz parte de como eu me relaciono com meu trabalho e minha fé.

\section{Você acha então que o erotismo aparece no seu trabalho como uma estratégia...}

Meu trabalho começou por que eu queria provar a minha beleza e a minha sensualidade. Meu trabalho só começou por conta disso.

\section{E quando você começou a associar religião e erotismo em seu trabalho?}

O lugar do trabalho que fica mais sublinhado essa associação de religião e erotismo é na minha escrita. Eu acho que a minha escrita é bastante erótica. Mas, pelo fato de eu ser uma travesti, e da travestir estar vinculada à realidade sexual e aos tabus sexuais (95\% das gatas estão lançadas no campo da prostituição), inevitavelmente você está se relacionando com o sexo, com a objetificação do seu corpo. Então, da mesma maneira que para arte eu sou um objeto, para a arte eu também sou um objeto. Então eu me assumi artisticamente como um corpo a venda, como uma puta vende seu corpo. Daí é isso, eu assumo os lucros e os prejuízos desse corpo no mercado. E eu acho que essa é uma maneira muito inteligente de sabotar o próprio sistema. Por que ao invés do lucro estar indo para o sistema, está vindo para minha mão. E tá tudo junto, né?! Os pastores estão sendo denunciados por estupro, as 
"gatas" estão dando o cu para não dar a buceta, fingindo virgindade para a família... Então, tipo assim, não tem como, o sexo é pilar da sociedade. Ele vai sempre se manifestar. Seja por muito dar, ou por nada fazer. 